\title{
A REVIEW OF THE FISHES AND FISHERIES OF MINAS BASIN AND MINAS PASSAGE, NOVA SCOTIA, AND THEIR POTENTIAL RISK FROM TIDAL POWER DEVELOPMENT
}

\author{
MICHAEL J. DADSWELL ${ }^{1 *}$ AND ROGER A. RULIFSON ${ }^{2}$ \\ ${ }^{I}$ Department of Biology, Acadia University, \\ Wolfville, NS B4P 2 R6 \\ ${ }^{2}$ Department of Biology, East Carolina University, \\ Greenville, NC 27858 USA
}

\begin{abstract}
A total of 85 species of fish are known or suspected from Minas Basin and Minas Passage, Nova Scotia, Canada. This systematic review details their seasonal occurrence, habitat, abundance, migratory behavior, fisheries and potential impact from tidal power development. The fish assemblage is a mixture of species common to the Bay of Fundy and the Atlantic coast of Nova Scotia as well as numerous warm- and cold-water visitors seldom found elsewhere in Canada. Minas Basin fisheries exploit some species especially those that migrate through the Basin during summer. Fishes were captured or observed using angling, seines, benthic long lines, drift and fixed gill nets, intertidal fish weirs, bottom trawls and sightings while on vessels. Fishes are categorized with respect to their taxonomic diversity, seasonal occurrence, status, fisheries and the potential impact from tidal lagoons and propeller turbines resulting from development of tidal power in Minas Basin and Minas Passage.

Keywords: Bay of Fundy, habitat, species status, propeller turbines, taxonomic relationship, tidal lagoons.
\end{abstract}

\section{INTRODUCTION}

The objective of this review was to identify the diversity and seasonal occurrence of fishes in Minas Basin and Minas Passage for their habitat, abundance, migratory behavior, fisheries and their potential interaction with tidal power development projects. The annotated list and comments were compiled from published research sources available since the 1800's as well as the observations of local fishers and the personal observations of the authors

* Author to whom correspondence should be addressed: mike.dadswell@acadiau.ca 
based on their fisheries research in Minas Basin and Minas Passage since 1981. Additional sources include publications on the marine fishes of Atlantic Canada, those for different regions of the Bay of Fundy and its tributaries, as well as unpublished research works many of which are Honours, Masters and $\mathrm{PhD}$ theses completed at Acadia University, East Carolina University, Dalhousie University and the University of New Brunswick.

A need for this review exists because of the potential for open ocean tidal power development in Minas Basin and Minas Passage using tidal lagoons (Cornett et al. 2013) or open-stream hydrokinetic devices (Gill 2005, AECOM 2009, FORCE 2017). Minas Basin is a highly productive, summer warm marine embayment important to the biology of many fish species (Dadswell et al. 1984a, Rulifson and Dadswell 1995, Campana et al. 2008, Kendall et al. 2018) and Minas Passage is the conduit through which large numbers of fishes pass annually on their way into and out Minas Basin while migrating around the Bay of Fundy (Dadswell et al. 1984b, Stokesbury et al. 2016). The fishes apparently have little choice in this migration pattern since their migratory cue is the signal from the residual current structure of the Bay of Fundy which they follow along the coast (Dadswell et al. 1984b, Dadswell et al. 1987). Potential mortality from tidal power development in Minas Passage or Minas Basin may seriously impact designated species-at-risk (Amiro et al. 2003, Campana 2007), the diversity and abundance of fishes occurring in the region, and the productivity of local and distant fisheries (Dadswell et al. 1987, Rulifson et al. 2008, Dadswell et al. 2017, Dadswell et al. 2020, Rulifson and Dadswell, in press).

\section{SOURCES OF DATA}

Leim and Scott (1966) compiled approximately 60 years of observations on marine fishes of Atlantic Canada resulting from the fisheries work at the Biological Station, St. Andrews, NB. Their book includes considerable specific references to the populations of fishes found in the Bay of Fundy and Minas Basin and is often more complete than Scott and Scott (1988), which is lacking some of the local detail available in the earlier work. Scott and Scott (1988) is excellent with respect to the up-to-date taxonomy of Atlantic 
fishes, their biology and North Atlantic distribution. The systematic arrangement in our annotated work is based on www.fishbase.org.

Perley (1852) was the first to describe the fish and fisheries of the inner Bay of Fundy (iBoF). His observations form the baseline to which later works can be compared. Huntsman (1922) was the first modern work on the fishes of the inner Bay of Fundy and and Leim (1924) provided details on fishes captured in intertidal fish weirs in Minas Basin. Bousfield and Leim (1959) provided additional information on the fishes of Minas Basin and Bleakney and McAllister (1973) described the fishes that were stranded by extreme low tides at Kingsport in Minas Basin. Dadswell and coworkers (1984a, 1984b) detailed seven years of study on the iBoF including Cumberland Basin and Minas Basin and sampling using drift gill nets $(6.0 \mathrm{~cm}-14.0 \mathrm{~cm}$ stretched mesh), drags (5.0 and $12.7 \mathrm{~cm}$ stretched mesh) and mid water trawls $(5.0 \mathrm{~cm}$ stretched mesh), shore seines and intertidal weirs. Rulifson and co-workers (1987, 2008) studied the fishes captured in weirs along the north shore of Minas Basin. Wehrell (2005) surveyed fishes captured by a rock hopper trawl (a specialized 'Yankee 35' with $12.7 \mathrm{~cm}$ stretched mesh) from June to September in the southern Bight of Minas Basin and Scots Bay. Baker and co-workers (2014) detailed the fish captures in two weirs, one on the north side and one on the south side of Minas Basin during 2013. Dadswell et al. (2020) examined fish catches on every low tide during April-July 2017 from a weir at Bramber on the south shore of Minas Basin (Fig 1). Students at the Estuarine Centre of Acadia University have conducted numerous studies on fishes under the direction of G. Daborn, M. Stokesbury and A. Redden during 1973-2018. Dyer and co-workers (2005) and FORCE $(2009,2017)$ examined the fisheries from Minas Channel, Minas Passage and Minas Basin.

Fisheries and Oceans Canada (DFO) has or had annual stock assessment cruises and ichthyoplankton surveys in the Bay of Fundy since 1970 (Scott 1987, Scott 1988, Simon and Comeau 1994) using a 'Western' IIA bottom trawl of $12.7 \mathrm{~cm}$ stretched mesh with a $2.0 \mathrm{~cm}$ mesh cod-end liner and with 330 um 'bongo' plankton nets. There are approximately 22 stations occupied in the Bay of Fundy from Scots Bay to the Lurcher Shoal region. Unfortunately, the stations only go as far as Minas Channel and there are none in 


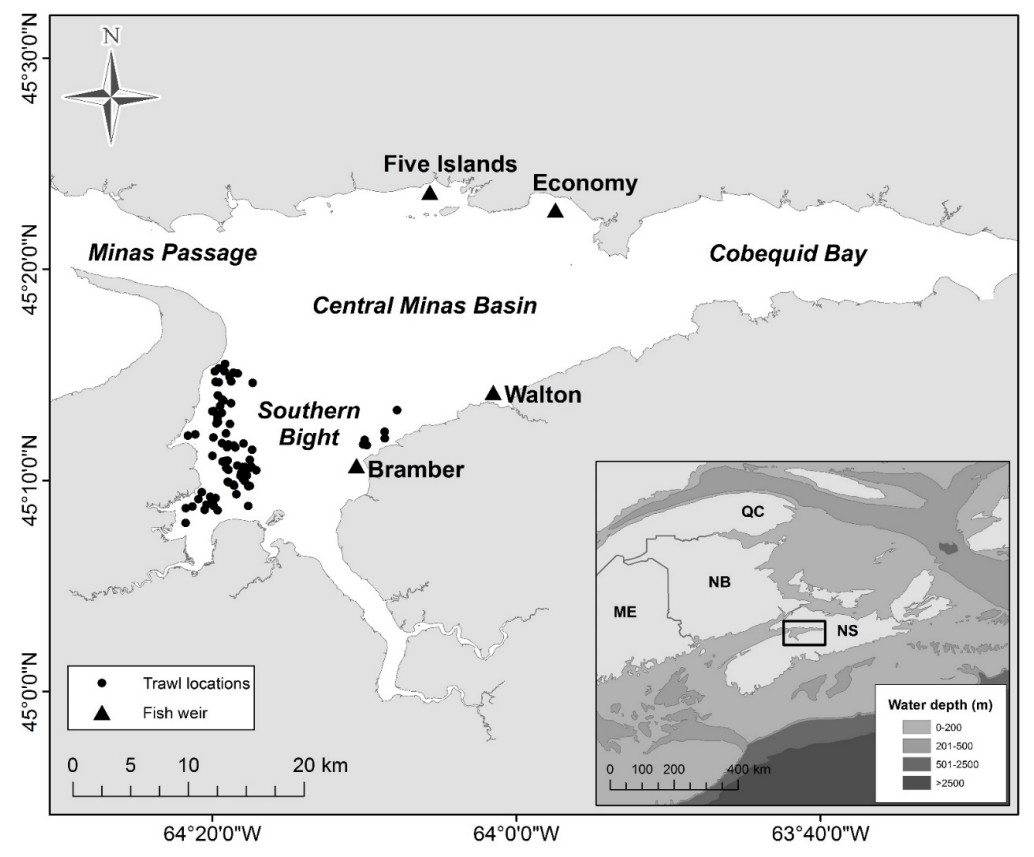

Fig 1 Minas Basin and Minas Passage in the inner Bay of Fundy. Minas Basin consists of four regions: central Minas Basin proper, Cobequid Bay the eastern section inside Economy Point, the Southern Bight, and Minas Passage which connects Minas Basin to the Bay of Fundy. Triangles represent intertidal weirs where scientific studies have been carried out since 1982. Dots represent trawling locations using a Rock-Hopper trawl during sampling with commercial flounder fishers.

Minas Passage or Minas Basin. All captured fishes are identified, enumerated, measured and weighed and physical oceanographic variables measured (temperature, salinity and substrate).

Based on the number of studies and the similarity of resulting fish captures, the fish occurring in the Bay of Fundy and Minas Basin are now well known. The fishes of Minas Basin and Minas Passage consist of marine and diadromous species. There are a high proportion of coastal migrant, warm water species from populations as far south as Florida (Fig 2, Dadswell et al. 1987, Rulifson et al. 2008, Dadswell et al. 2016) as well as species from the Gulf of Maine and the Scotian Shelf (MacDonald et al. 1984, Scott and Scott 1988) and the Gulf of Saint Lawrence (Saunders 1969). Unfortunately, there have been very few directed fish studies within Minas Passage itself except for surveys of herring larvae (Koeller 1979, Bradford and 


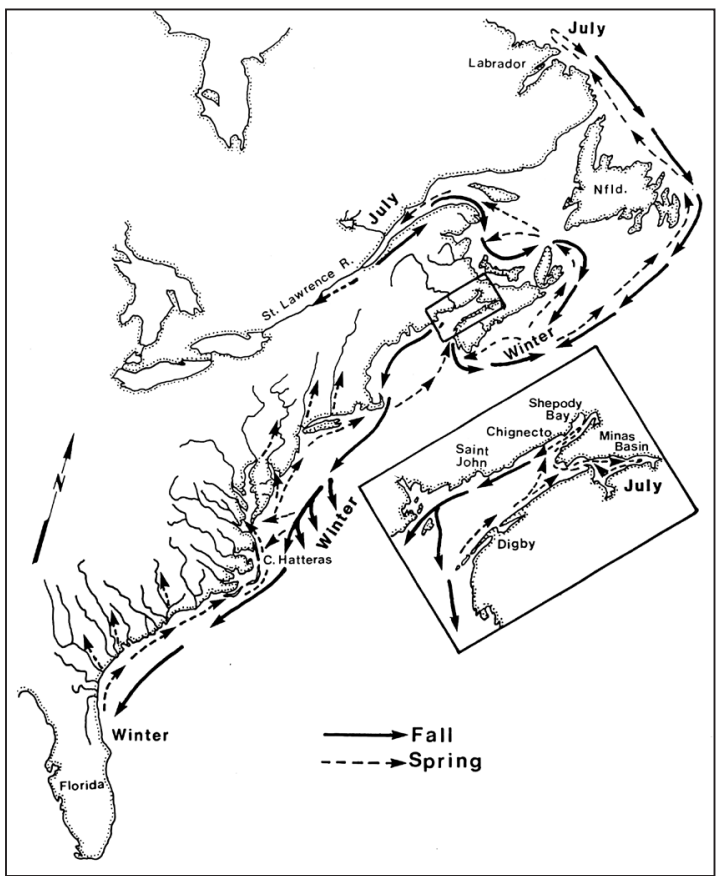

Fig 2 General migration pattern and terminus points for American shad on the Atlantic coast of North America based on 968 returns from 21,330 uniquely numbered spaghetti tags. Tags were deployed in Minas and Cumberland Basins in the inner Bay of Fundy during 1979-1984 and tag returns were received from 1980-1989.

Iles 1993), a brief pelagic trawl survey (FORCE 2010) and a series of studies on selected, acoustically tagged species in the area of the Fundy Ocean Research for Energy (FORCE) tidal turbine test site (Redden et al. 2014, Keyser et al. 2016) and the Ocean Tracking Network (OTN) acoustic receiver line deployed across the Passage (Stokesbury et al. 2016).

The exploitation of tidal power for hydroelectricity from Minas Passage has become possible since the development of instream hydro-kinetic devices consisting of a wide range of potential designs (Gill 2005, Karsten et al. 2008). Some designs are axial flow, hydraulic-lift propeller turbines similar in operation to those found in rivers and estuaries. These turbines have moving blades that can cause mechanical damage to fishes passing through the turbine draft tube (Von Raben 1957, Dadswell and Rulifson 1994, Hammer et al. 2015, Dadswell et al. 2018). Inside the turbine draft tube there are 
also changes to the pressure and velocity of the water passing over the turbine blades that can cause fish mortalities from shear, pressure flux or cavitation (Dadswell and Rulifson 1994, Deng et al. 2005, Buckland et al. 2013, Zangiabadi et al. 2016). In 2018 Cape Sharp Tidal Power Venture installed a 10 blade, $16 \mathrm{~m}$ diameter propeller tidal turbine in Minas Passage that was proposed to develop $2 \mathrm{MW}$ of power (Cape Sharp Tidal 2018). Unfortunately, the turbine broke down soon after deployment. Other devices in use or in planning stages function like wind turbines or eggbeaters (FORCE 2017). Their impact on fishes has been little studied but may be less than from propeller turbines (Viehman and Zydlewski 2015). Still others have no moving parts in the water and produce electricity through the force of the tide on a large, floating kinetic keel (Big Moon Power 2018). This device appears to have no potential danger to fishes.

Development of tidal lagoon power is a distinct possibility in Minas Basin or at other sites in the inner Bay of Fundy (Cornett et al. 2013). There has already been one application with a proposal for Scots Bay just outside Minas Basin. The project would have involved a $10 \mathrm{~km}$ long barrage across Scots Bay containing 304 bulb turbines generating $1100 \mathrm{MW}$ (Towse 2014). Because the bulb turbines were small, they would have had a generation speed of 90 RPM and low water discharges. These characteristics of the turbines would create a short water length in the draft tube $(1.5 \mathrm{~m})$ resulting in high fish mortality during passage (Van Raben 1957). A similar 254 MW tidal power project was developed in Korea using the same bulb turbines that is considered very successful (Won 1980, Sandru 2011) but it has caused mortalities to fishes and marine mammals (Towse 2014).

\section{THE ENVIRONMENT}

Minas Basin $\left(45^{\circ} 19^{\prime} \mathrm{N}, 64^{\circ} 00^{\prime} \mathrm{W}\right)$ is a mega-tidal, cul-de sac marine embayment on the southeastern side of the inner Bay of Fundy and is semi-enclosed by the Province of Nova Scotia (Bousfield and Leim 1959). The triangular basin is $80 \mathrm{~km}$ long and $29 \mathrm{~km}$ wide at the base and $\sim 2000 \mathrm{~km}^{2}$ in area. It consists of the central Minas Basin proper, Cobequid Bay the eastern extremity inside Economy Point, and the Southern Bight (Fig 1). Maximum depth in the Basin is $17 \mathrm{~m}$ at low tide. Minas Basin has the largest recorded tides in the world (mean $11 \mathrm{~m}$, maximum $17 \mathrm{~m}$; Garrett 


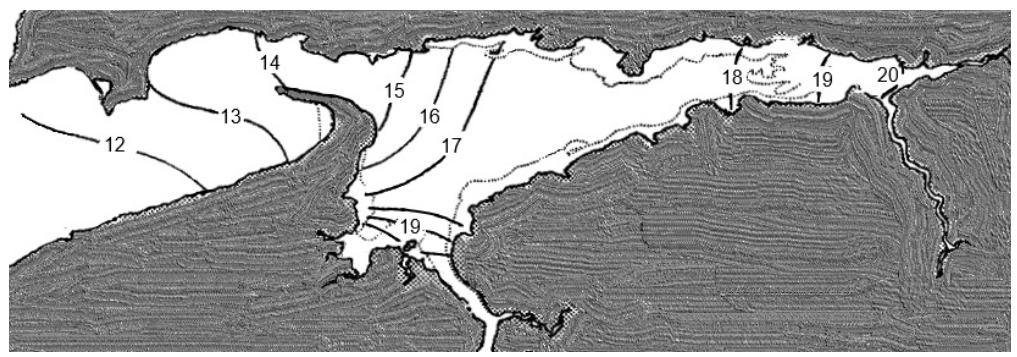

Fig 3 Isopleths of maximum summer, sea surface temperatures in Minas Basin, Minas Passage and Minas Channel, inner Bay of Fundy (after Bousfield and Leim 1959).

1972) and at low tide about one third of the Basin area $\left(670 \mathrm{~km}^{2}\right)$ is exposed as tide flat (Parker et al. 2007). The tidal regime is semidiurnal and an estimated $3 \times 10^{9} \mathrm{~m}^{3}$ of water flows in and out of the Basin with each tide (Parker et al. 2007). Owing to strong tidal forcing over shallow bathymetry, water exchange ratios vary from 0.39-0.60 a tidal cycle (Ketchum and Keen 1953). Because of the extreme tides the water column is homogeneous for temperature and salinity. Sea surface temperature (SST) ranges from a peak of 16-22 $\mathrm{C}^{\circ}$ in summer (Fig 3, August-September; Bousfield and Leim 1959, Wehrell 2005, Dadswell et al. 2020) to -1.5-0.0 $\mathrm{C}^{\circ}$ in winter (February, Bleakney and McAllister 1973). Winter is characterized by drifting ice pans up to $5 \mathrm{~m}$ thick which in some years cover most of the Basin from January to March and severely scour the substrate of the intertidal zone (Desplanque and Mossman 1998, Sanderson and Redden 2015). During some years ice blocks can be the size of a house (Fig 4).

Numerous rivers and streams are tributary to Minas Basin. The largest are the Salmon and Shubenacadie Rivers entering Cobequid Bay and the Avon, Gaspereau and Cornwallis entering the Southern Bight. Inflow of freshwater to Minas Basin from its catchment averages approximately $239 \mathrm{~m}^{3} \cdot \mathrm{s}^{-1}$ annually but during July through September decreases to about $99 \mathrm{~m}^{3} \cdot \mathrm{s}^{-1}$ (Bousfield and Leim 1959). Salinities range from 22 at the inner ends of Cobequid Bay and the Southern Bight to 30 in the central Basin (Fig 5, Bousfield and Leim 1959, Sanderson and Redden 2015).

Because of the extreme tides much of the subtidal, benthic substrate in Minas Basin is sand, gravel or rock (Amos 1984, McLean et al. 2013) with extensive intertidal zones (1-5 km wide) of sand, 


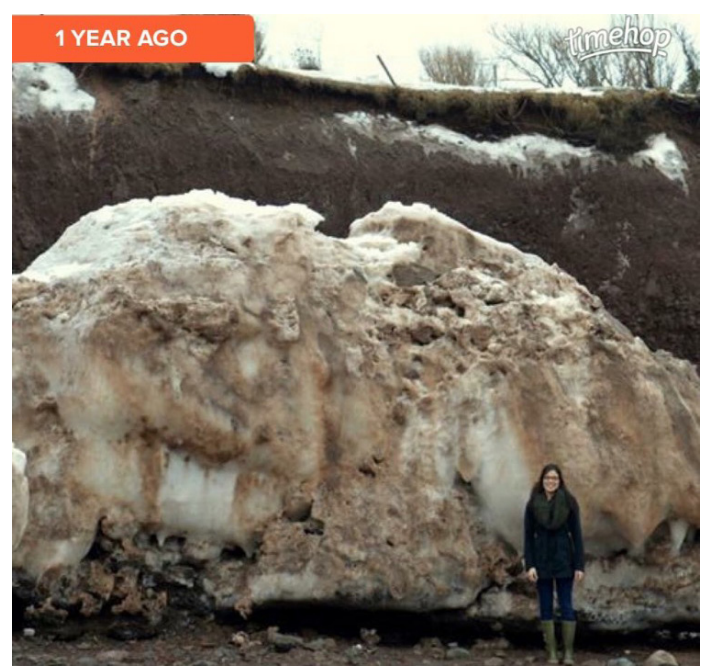

Fig 4 An ice block grounded on the upper intertidal zone near Bramber, Nova Scotia, March 2016. For scale the woman in front of the ice block is $\mathbf{1 . 5} \mathbf{~ m}$ in height (photograph courtesy D. Porter, Avondale, NS).

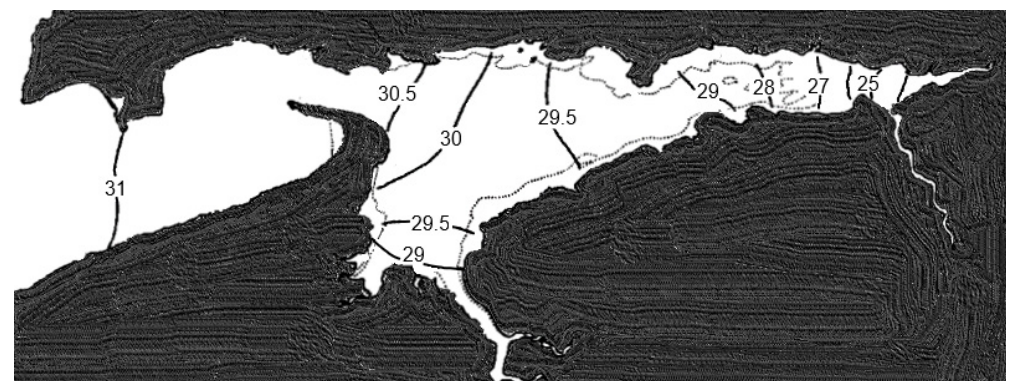

Fig 5 Surface salinity isopleths during summer in Minas Basin, Minas Passage and Minas Channel, inner Bay of Fundy (after Bousfield and Leim 1959).

silt and mud (Bleakney and McAllister 1973, Parker et al. 2007). Minas Basin has low to high turbidity depending on tidal amplitude, site and time of year (Amos 1984). Turbidity caused by the extreme tides is lowest during neap tides and in summer, highest during spring tides and in winter (Dadswell et al. 1983). Turbidity is highest in Cobequid Bay, the Southern Bight and the Avon estuary (Fig 6, Greenburg and Amos 1981). Suspended sediment and detrital levels in the macrotidal regions of the $\mathrm{iBoF}$ dramatically reduces light penetration. Detrital suspended particulate matter (SPM) can reach 


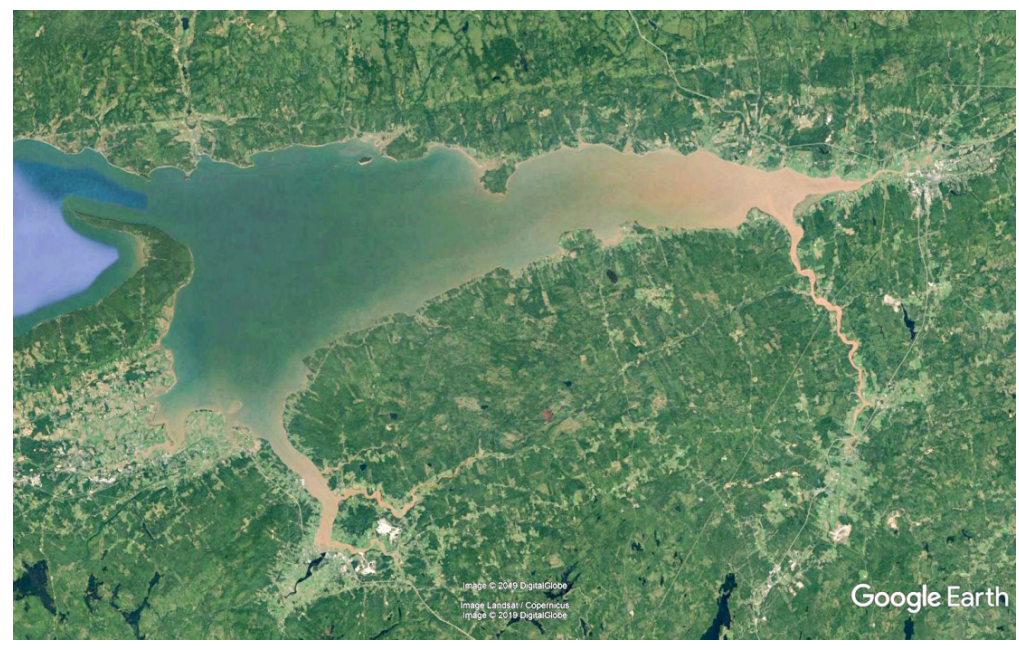

Fig 6 Turbidity in Minas Basin and Minas Passage, inner Bay of Fundy. High turbidity levels occur where the water is brown in Cobequid Bay, the Avon River estuary and the Southern Bight, www.googleearth.

$240 \mathrm{mg} . \mathrm{L}^{-1}$ (Crammen 1984) and secchi disk visibility decreases to $10-20 \mathrm{~cm}$ at tidal amplitudes over $8 \mathrm{~m}$ while light intensity declines to $<4.6 \times 10^{-3} \mu \mathrm{w} . \mathrm{cm}^{-2}$ at $3 \mathrm{~m}$ (Dadswell et al. 1983).

The movement of water in Minas Basin is driven by the residual element of tidal flow. This is the net flow created by the back and forth motion of tidal action and the bulk flow of water through the Basin. The residual flow results in a figure eight current pattern in the Basin (Fig 7, Greenberg 1984). Residual inflow enters along the north side of Minas Passage after being deflected northward by Cape Split. Flow continues along the north side of Minas Basin and then is deflected to the south side of Cobequid Bay by Economy Point. The residual current continues around Cobequid Bay on its north side and is again deflected to the south side of Minas Basin by Economy Point. A gyre exists in the central portion of Minas Basin and flow continues along the southern shore of the Basin through the Southern Bight exiting the Basin past Blomidon via the south side of Minas Passage.

Minas Passage is the body of water connecting the inner Bay of Fundy with Minas Basin (Fig 1). It is $15 \mathrm{~km}$ long and $\sim 5 \mathrm{~km}$ wide with low tide depths of 35-115 m. Minas Passage has SST's of $14-16^{\circ} \mathrm{C}$ from June to October (Fig 3, Bradford 1987) and because of powerful currents the water column is isothermal from bottom to surface (Tee 1975, AECOM 2009). Because of the extensive 


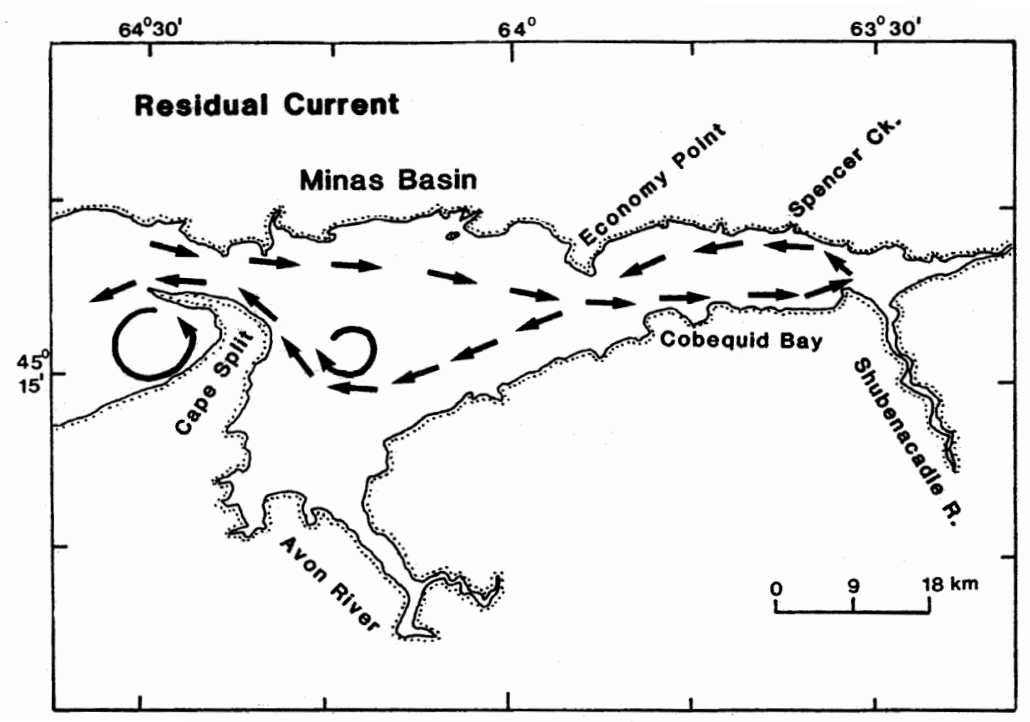

Fig 7 Residual currents in Minas Basin (adapted from Greenberg 1984).

upwelling caused by the currents Minas Passage is warmer in winter than Minas Basin. Winter temperatures range from $6.0^{\circ} \mathrm{C}$ in December to $1.0^{\circ} \mathrm{C}$ in March (Keyser et al. 2016). Salinity in the Passage ranges from 30-32 (Bousfield and Leim 1959, Sanderson and Redden 2015). Minas Passage also has clearer water compared to Minas Basin (Fig 6) seldom experiencing turbidity except during spring tides in winter.

Minas Passage is a region of complex and powerful currents caused by the extreme tides and shape of the shoreline. Approximately 14 billion metric tons $(t)$ of water flow into and out of the Passage during each phase of the tide cycle, a volume greater than all the rivers on earth (Karsten et al. 2013). Tidal velocities from 3-6 m.s. $\mathrm{s}^{-1}$ occur in Minas Passage during falling and rising tides and large gyres have been identified around Cape Split and Cape Blomidon (Fig 7, 8, Tee 1975, Greenberg 1984). Residual currents were calculated with speeds up to $0.75 \mathrm{~m} . \mathrm{s}^{-1}$ (Tee 1975). The strong tidal velocities have scoured most of the substrate of Minas Passage to bedrock (AECOM 2009).

Currents through Minas Passage are strongly influenced by Cape Split (Fig 8). During flood tide flow is deflected northward by the Cape and the strongest currents $\left(5-6 \mathrm{~m} \cdot \mathrm{s}^{-1}\right)$ occur along the north 


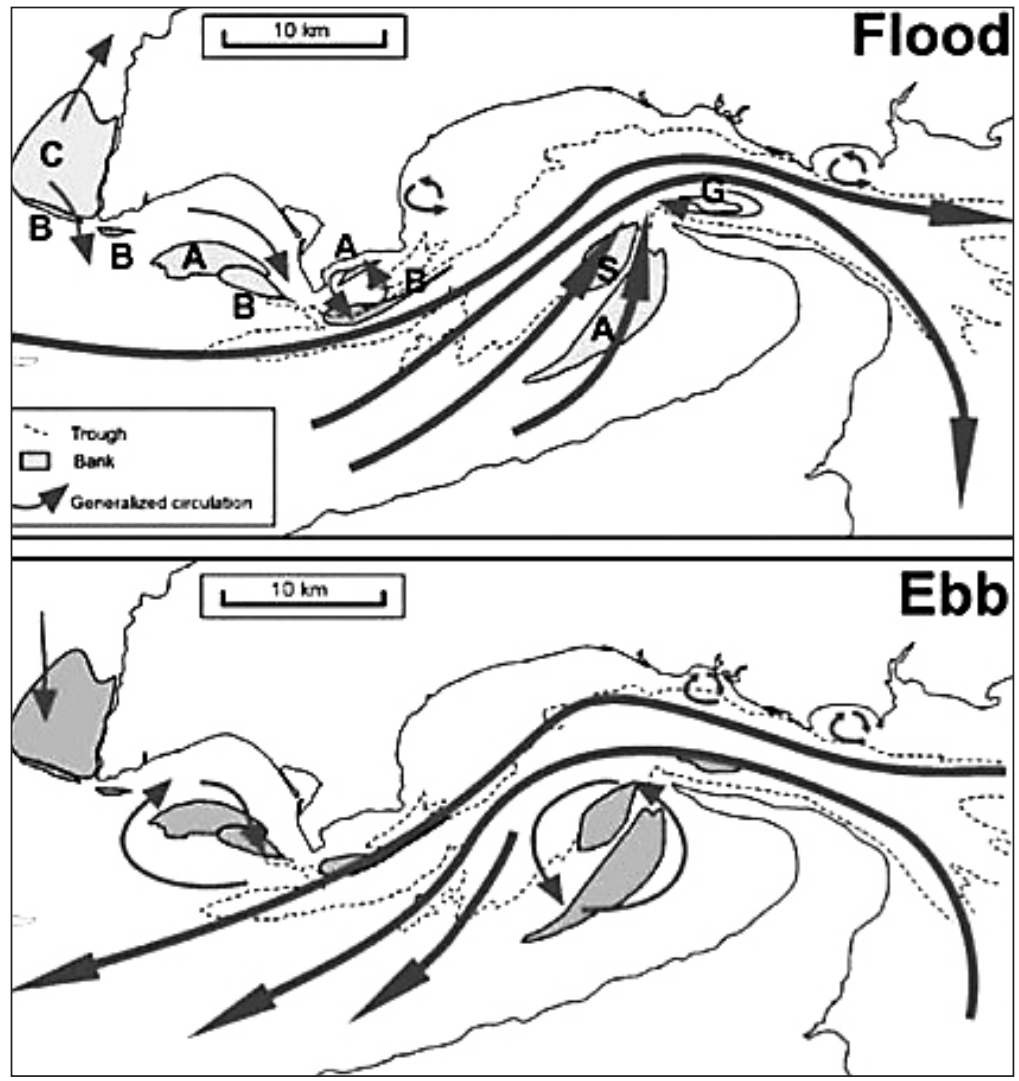

Fig 8 Flood tide and ebb tide flow directions in Minas Channel and Minas Passage. Arrows indicate generalized direction of flow. Dotted line indicates the $30 \mathrm{~m}$ high tide depth contour (adapted from Towse 2014).

shore of the Passage (AECOM 2009, Walters et al. 2013). During ebb tide currents across the Passage are similar ( $3 \mathrm{~m} . \mathrm{s}^{-1}$, Tee 1975, Walters et al. 2013) but the outflow past Cape Split creates a large gyre on the north side of Scot's Bay (Fig 8, G. Travis, commercial fisher, pers. comm.).

\section{MIGRATION OF FISHES IN THE BAY OF FUNDY AND MINAS BASIN}

Numerous studies on the fishes of the Bay of Fundy indicate most species migrate through the Bay of Fundy following the tidal, residual flow pattern. Residual flow in the Bay describes 
counterclockwise pattern entering the Bay on the south-east along the coast of Nova Scotia and exiting on the north-west side of the Bay along the New Brunswick shore (Fig 9, Lauzier 1967). The annual migration pattern of large sharks (Dadswell et al. 1984a), Atlantic sturgeon (Dadswell et al. 2016), Atlantic salmon (Saunders 1969, Meister 1984), coho salmon (Martin and Dadswell 1983), American shad (Dadswell et al. 1987), Atlantic herring (McKenzie and Tibbo 1961), haddock (McCracken 1965) and winter flounder (McCracken 1963) all display the same overall counterclockwise migratory pathway around the Bay of Fundy.

The American shad migratory pattern is well known and demonstrates how these fish closely follow the residual currents both in the Bay of Fundy and Minas Basin (Fig 10, Dadswell et al. 1987). American shad enter the Bay each year during April-May along the Nova Scotia shore, arrive in Minas Basin during June-July and exit along the New Brunswick shore in September-October. Migratory speeds are about $3.5 \mathrm{~km} . \mathrm{d}^{-1}$ (Dadswell et al. 1987) which is slightly faster than the speed of the residual current $\left(3.0 \mathrm{~km} . \mathrm{d}^{-1}\right.$, Lauzier 1967). Inside Minas Basin shad follow the residual current closely, their migration taking a figure eight pattern like the current (Fig 10, Dadswell et al. 1984b).

Currents and gyres would be expected to hinder the progress of smaller species and life stages through Minas Passage because of the

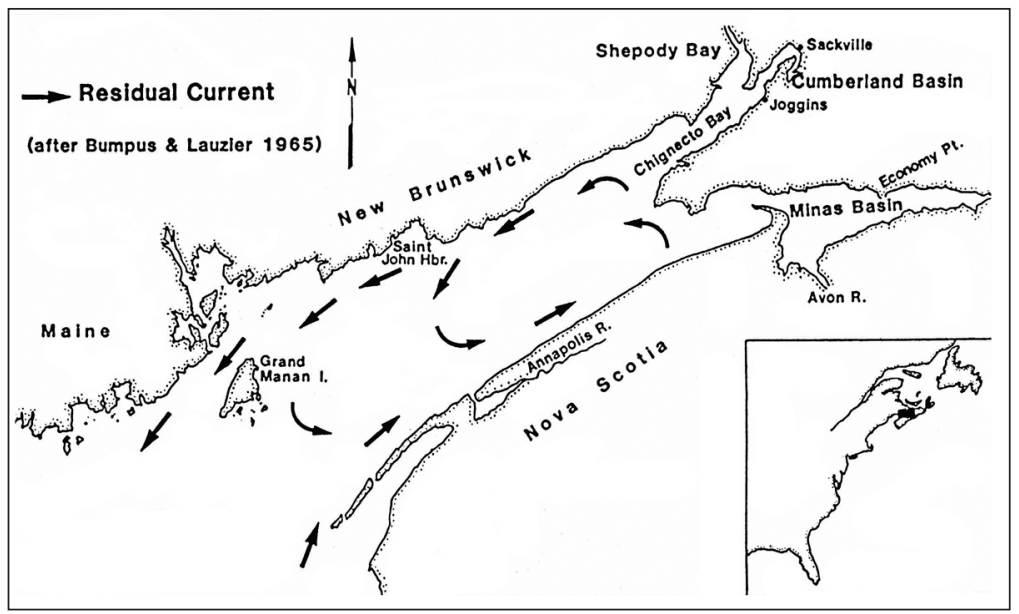

Fig 9 Residual currents in the Bay of Fundy (adapted from Lauzier 1967). 


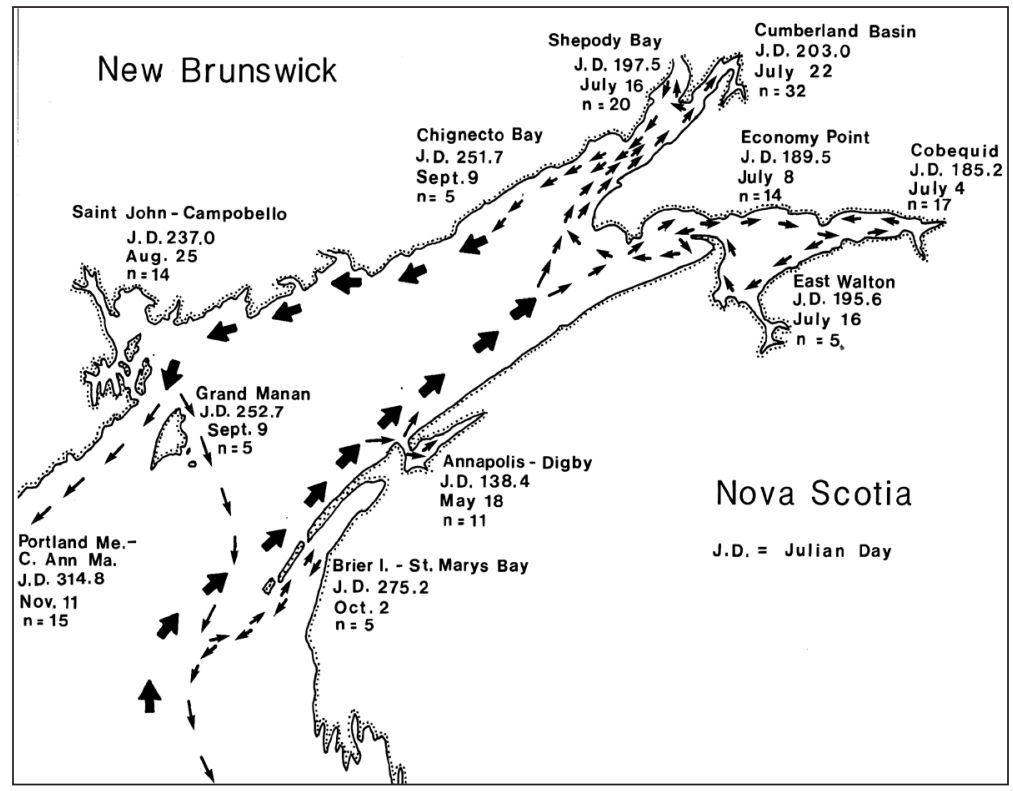

Fig 10 Migration pathway, seasonal time (mean date, Julien day) and number of tag returns of American shad from each locality in the Bay of Fundy during 1979-1985.

extreme tidal and residual velocities (Tee 1975, Walters et al. 2013) but may help to speed the progress of larger species and life stages. In general, fishes make about 2 body lengths/s $\left(\mathrm{bl} . \mathrm{s}^{-1}\right)$ at cruising speed (Moyle and Cech 1996) and fishes smaller than about $20 \mathrm{~cm}$ in length, like Atlantic salmon smolts, can be held up in Minas Passage for longer periods than their average migration rates especially if caught up in the gyres (Lacroix et al. 2005).

Most large species entering Minas Basin apparently hold in the large gyre in Scots Bay during ebb tide and move into Minas Basin on the flood tide (Fig 8, G. Travis, commercial fisher, pers. obs.). This behavior can lead to extremely large bottom trawl catches at this site (Fig 11). Additionally, fishes follow the main current flow into and out of Minas Passage. American shad and Atlantic sturgeon enter Minas Basin predominately along the northern shore (Dadswell et al. 1987, Dadswell et al. 2016). Atlantic sturgeon departing Minas Basin during autumn predominately move along the southern shore of Minas Passage (Stokesbury et al. 2016). 


\section{THE FISHERIES OF MINAS BASIN AND MINAS PASSAGE}

The fisheries of the inner Bay of Fundy began with the native Mi'kmaq. They used intertidal weirs and spears to capture fish for sustenance and trade (Gordon 1993). They captured Atlantic sturgeon, Atlantic herring, gaspereau, American shad, Atlantic salmon, Atlantic cod, tomcod and smelt.

When European settlers arrived during the 1600's the Mi'kmaq taught them how to use weirs to catch fish for their survival. Intertidal weirs are constructed during spring of spruce stakes with interwoven brush or netting in a V-shape with the $\mathrm{V}$ pointed offshore (Fig 12, Gordon 1993). At high tide the weir is underwater. As the tide ebbs fishes are guided into the weir pond that is then fished at low water. Before 1900 catches of 100,000 shad a tide occurred (Perley 1852, Prince 1912). Horse-drawn wagons were used to land the catch. Some weirs in Minas Basin were serviced with horses until the 1980's (Dadswell et al. 1984a) but are fished now with trucks or all-terrain vehicles (Fig 12).

Intertidal fish weirs have remained one of the main methods for fisheries in Minas Basin to the present day. During the 1800's hundreds of fish weirs lined the shores of Minas Basin and the American shad captured were so important to the economy of Nova Scotia that a Special Act of the Nova Scotia Legislature was passed in 1840 for its regulation, one of the first in Canada (Perley 1852). Today the main catch is gaspereau or river herring a mixture of the two species Alosa pseudoharengus and A. aestivalis that are very difficult to tell apart and which are used mainly as bait for the lobster fishery (Baker et al. 2014, Dadswell et al. 2020). Other commercial species captured now or in the past are Atlantic sturgeon, Atlantic salmon, Atlantic herring, American shad, striped bass, butterfish, winter flounder, tomcod, American smelt and Atlantic mackerel.

A drift, gill net fishery began in Minas Basin during the 1800's and has continued until the present (Huntsman 1958, Dadswell et al. 1984b). Species targeted were Atlantic salmon, gaspereau and American shad. Linen nets were used until the 1970's when the nets were changed to multifilament nylon. Nets were usually $6 \mathrm{~m}$ deep and $30 \mathrm{~m}$ long and were fished in gangs up to $1.5 \mathrm{~km}$ in length (Dadswell et al. 1984b). Cape Island vessels of 10-15 $\mathrm{m}$ in length were most often used (Fig 13). The fishery for Atlantic salmon 


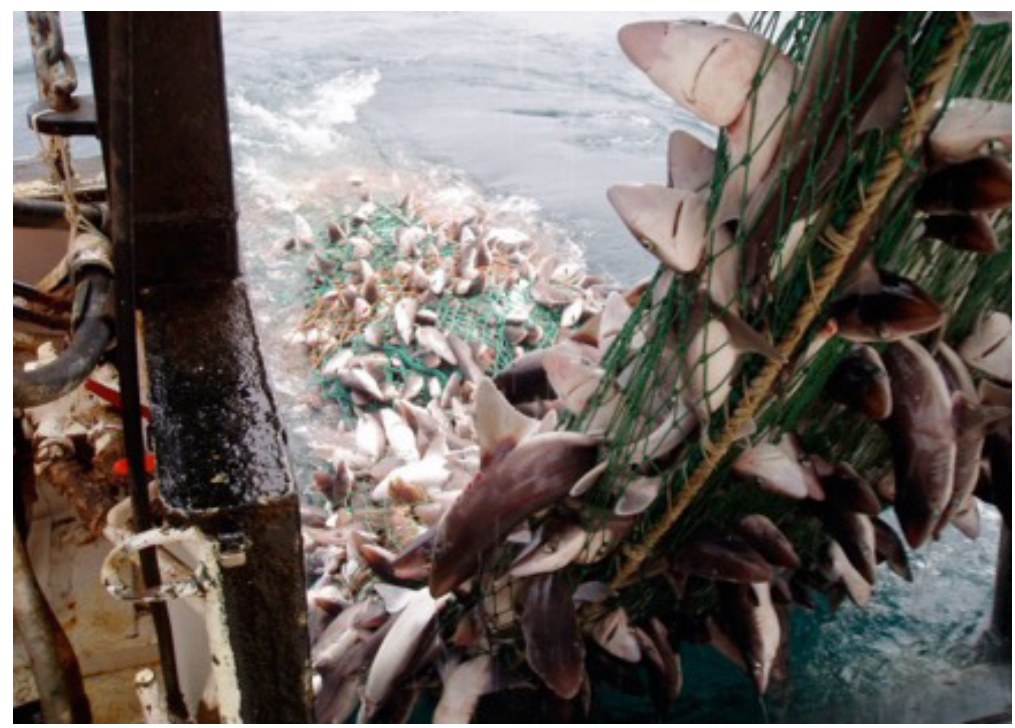

Fig 11 Spiny dogfish shark captured during a one-half hour tow with a 'RockHopper' trawl in Scots Bay off the western side of Cape Split, July 2004 (photograph courtesy S. Wehrell, Acadia University).

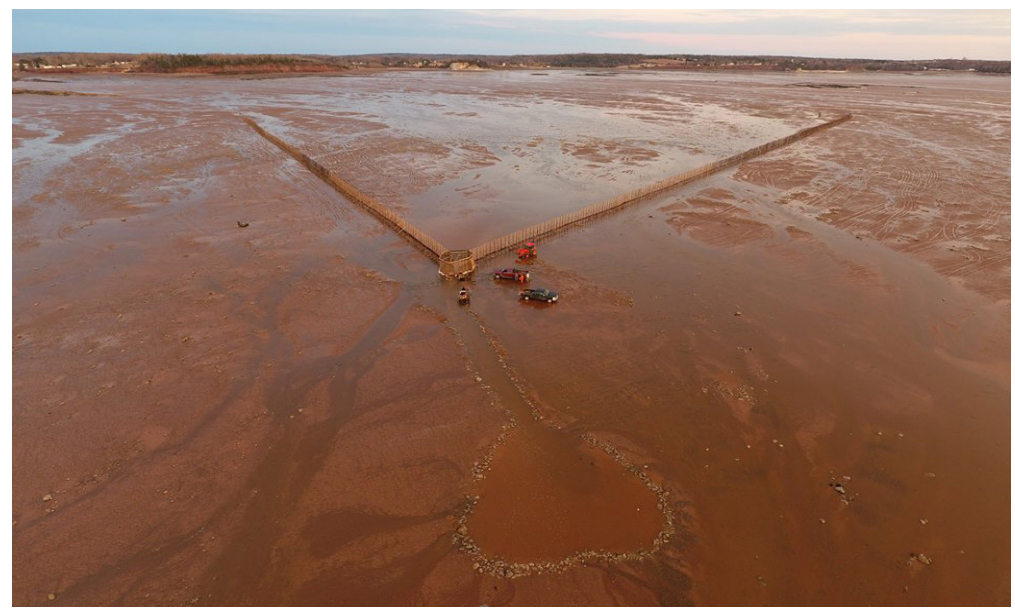

Fig 12 The Bramber weir at low tide in Minas Basin that was used for the 2017 weir study (Dadswell et al. 2020). The v-shaped wings direct fish into the trap at the bottom of the photograph. Fisher's trucks are clustered around the trap. The channel leading from the trap and heart shaped structure (pond) is where fishes prohibited from take (sturgeon, striped bass, salmon) are released alive to await the return of the tide (photograph courtesy D. Porter, Avondale, NS). 


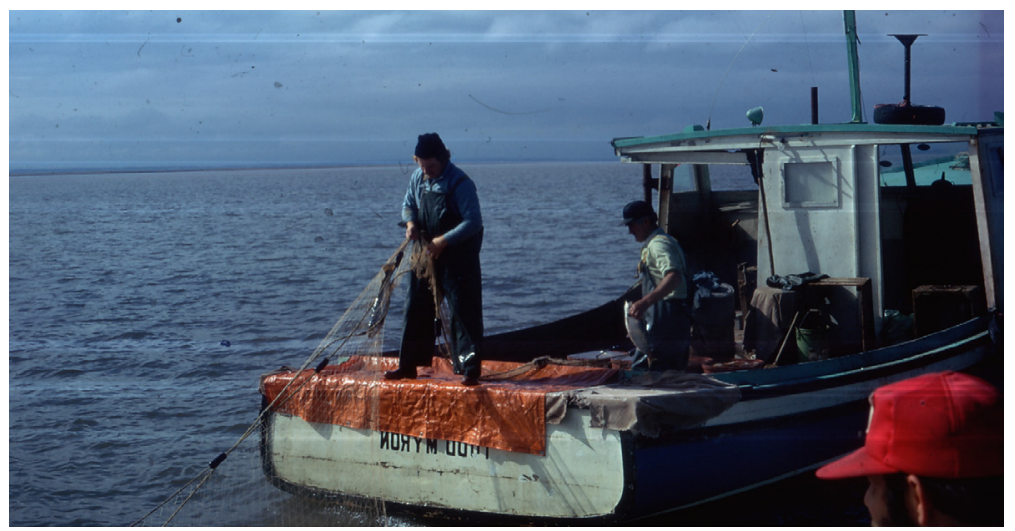

Fig 13 Cape Islander fishing vessel of the type used in the drift gill net fishery in the inner Bay of Fundy. The fisher hauling the net has an Atlantic salmon close to his hand; the deck hand has an American shad in his hand. The picture was taken during 1982 when the salmon fishery was still permitted (photograph MJD).

was closed in 1984 but drift netting for gaspereau and American shad remains active. There used to be a large, hand line and drift net fishery for pollock in Minas Passage (Perley 1852). Pollock are still taken there commercially and recreationally but since the pollock stock collapsed after 1970 only hand lines are used (Dyer et al. 2005).

A trawler fishery began in Minas Basin during the 1950's and is still pursued annually. The season is from June 1 to October 31 (Wehrell 2005). The main species targeted are winter flounder and dogfish shark with a bycatch of cod and striped bass. Fishers use a $24 \mathrm{~m}$ wide, Yankee 33, box trawl with $14.0 \mathrm{~cm}$ stretched mesh in the trawl body and cod end and towed with $200 \mathrm{~kg}$ Bison doors (Wehrell 2005). A set usually lasts from 1-2 hours in length. There are 4-5 trawlers that work out of Delhaven and Parrsboro using vessels $<14 \mathrm{~m}$. All-bay, $>18 \mathrm{~m}$ vessels from Yarmouth and Metegan also fish Minas Basin using similar trawls.

There is a small fishery for spring herring in the intertidal zone using $3.6 \mathrm{~cm}$ stretched mesh fixed gill nets. Fishers are restricted to $30 \mathrm{~m}$ of net.

Since 1990 a large angling fishery for striped bass has developed in Minas Basin (Broome et al. 2009). Fishers are allowed only one bass a day with a minimum total length of $68.5 \mathrm{~cm}$. Anglers also fish for flounders and dogfish shark. 


\section{COMPILATION OF THE FISHES}

Details are provided on a total of 85 fish species that have either been recorded in Minas Basin, Minas Passage and/or Minas Channel or can reasonably be expected to occur in the region. Systematic and taxonomic names (www.fishbase.org) are provided as a narrative for easy access to species information and scientific references. Where information is available seasonal migratory timing, water column distribution, known or expected abundance and past and present fisheries are provided. Maximum length is either fork $\left(\mathrm{L}_{\mathrm{F}}\right)$ or total $\left(\mathrm{L}_{\mathrm{T}}\right)$ length. It is very likely that more fish species occur in Minas Passage than are listed and their abundance could be greater than anticipated. These details will be determined as fish studies in the Passage progress.

The fishes are also categorized with regard to their potential risk of interaction with tidal lagoons (Cornett et al. 2013) or proposed instream, axial-flow, hydraulic lift propeller turbines, the only type of hydrokinetic device that has been deployed on Minas Passage to date (AECOM 2009, FORCE 2017). The extreme impact category includes fishes that have a high probability of interaction with a propeller turbine and/or potential for significant harm to their population. The medium category contains fishes with some probability of interaction and a moderate risk of harm, and the low category, fishes with a low probability of interaction or harm. Degree of potential harm (Table 1) is determined by fish size and susceptibility to propeller turbine passage impact (strike, pressure effects, shear and cavitation; Dadswell and Rulifson 1994), their habitat (pelagic or benthic), their importance to fisheries and the size of their population (abundant, rare, endangered). A total of 13 fishes are suggested for the extreme category, 10 in the medium category and 62 in the low category.

A number of fishes which are known to occur in either Minas Basin or Minas Passage have been assessed as at-risk by the Committee on Endangered Wildlife in Canada (COSEWIC) and/or are listed under the Canadian Species at Risk Act (SARA). Inner Bay of Fundy Atlantic salmon (SARA, endangered, Schedule 1), great white shark (SARA, endangered, Schedule 1), shortnose sturgeon (SARA, special concern, Schedule 1) Atlantic wolffish (SARA, special concern, Schedule 1) are protected to one degree or another and require 
Table 1 Summary of important Minas Basin/Passage fishes and their level of potential impact from propeller tidal turbines deployed in Minas Passage. The extreme category contains fishes that are likely to have population level impacts. The moderate category could expect some instances of high mortality and fisheries declines but unlikely with overall population effects.

\begin{tabular}{lccccc}
\hline Species & Lmax $^{\mathbf{a}}$ & Habitat $^{\mathbf{b}}$ & Population Size & Status $^{\mathbf{c}}$ & Fishery Impact $^{\mathbf{d}}$ \\
EXTREME RISK & & & & & \\
\hline Basking shark & 10.0 & $\mathrm{P}$ & $1-10$ & $\mathrm{SC}$ & $\mathrm{na}$ \\
Great white shark & 5.0 & $\mathrm{P}$ & $10-20$ & $\mathrm{E}$ & $\mathrm{na}$ \\
Porbeagle & 3.0 & $\mathrm{P}$ & 100 & $\mathrm{nl}$ & $\mathrm{na}$ \\
Dogfish shark & 1.1 & $\mathrm{~B}-\mathrm{P}$ & $2000 \mathrm{~K}+$ & $\mathrm{SC}$ & $\mathrm{na}$ \\
Atlantic sturgeon & 3.0 & $\mathrm{~B}-\mathrm{P} *$ & $10 \mathrm{~K}$ & $\mathrm{~T}$ & $\mathrm{H}$ \\
Atlantic salmon & 1.0 & $\mathrm{P}$ & $1000 ?$ & $\mathrm{E}$ & $\mathrm{H}$ \\
American shad & 0.6 & $\mathrm{P}$ & $3000 \mathrm{~K}+$ & $\mathrm{nl}$ & $\mathrm{H}$ \\
Atlantic herring & 0.5 & $\mathrm{P}$ & $10000 \mathrm{~K}+$ & $\mathrm{nl}$ & $\mathrm{H}$ \\
Blueback herring & 0.5 & $\mathrm{P}$ & $5000 \mathrm{~K}+$ & $\mathrm{nl}$ & $\mathrm{M}$ \\
Alewife & 0.5 & $\mathrm{P}$ & $5000 \mathrm{~K}+$ & $\mathrm{nl}$ & $\mathrm{M}$ \\
Striped bass & 1.5 & $\mathrm{P}$ & $100 \mathrm{~K}$ & $\mathrm{~T}$ & $\mathrm{H}$ \\
Pollack & 1.0 & $\mathrm{P}$ & $?$ & $\mathrm{nl}$ & $\mathrm{M}$ \\
Atlantic halibut & 3.0 & $\mathrm{~B}-\mathrm{P}$ & $100 ?$ & $\mathrm{nl}$ & $\mathrm{H}$ \\
& & & & & \\
\hline
\end{tabular}

\section{MODERATE RISK}

\begin{tabular}{lccccc}
\hline Sea lamprey & 0.8 & $\mathrm{P}$ & $10 \mathrm{~K}$ & $\mathrm{nl}$ & $\mathrm{na}$ \\
Sand tiger shark & 3.3 & $\mathrm{~B}$ & 10 & $\mathrm{nl}$ & $\mathrm{na}$ \\
Shortnose sturgeon & 1.4 & $\mathrm{~B}$ & 10 & $\mathrm{SC}$ & $\mathrm{na}$ \\
American eel & 1.0 & $\mathrm{P}$ & $100 \mathrm{~K}+$ & $\mathrm{T}$ & $\mathrm{M}$ \\
Rainbow smelt & 0.3 & $\mathrm{P}$ & $50000 \mathrm{~K}+$ & $\mathrm{nl}$ & $\mathrm{L}$ \\
Atlantic cod & 1.5 & $\mathrm{~B}-\mathrm{P}$ & 1000 & $\mathrm{E}$ & $\mathrm{L}$ \\
Mackerel & 0.6 & $\mathrm{P}$ & $100 \mathrm{~K}+$ & $\mathrm{nl}$ & $\mathrm{L}$ \\
Lumpfish & 0.8 & $\mathrm{P}-\mathrm{B}$ & $?$ & $\mathrm{~T}$ & $\mathrm{na}$ \\
Wolffish & 1.5 & $\mathrm{~B}$ & $?$ & $\mathrm{SC}$ & $\mathrm{L}$ \\
Winter Flounder & 0.6 & $\mathrm{~B}$ & $100 \mathrm{~K}+$ & $\mathrm{nl}$ & $\mathrm{L}$ \\
\hline
\end{tabular}

${ }^{a}$ Lmax Maximum length in meters

bPelagic (P), Pelagic-Benthic (P-B) or Benthic (B).

'Listed by COSEWIC or SARA as endangered (E), threatened (T), special concern (SC) or not listed (nl)

${ }^{\mathrm{d}}$ High (H), Moderate (M), Low (L) or not applicable since no fishery (na)

${ }^{\mathrm{e}} \mathrm{K}=1,000$.

*Atlantic sturgeon traverse Minas Passage pelagically (Stokesbury et al. 2016).

an 'assessment of harm' for any potential environmental impact. COSEWIC has assessed Shortfin mako, porbeagle and Atlantic cod as 'endangered', Atlantic sturgeon, American eel, lumpfish, striped bass and white hake as 'threatened' and spiny dogfish, thorny and smooth skate and basking shark as 'special concern'. 


\section{SUPERCLASS: AGNATHA 'JAWLESS FISHES'}

\section{Order: Myxiniformes 'hagfish'}

1. Atlantic hagfish Myxine glutinosa Linnaeus, 1758. Marine, benthic. Hagfish are abundant in the outer Bay of Fundy over mud bottoms (Scott and Scott 1988). They are benthic scavengers that usually burrow into the substrate during daytime. They are mostly associated with deep, cold water habitats and are especially abundant in the deep ocean around 'whale falls' (Moyle and Cech 1996).

Hagfish attack dead and dying fishes and will feed on shrimp. Sampling with baited traps can capture up to 500 hagfish during a 12 h set in Passamaquoddy Bay (Scott and Scott 1988). Hagfish have never been observed in the inner Bay of Fundy but possibly occur in Minas Basin and Passage especially during winter where there are subtidal mud substrates. They would accumulate around turbines if there were dead fish to feed on. Their risk for turbine interaction is low.

There is a world-wide fishery for hagfish. Hagfish skin is made into 'fish leather' and Koreans appreciate them as food (Knapp et al. 2011). There is a hagfish fishery in the Bay of Fundy (Ellis et al. 2015).

\section{Order: Petromyzontiformes 'lampreys'}

2. Sea lamprey Petromyzon marinus Linnaeus, 1758. Anadromous, benthic, pelagic. Larval lampreys or 'ammocetes' are benthic in fresh water where they burrow into mud and silt of stream shorelines. Juveniles and adults are pelagic in marine situations and are blood predators of fishes (Halliday 1991).

Sea lampreys are semelparous and spawn in freshwater streams during April-July after which the adults die. After hatching ammocetes remain burrowed into sand-silt bottoms of streams for up to seven years before they metamorphose into juveniles during spring and then migrate to sea (Scott and Scott 1988).

Juvenile and adult lampreys attach to their prey with an anterior sucker equipped with multiple teeth used to bore through the skin and into the muscle (Scott and Scott 1988). They then inject an anticoagulant and pump out the fish blood. Their feeding often kills their prey. They begin preying on fishes for blood as juveniles during estuarine emigration. Maritime populations migrate to sea and live offshore on the Scotian Shelf or further seaward for an indeterminate 
period (Scott and Scott 1988, Halliday 1991). Lampreys are difficult to capture when in mid-water, marine situations because of their eel like form which allows them to escape from most sampling gear (Halliday 1991). Juveniles and adults prefer to feed on soft bodied fishes such as salmon and shad.

Lamprey are known from the Shubenacadie, Gaspereau and Kennetcook Rivers in Minas Basin (Leim and Scott 1966), but probably also occur in all other Minas Basin streams with anadromous fish populations. Ammocetes are common in shallow, silt covered sites along stream shorelines. Juveniles migrating offshore are abundant in Minas Basin during spring (April-June) attached to adult and juvenile gaspereau, shad and salmon. Adults migrating inshore to spawn are found in the pelagic zone of Minas Basin and Passage during April-June. Adults do not feed when migrating to spawn. Adult abundance during inward migration through Minas Passage would probably be in the range of 1000-10,000 $\mathrm{y}^{-1}$.

There is no fishery for lampreys in Canada. In Europe they are captured in weirs and pickled. King John of Robin Hood fame died after overindulging on pickled lampreys, his favorite food.

Adult sea lampreys will be susceptible to turbine strike because of their body size, pelagic habitat and attachment to other fishes. Adults may be up to $80 \mathrm{~cm} \mathrm{~L}$. They have been judged to be at low risk during interaction with axial-flow turbines (Gibson and Myers 2002).

\section{SUPERCLASS: CHONDRICHTHYES 'CARTILAGINOUS FISHES' CLASS: ELASMOBRANCHII 'SHARKS'}

Many of the sharks have large body size (1-10 $\left.\mathrm{m} \mathrm{L}_{\mathrm{T}}\right)$ which increases their chance of blade strike during propeller turbine passage. Also, sharks are mostly predators and scavengers (Moyle and Cech 1996) and although most are never common or abundant in Minas Basin or Passage there is a good probability they will be attracted to the Minas Passage turbine sites if there are dead or wounded fish present. Such behavior will further increase their chances of propeller turbine impact.

\section{Order: Carchariniformes}

3. Sand tiger shark Carcharius taurus Rafinesque, 1810. Marine, benthic. Sand tiger, a southern species is a rare shark in Canada. 
Two specimens have been observed in the outer Bay of Fundy (Scott and Scott 1988). Two were captured by drift gill net in Minas Basin during August 1985 (Dadswell and Rulifson 1994) and one, $\sim 2 \mathrm{~m}$ on length, was taken in a weir at Economy in Minas Basin during August 2017 (Fig 1, W. Linkletter, pers. comm.). Sand tiger may be more common in Minas Basin than observations suggest since the sandy bottom habitat they prefer is widely available in the Basin and summer water temperatures often exceed $20 \mathrm{C}^{\circ}$ (Bousfield and Leim 1959, Wehrell 2005).

Records indicate this species would be occasional in Minas Basin and Passage and would only be encountered incidentally during summer. Abundance expected would probably be in the range of $1-10 \mathrm{y}^{-1}$.

Since body length of sand tigers can be up to $3.3 \mathrm{~m} \mathrm{~L}_{\mathrm{F}}$ they are at moderate risk in axial-flow, hydraulic lift propeller turbines. Specimens captured in Minas Basin to date were 0.79-2.0 $\mathrm{m} \mathrm{L}_{\mathrm{F}}$.

\section{Order: Lamniformes}

4. Thresher shark Alopias vulpinus (Bonneterre, 1788). Marine, pelagic. There are three records of thresher shark captured in the Bay of Fundy (Scott and Scott 1988) and it may occur in the inner Bay. Specimens captured in the outer Bay of Fundy were large (3-5 $\mathrm{m} \mathrm{L}_{\mathrm{T}}$, Scott and Scott 1988) and large individuals have been taken off Yarmouth in shark derbies during recent years (Dadswell, pers. obs.). Large sharks that were tagged have been documented to travel long distances rapidly (up to $5000 \mathrm{~km}$, Casey and Kohler 1990) and virtually any species of large shark could be expected in the inner Bay of Fundy during summer.

Threshers feed on herring, alsoids and squid, all of which are abundant forage items in Minas Basin during summer (Dadswell et al. 1984a, Bradford and Iles 1992, Dadswell et al. 2020). Threshers could be expected in Minas during June to September but only in small numbers $\left(1-10 \mathrm{y}^{-1}\right)$. They would be attracted to turbine sites because of blood and vibrations created by wounded fishes. They would be in extreme danger of mechanical strike in axial-flow propeller turbines because of their large size. There is no fishery in the Bay of Fundy.

5. Great white shark Carcharodon carcharias (Linnaeus, 1758). Marine, pelagic. Piers (1934), Templeman (1963) and Scott and Scott (1988) have documented nine white sharks from the outer 
Bay of Fundy which were caught from July to November. Case (1968) documented a $5.2 \mathrm{~m} \mathrm{~L}_{\mathrm{T}}$ specimen caught in a drift gill net off Burntcoat Head in Minas Basin on August 15, 1966. A photograph of this specimen is in his publication. In August 2011, a juvenile great white $\left(3.0 \mathrm{~m} \mathrm{~L}_{\mathrm{T}}\right)$ was captured in a weir at Economy across the Basin from Burntcoat Head (W. Linkletter, pers. comm.). During 2013 three great whites tagged with acoustic tags off Massachusetts were detected in the OTN acoustic receiver line in Minas Passage (M. Stokesbury, pers, comm.). A dead, $3.0 \mathrm{~m}$ male great white beached in West Bay in Minas Passage during July 2015 (W. Joyce, DFO, pers. comm., Rees 2016) and during June-August 2017, a $2.7 \mathrm{~m} \mathrm{~L}_{\mathrm{T}}$ female great white, tagged acoustically off Massachusetts, was detected by receivers in the Southern Bight (D. Porter, pers. comm.). Similarly, on July 22, 2018 a great white took a striped bass off an angler's hook near Economy (CTV News July 23, 2018) and the great white that was in the Basin during 2017 was again acoustically detected in the Southern Bight during 2018 (D. Porter, commercial fisher, pers. comm.). Great white shark now appear to be common in Minas Basin during summer!

Large great white sharks captured in the Bay of Fundy had fed on harbour porpoise and harbour seals (Scott and Scott 1988). Great white stomachs are often filled with whale blubber thought to be from dead whales, but they are also known to attack living whales in packs (Carey et al. 1982). Since porpoise, seals and whales are abundant in all parts of the Bay of Fundy during the entire year (Gaskin et al. 1985, Tollit et al. 2011) great whites should be expected in Minas Basin and Passage especially during JuneAugust. Abundance may be low, probably not more than 5-10 $\mathrm{y}^{-1}$. There is no fishery for great white shark in Canada and they are listed by SARA as endangered. Because of their large size great white sharks are at extreme risk for blade strike in propeller tidal turbines. Their endangered status dictates there should be 'no take'.

6. Basking shark Cetorhinus maximus (Gunnerus, 1765). Marine, pelagic. Basking sharks are common in the Bay of Fundy during summer. Perley (1852), Templeman (1963) and Scott and Scott (1988) report 12 documented occurrences from the outer Bay. Specimens often wash ashore off Saint John Harbour on either side of the Bay after being struck by ships. One, living, basking shark was observed by a wind surfer inside Minas Basin off Evangeline Beach dur- 
ing September 1987 and a dead specimen was found off Alma in Chignecto Bay during early October 2008 (Dadswell, pers. comm.).

Basking sharks are one of the largest fishes in the ocean and attain lengths of over $10 \mathrm{~m} \mathrm{~L}_{\mathrm{T}}$ (Scott and Scott 1988). They filter feed on planktonic organisms, especially shrimp and they are known to dive to depths of $300 \mathrm{~m}$ at night to feed (Tobey 1977). These sharks then rise to the surface during daylight to 'bask' on the surface where they are struck and often killed by ships. They should be expected at depth or at the surface in Minas Passage during July to October. They will probably occur annually in Minas Basin and the Passage but numbers will be low $\left(1-10 y^{-1}\right)$. They are at extreme risk from propeller turbine strike (Table 1).

7. Shortfin mako shark Isurus oxyrinchus Rafinesque, 1810. Marine, pelagic. Apparently common in the outer Bay of Fundy during summer but has never been reported in the inner Bay (Scott and Scott 1988). Numerous specimens have been captured recently during shark fishing derbies and landed in Yarmouth (Dadswell, pers. obs.). Mature specimens are 2-3 $\mathrm{m} \mathrm{L}_{\mathrm{T}}$ in length. May occur rarely in Minas Passage and would be at extreme risk for propeller turbine strike.

8. Porbeagle Lamna nasus (Bonneterre, 1788). Marine, pelagic. Porbeagle is the most common shark species in the inner and outer Bay of Fundy other than dogfish shark. Until recently there was a commercial fishery for porbeagle in the inner Bay during summer (Anon 1986). Catches averaged about $10 t \mathrm{y}^{-1}$ (Campana et al. 2002). Recently, however, the porbeagle fishery was closed because of declining stock size (CSAS 2005, Campana 2007).

Porbeagle sharks are common in Chignecto Bay and Minas Basin during summer. Dadswell et al. (1984a) reported two captured at night with drift gill nets off Grindstone Point in Chignecto Bay on August 5 and September 3, 1980 (Fig 14). One was captured at night with drift gill nets in Minas Passage off Blomidon during July 1984 (Dadswell, pers. obs.). These three specimens were all females from 2.1-2.2 $\mathrm{m} \mathrm{L}_{\mathrm{T}}$. Another $318 \mathrm{~kg}$ female was captured in a herring net off Halls Harbour in Minas Channel on July 15, 1986 (Anon 1986).

Porbeagle is a fast swimming, epipelagic shark that feeds on salmon, herring, eels, alosids and squid (Scott and Scott 1988, Joyce et al. 2002). Porbeagles probably follow the abundant herring and alosid runs that occur in the $\mathrm{iBoF}$ during summer (Dadswell et al. 


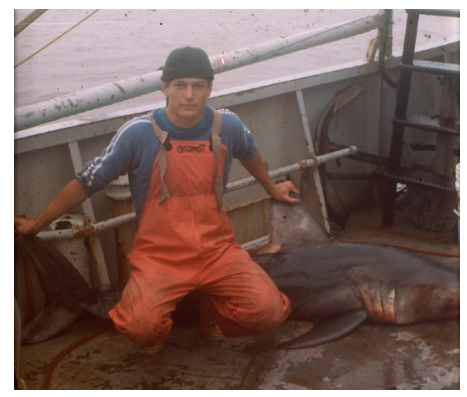

Fig 14 A $2.2 \mathrm{~m}$ TL Porbeagle shark captured in Cumberland Basin on August 5, 1980, while drift gill netting at night (photograph MJD).

1984a). They can be expected in Minas Basin and Passage from June to September. Estimated annual abundance is possibly about 100 individuals. They will occur near the surface at night and in deeper water during day and because of their large size would be at extreme risk of propeller turbine strike.

\section{Order: Squaliformes}

9. Smooth dogfish Mustelus canis (Mitchill, 1815). Marine, pelagic. Smooth dogfish are uncommon in the Bay of Fundy (Scott and Scott 1988) and has been reported only in the outer Bay during summer. They could occur in Minas Passage during summer mixed with spiny dogfish shark.

10. Greenland shark Somniosus microcephalus (Bloch and Schneider, 1801). Marine, pelagic and benthic. Greenland sharks are extremely rare south of the Gulf of St. Lawrence. A few specimens have been taken in the outer Bay of Fundy during winter (Templeman 1963).

Greenland shark are large $\left(6.4 \mathrm{~m} \mathrm{~L}_{\mathrm{T}}\right)$ but sluggish (Scott and Scott 1988). They feed on virtually all fishes including Atlantic salmon, as well as seals and carrion. They are common in the arctic and could be more common than known during winter in the Bay of Fundy (Scott and Scott 1988). There is a lack of fish studies in the Bay of Fundy during winter. Radiocarbon dating indicated a $5.5 \mathrm{~m} \mathrm{~L}_{\mathrm{T}}$ specimen was 392 years old, the oldest known vertebrate (Nielsen et al. 2016).

Greenland shark may occur in Minas Passage during winter but probably never more than sporadically. Because of their large size they would be at extreme risk to propeller turbine strike (Table 1). 
11. Spiny dogfish shark Squalus acanthias Linnaeus, 1758. Marine, pelagic and benthic. Dogfish shark were extremely abundant in the inner Bay of Fundy during summer until 2008 (Moore 1998, Wehrell 2005, Campana et al. 2008) but are now relatively rare (Dadswell et al. 2020). They occur in the outer Bay of Fundy all year (Scott 1988, Campana et al. 2008) but are found in Minas Basin only during April to October (Moore 1998).

During a survey in Minas Basin from July-October 1996, a total of 1115 dogfish shark were captured using baited long lines and drift grill nets (Moore 1998). Dogfish were predominately female (99.2\%) and lengths ranged from $64-113 \mathrm{~cm} \mathrm{~L}_{\mathrm{T}}$ for females and 74-86 $\mathrm{cm} \mathrm{L}_{\mathrm{T}}$ for males. Ages ranged from 10-34 years for females and 10-21 years for males. Dogfish shark are ovoviviparous, meaning eggs are laid and hatch internally with no placental attachment to the female (Scott and Scott 1988). Of female dogfish captured in Minas Basin during 1996, 56.1\% were reproductively mature and were carrying pups (Moore 1998). Litter sizes ranged from 1-11 embryos with a mean of 5.23 pups.female ${ }^{-1}$ which is similar to other reported North Atlantic populations (Dutton and Gioia 2019).

Dogfish shark that occur in Minas Basin during summer probably represent more than one stock. A total of 995 dogfish shark were tagged with numbered, external tags inside Minas Basin during 1996 (Moore 1998). Of these 33 (3.3\%) were returned by commercial fishers, scientific researchers and anglers after 93-995 days at large and traveling distances from 348-1049 km. A total of eight tags were recaptured off Massachusetts and Rhode Island, 17 between Grand Manan and Lurcher Shoal in the outer Bay of Fundy, five off southeastern Nova Scotia, one off northern Georges Bank and two in Minas Basin a year after tagging. Five of these tag returns came from dogfish captured in lobster traps after they were scavenging on lobster bait.

Dogfish shark feed on wide variety of marine organisms from jellyfish to other fishes, each other and carrion. They can be expected to occur at all depths in Minas Basin, mainly on bottom during day and at the surface at night but they usually rise to the surface at slack tide regardless of time of day (Dadswell, pers. obs.).

Commercial catches of 600-700 $t$, which would represent approximately 30,000-50,000 adults, were landed from Minas Basin annually up to 2004 (Dyer et al. 2005). Dogfish are taken by trawls 
(Fig 11), hand line (Dyer et al. 2005), weirs (Baker et al. 2014, Dadswell et al. 2020) and drift gill net (Dadswell et al. 1984a).

Dogfish will be migrating through Minas Passage during April to October. Inward movement would largely occur during April-July and outward movement from July to October. Based on an estimated fisheries mortality of dogfish shark for the Bay of Fundy (Campana et al. 2008) and the annual landings in Minas Basin (Dyer et al. 2005) approximately 1-2 million dogfish occupied the Basin each summer prior to 2005 and had to move in and out through Minas Passage. Their medium body length would make them susceptible to propeller turbine strikes especially since they are scavengers and would be attracted to turbine sites by the presence of wounded or dead fish.

\section{Order: Rajiformes 'skates and rays'}

All 'skates and rays', except the Atlantic torpedo, are strictly benthic fishes to the point where they commonly bury themselves in the substrate during day and emerge at night (Scott and Scott 1988). They are almost always found over sand, silt and mud bottoms. All species feed largely on benthic invertebrates except the Atlantic torpedo which is a fish predator. Some of the species listed below can be expected in Minas Passage during spring to fall but probably pass through rapidly because of the absence of their preferred substrate (AECOM 2009). They are abundant in trawl catches taken over soft bottom, especially at night (Wehrell 2005), but are usually not landed as commercial catch. Their benthic habitat preference will largely exclude them from possible tidal turbine impact.

12. Atlantic torpedo Tetronarce nobiliana (Bonaparte, 1835). Marine pelagic and benthic. Torpedo rays are a rare species on the Canadian Atlantic coast and are known only from the outer Bay of Fundy and Scotian Shelf during summer (Scott and Scott 1988). They attack fish and stun them with electric pulses. It may occur in Minas Passage during mid-summer.

13. Little skate Leucoraja erinacea (Mitchill, 1825). Marine, benthic. The little skate is known from the entire Bay of Fundy and occurs from the lower intertidal zone to offshore. This species is common in Minas Basin during summer (Wehrell 2005, Whidden 2015) and would be found in Minas Passage as well. Little skate is very difficult to distinguish from winter skate (Whidden 2015). 
14. Smooth skate Malcoraja senta (Garman, 1885). Marine, benthic. The smooth skate occurs in deeper water (30-60 m) of the outer Bay of Fundy all year (MacDonald et al. 1984). Deepwater habitat is absent in Minas Basin except in Minas Passage where there may be habitat for this species. It may also occur in Minas Channel, perhaps during winter.

15. Thorny skate Amblyraja radiata (Donovan, 1808). Marine, benthic. Thorny skate is common in the entire Bay of Fundy year around (Scott 1988). It is found in Minas Basin during summer (Wehrell 2005). It will occur over hard bottom (Scott and Scott 1988) and may be more common in Minas Passage than the other skates. Scott (1988) recorded it from Minas Channel.

16. Winter skate Leucoraja ocellata (Mitchill, 1815). Marine, benthic. Winter skate are very common in the entire Bay of Fundy all year and are found from the lower intertidal zone to offshore (Scott 1988). Skate egg cases (known as 'witches' purses') are commonly found on beaches in Minas Basin during summer.

This skate is abundant in Minas Basin during summer and is probably present during winter (Bousfield and Leim 1959, Wehrell 2005). Winter skate should be expected in Minas Passage but residency is probably short term. There is no directed fishery for them but they are sometimes landed for lobster bait. A total of 3753 winter and little skate were captured in the Bramber weir during 2012-2014 (Whidden 2015) and 2874 were captured in the same weir during April-July 2017 (Dadswell et al. 2020). Whidden (2015) estimated that the population size of winter and little skate in the Avon estuary of Minas Basin was approximately 29,500 adults.

17. Barndoor skate Dipturus laevis (Mitchill, 1818). Marine, benthic. Barndoor skates occur year round in the Bay of Fundy (Leim and Scott 1966) and in Minas Basin during most of the year (Bleakney and McAllister 1973) but is not abundant. The most recent verified occurrence of this species was at an Economy weir during 2013 (Fig 15). The barndoor skate is a large species and preys on both invertebrates and fishes (Scott and Scott 1988). It would occur in Minas Passage during migrations to and from the Bay of Fundy.

The barndoor skate is designated not at risk by COSEWIC (2010) and is not listed for protection by SARA. Although a larger ray its benthic habitat may make it less potentially vulnerable to tidal propeller turbines. 


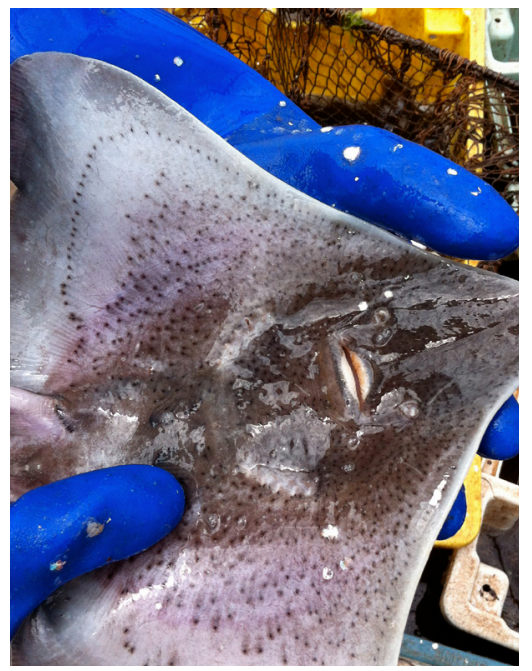

Fig 15 Barndoor skate captured in an Economy weir, June 2013 (photograph courtesy G. Nau, Acadia University).

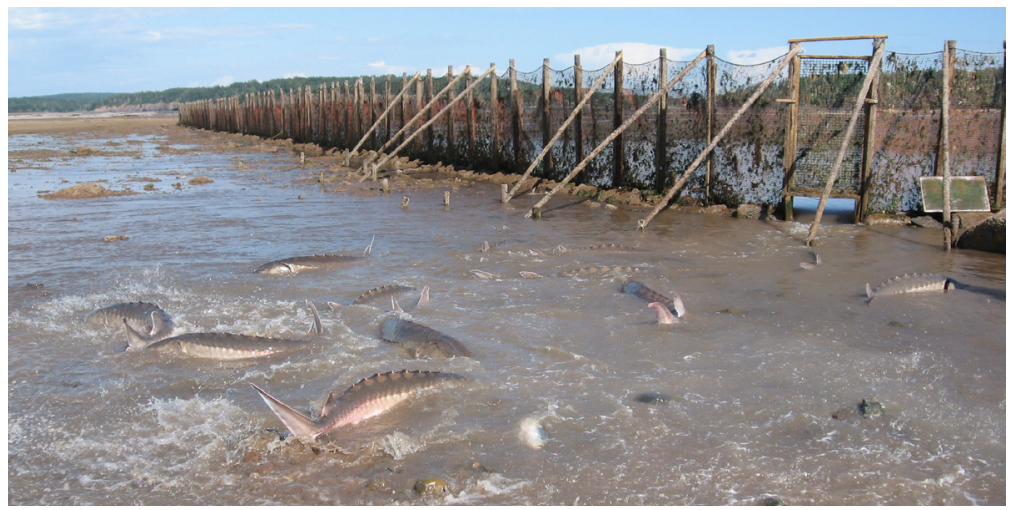

Fig 16 Catch of Atlantic sturgeon in the Walton weir, July 2008 (photograph courtesy S. Wehrell, Acadia University).

\section{CLASS: OSTEICHTHYES 'BONY FISHES'}

\section{Order: Acipenseriformes 'sturgeons'}

18. Atlantic sturgeon Acipenser oxyrinchus (Mitchill, 1814). Anadromous, benthic. The Atlantic sturgeon was the fifth most common fish captured by trawl in Minas Basin during a summer survey (Fig 16, Wehrell 2005). The aggregation in Minas Basin 


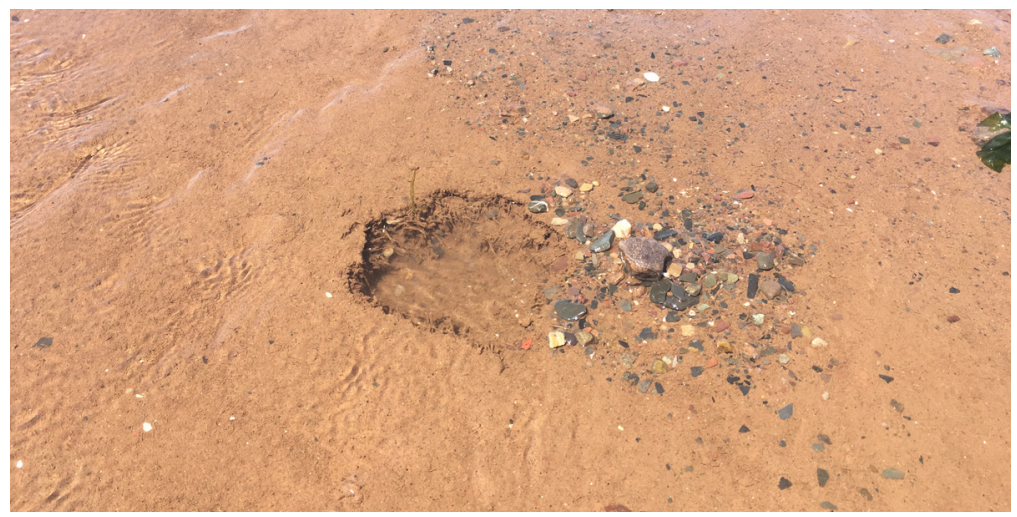

Fig 17 Atlantic sturgeon feeding trace on the tide flat at Bramber, July 2017. Note the circular shape of the hole in the sediment and the rejected large gravel which has fallen beside the hole (photograph MJD).

during May-October numbers about 10,000 individuals annually and consists of mainly juveniles of 1-1.5 $\mathrm{m} \mathrm{L}_{\mathrm{F}}$ with some adults up to $2.8 \mathrm{~m} \mathrm{~L}_{\mathrm{F}}$ (Dadswell et al. 2016). Adult Atlantic sturgeon are known to reach $4.6 \mathrm{~m}$ in length (Scott and Scott 1988).

Atlantic sturgeon feed on benthic invertebrates (worms, amphipods, McLean et al. 2013) and small fishes (sand lance, Scott and Scott 1988) in the subtidal and over the Minas Basin mud, silt and sand tide flats at high tide (McLean et al. 2014). They inhale the intertidal substrate and filter out the food items with their gills, rejecting the substrate (Fig 17, Pearson et al. 2007). They congregate in discrete 'sturgeon holes' at low tide. These locations are well known to fishers and are usually avoided (Dadswell, pers. obs.). Sturgeon are primarily benthic fish, but they often rise to the surface and make spectacular leaps to balance the gas content of their gas bladder (Logan-Chesney et al. 2017).

Inward migrating Atlantic sturgeon first appear mainly along the north shore of Minas Basin during April-May, move through the Basin to the Southern Bight during June-July then exit by Minas Passage during August-September (Dadswell et al. 2016, Stokesbury et al. 2016). An unknown portion of this aggregation consisting of young juveniles and adults over winters in freshwater tributaries of Minas Basin (Dadswell, pers. obs.).

Observations on the presence of ripe adults, young juveniles and the former distribution of commercial fisheries indicate that 
Atlantic sturgeon spawn in the Saint John, Annapolis, StewiackeShubenacadie and Avon Rivers in the Bay of Fundy and Minas Basin drainages (Leim and Scott 1966, Dadswell 2006, Dadswell et al. 2017, Dadswell et al. 2018). Juveniles remain in estuaries for 8-10 years until they are about $1 \mathrm{~m} \mathrm{~L}_{\mathrm{F}}$. After emigration to sea large juveniles and adults feed and migrate along east coast of North America from Virginia to Newfoundland. Tag returns (Dadswell et al. 2016) and DNA population discrimination (Wirgin et al. 2012) indicates the Minas Basin summer aggregation of Atlantic sturgeon are primarily from the Saint John R, NB (61\%), and Kennebec River, ME (38\%), with a few from the Hudson, Connecticut and James Rivers in the United States (US). One Atlantic sturgeon tagged on the spawning grounds in the Hudson River in 1994 was recovered at the Bramber weir in Minas Basin during 2015 after 21 years at large. Others tagged externally or with internal acoustic tags in Minas Basin were recorded at sea off New Jersey (2), New York (2), Cape Cod, MA (1) and Maine (4), and in the Penobscot River (2) ME, in the Saint John River (29) NB, and off the coast of Gaspe (1) QC (Dadswell et al. 2016). Twenty-seven adult sturgeon tagged acoustically in the Saint John River were detected entering or leaving Minas Basin a total of 47 times over periods up to four years (Taylor et al. 2016). Repeated movement through this region of potential tidal power development means that sturgeons are at risk to propeller tidal turbine impact. Also, since Atlantic sturgeon juveniles from the Saint John River, NB, will pass in and out of Minas Basin numerous times during the 10-15 years they spend at sea before maturing (Dadswell et al. 2016, 2017), they are at extreme risk from propeller tidal turbines.

The commercial fishery for Atlantic sturgeon in the Bay of Fundy was closed in 2002 except in the Saint John River (Dadswell et al. 2017). Formerly weir catches in Minas Basin were harvested and they were also commonly caught by trawlers. Atlantic sturgeon are known to be attacked in Minas Basin by great white sharks. Attack survivors are found with large tooth marks (Fig 18).

Atlantic sturgeon will be common to abundant in Minas Passage moving inward during May-June and outward during AugustSeptember and will occur throughout the water column (Stokesbury et al. 2016). Up to 10,000 individuals can be expected to pass through Minas Passage twice a year (Dadswell et al. 2016) and 


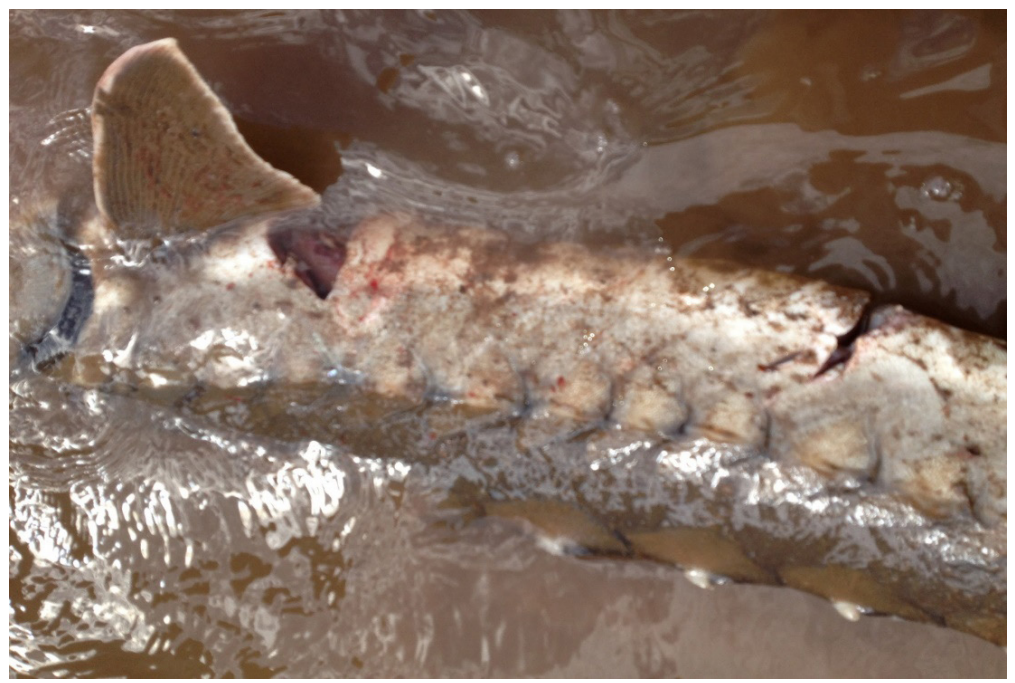

Fig 18 Atlantic sturgeon with great white shark tooth marks on the body captured in the Bramber weir in August 2013. Three sturgeon were taken in the weir that summer that had been attacked by great white shark (photograph courtesy D. Porter, Avondale, NS).

abundance can be expected to increase as sturgeon conservation efforts in Canada and the US take effect (Dadswell 2006). Like sharks, sturgeons have large body size which increases their chances of propeller turbine blade strike. A total of 24, known Atlantic sturgeon turbine mortalities have been recovered seaward of the tidal turbine at Annapolis Royal, NS since generation began there in 1985 (Dadswell and Rulifson 1994, Dadswell et al. 2018).

19. Shortnose sturgeon Acipenser brevirostrum Lesueur, 1818. Anadromous, benthic. The shortnose sturgeon is largely confined to the Saint John River estuary region of the Bay of Fundy (Dadswell 1979). The shortnose is a small species of sturgeon that only reaches a maximum length of $1.4 \mathrm{~m} \mathrm{~L}_{\mathrm{T}}$. It feeds primarily on various species of molluscs in fresh water and in warm estuaries (soft-shell clam).

The first verified record of a shortnose sturgeon in Minas Basin was taken June 29, 2013 in the Linkletter weir at Economy (Fig 19, Dadswell et al. 2013). It was a $73.7 \mathrm{~cm} \mathrm{~L}_{\mathrm{F}}$ adult and appeared to be in fine health. Shortnose sturgeon is listed as a 'species of concern' by SARA and since it has a relatively large body size is at moderate risk to propeller tidal turbines. 


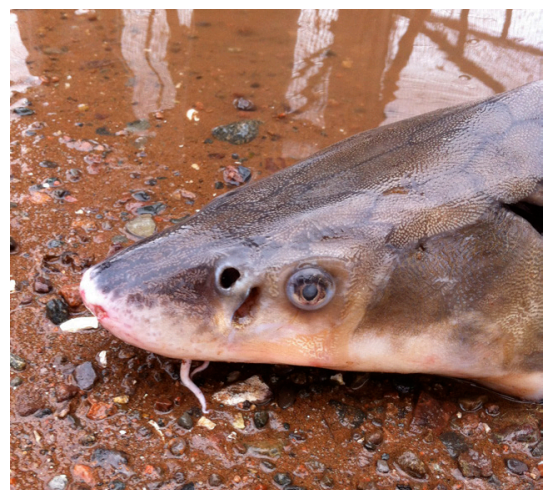

Fig 19 Head portion of a live shortnose sturgeon captured in the Economy weir on June 29, 2013 (photograph courtesy G. Nau, Acadia University).

\section{Order: Anguilliformes 'eels'}

20. American eel Anguilla rostrata (Lesueur, 1817). Catadromous, benthic. American eel is common to abundant in all tributaries of the Bay of Fundy and Minas Basin, in estuaries and along marine shorelines (Dadswell et al. 1984a). Adult eels spawn in the Sargasso Sea off the Bahamas and their leptocephalus larvae arrive off Canada after drifting north in the Gulf Stream (Scott and Scott 1988). The larvae metamorphose into glass eels in coastal waters then migrate onshore and into freshwater streams. Mainly females migrate upstream while males live in estuaries and along marine shorelines (Jessop 1996). American eel inhabit warm water ecosystems during summer but hibernate in marine and freshwater mud bottoms during winter. Eel are predatory, feeding on any and all invertebrates and fishes they can ingest. They also scavenge dead and dying organisms and can cause considerable harm to commercial fish catches. Females return to the sea at maturity after 7-10 years of growth and with the mature males migrate to the Sargasso Sea to spawn (Scott and Scott 1988). After spawning the adults die.

American eel support commercial fisheries at all life stages: as glass eels entering freshwater, as yellow eels during growth in freshwater and as silver eels while migrating back to the sea (Jessop 1996). Eels are an important, local fishery in the Minas Basin tributaries (Dyer et al. 2005). Eel populations around the North Atlantic are in severe decline and were assessed as threatened by COSEWIC (COSEWIC 2012). 
Glass eels (6-10 $\mathrm{cm} \mathrm{L}_{\mathrm{T}}$ ) will be abundant in Minas Passage and at the mouths of Minas Basin streams during April and May. Silver eels (80-100 $\mathrm{cm} \mathrm{L}_{\mathrm{T}}$ ) will migrate offshore through Minas Basin and Passage during August to October. The abundance of glass eels occurring in Minas Passage annually will probably be in the millions (Jessop 1996). Silver eels migrating seaward will possibly number in the range of 10,000-20,000 (Dyer et al. 2005). Eels are scavengers and would be attracted to a turbine sites by dead fish. With a body length up to $1 \mathrm{~m} \mathrm{~L}_{\mathrm{T}}$ they are at moderate risk to propeller turbines. The large 'silver' eels will probably be threatened less by propeller turbines since at this stage they do not feed (Scott and Scott 1988).

\section{Order: Clupeiformes 'herrings'}

A total of five species of clupeids utilize Minas Basin and its tributaries as foraging and/or spawning locations. As a group they are the most abundant and important commercial species occurring this the region.

The clupeids lack a lateral line and instead have evolved a highly specialized gas bladder that functions to enhance sound reception (Hoss and Blaxter 1979). The system includes two, thin-walled, forward projecting tubes from the gas bladder that interface with the otic bulla of the hind brain (Fig 20). Hydrostatic pressure flux during propeller turbine passage causes rapid expansion of the gas bladder and the tubes leading to the otic bulla causing hemorrhaging of the hind brain and death (Dadswell and Rulifson 1994). All clupeids are susceptible to high levels of propeller turbine impact

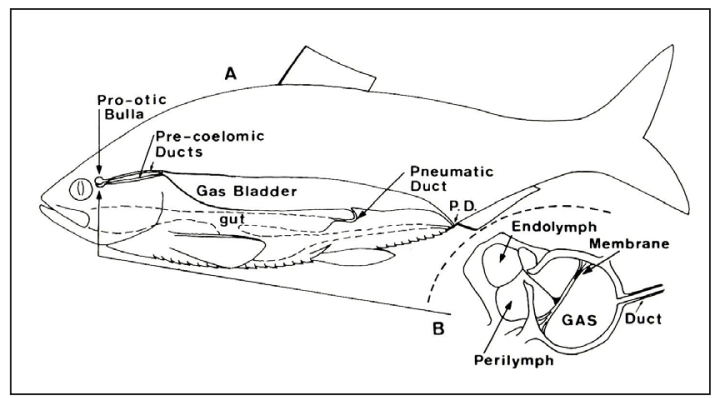

Fig 20 Gas bladder arrangement of a clupeid fish; A) gas bladder with precoelomic ducts leading to the pro-otic bulla of the hind brain, B) pro-otic bulla illustrating the tympanic membrane and gas chamber (adapted from Blaxter and Hoss 1979). 
(Stokesbury and Dadswell 1991, Dadswell and Rulison 1994, Gibson and Myers 2002, Dadswell et al. 2018).

Clupeids also school into dense 'bait balls' as a predator defense mechanism when under attack by pelagic fishes or cetaceans (porpoise, Gaskin 1985). If a school of herring or alosids make propeller turbine passage during a 'bait ball' situation many would be struck or killed by blade strike because of the dense packing of the school.

21. Blueback herring Alosa aestivalis (Mitchill, 1814). Anadromous, pelagic, planktivorous. The blueback herring, 'gaspereau' or 'river herring' are common to abundant in every tributary of the Bay of Fundy with spawning habitat (riffles and rapids) and access (no waterfall at tide head, Dadswell 1985). Adults spawn in freshwater during spring (May-June) after which they return to the sea (Scott and Scott 1988). Juveniles migrate to sea during August to October at an average length of $10 \mathrm{~cm} \mathrm{~L}_{\mathrm{F}}$ (Stokesbury and Dadswell 1989). Growth to maturity requires $4-5$ years at sea while the North American Atlantic stocks migrate north and south annually (Neves 1981). Blueback herring are facultative and filter feeding predators of zooplankton and neuston in the water column and exploit the highly productive secondary production of copepods, mysids, amphipods (Corophium) and sand shrimp (Crangon) in Minas Basin (Stone and Daborn 1987).

Blueback herring are extremely abundant in the pelagic zone of Minas Basin during summer. Mid-water trawl catches up to $345 \mathrm{~h}^{-1}$ of 'gaspereau' were made off Economy Point during late June 1983 (Bradford 1987). Stone (1985) found adult blueback herring were most abundant in Minas Basin gill net catches during July and in weirs during August and September. The summer aggregation in Minas Basin is derived from east coast stocks from as far south as North Carolina (Rulifson et al. 1987). During 1983-1986 a total of 18,958 gaspereau were tagged in weirs and off vessels in Minas Basin. From these tags there were a total of $74(0.39 \%)$ tag returns of which six were from Blueback herring caught in commercial fisheries including three from Albermarle Sound, NC 2,400 km distant, one from Maryland and two from Nova Scotia.

Blueback herring and alewife support large fisheries in the Gaspereau and Shubenacadie Rivers (Dyer et al. 2005) and in the intertidal weirs of Minas Basin (Rulifson et al. 1987, Dadswell et al. 2020). Adults and juveniles are taken in the intertidal weirs from 
April to December but the major movement through Minas Passage is probably into Minas Basin from March to July and exiting the Basin from July to November. The timing, spatial distribution and intensity of this movement requires research but the abundance of this population will be in the 10's of millions. During 2017 an estimated total of 350,000 gaspereau were captured in the Bramber weir (Dadswell et al. 2020).

22. Alewife Alosa pseudoharengus (Wilson 1811). Anadromous, pelagic, planktivorous. Like blueback herring, alewife is common to abundant in every tributary of the Bay of Fundy with spawning habitat (lakes and slow riverine areas) and access (no waterfall at tide head, Scott and Scott 1988). They spawn in fresh water during May-June after which the adults return to sea (Scott and Scott 1988). Juveniles migrate to sea during August to October at an average length of $10 \mathrm{~cm} \mathrm{~L}_{\mathrm{F}}$ (Stokesbury and Dadswell 1989). Growth to maturity takes 4-5 years at sea while stocks migrate north and south along the Atlantic coast annually (Neves 1981). Alewife, like blueback herring, is a facultative and filter-feeding predator on plankton and neuston in the water column (Stone and Daborn 1987). In Minas Basin they feed on plankton such as copepods and mysids and suspended benthic organisms like amphipods (Corophium) and shrimp (Crangon). Both alewife and blueback herring appear to be more adept than American shad at feeding in the turbid waters of Cobequid Bay. Their stomachs seldom contained more than 20-30\% detritus when captured in this location (Stone and Daborn 1987).

Alewife are extremely abundant in the pelagic zone of Minas Basin during summer where mid-water trawl catches of 'gaspereau' were up to $345 \mathrm{~h}^{-1}$ (Bradford 1987) and drift gillnet catches were up to $55.0100 \mathrm{~m}^{-3} .30 \mathrm{~min}^{-1}$ (Stone 1985). Like blueback herring the summer aggregation in Minas Basin is derived from many Atlantic coast stocks (Rulifson et al. 1987). Of the 18,958 'gaspereau' tagged in Minas Basin during 1983-1986 there were 58 tag returns of alewife; 18 from the commercial fishery in the Gaspereau River, NS, three from the commercial gill net fishery in the Shubenacadie River, NS, 34 from weirs and gill nets in Minas Basin, one each from commercial fisheries in the Tusket and Lahave Rivers, NS and one from a commercial trawler in Ipswich Bay, Massachusetts.

Alewife support commercial fisheries in the Gaspereau and Shubenacadie Rivers (Dyer et al. 2005) and from intertidal weirs of 
Minas Basin (Dadswell et al. 1984a, Dadswell et al. 2020). The commercial catch in the Gaspereau River ranged from 64-200 $t \mathrm{y}^{-1}$ and in the Shubenacadie River, 50-363 $t \mathrm{y}^{-1}$ during the period 1965-2000 (Dyer et al. 2005). The spawning population of alewife in the Gaspereau River ranges from 200,000-1 million adults annually (Gibson and Myers 2003). Alewife is captured in rivers from April to June and in intertidal weirs from April to December (Rulifson et al. 1987).

Alewife movement through Minas Passage is probably inward during March to July and outward from August to November. Like blueback herring, the timing, spatial distribution and intensity of this movement requires research but again the abundance will be in the 10's of millions of individuals from age- $0+$ to $6+$.

23. American shad Alosa sapidissima (Wilson, 1811). Anadromous, pelagic, planktivorous. American shad are common to abundant in all Bay of Fundy tributaries with spawning habitat (deep, rapid flow riverine sections) and access from the sea (no waterfall at tide head, Leim and Scott 1966). Adults spawn in freshwater during spring (May-July) after which they return to sea. Juveniles depart fresh water at $10 \mathrm{~cm} \mathrm{~L}$ F after 3-4 months of growth (AugOct, Stokesbury and Dadswell 1989). Shad mature after 4-5 years at sea then return to their natal river to spawn (Melvin et al. 1986). While at sea adults and juveniles migrate along the Atlantic coast from North Carolina in winter to the Bay of Fundy, the Gulf of St. Lawrence and Labrador in summer (Fig 2, MacDonald 1884, Dadswell et al. 1987). From three years of research in Minas Basin during which 5790 external tags were applied to shad (Fig 21) there have been a total of $368(6.3 \%)$ tag returns from as far south as the St. John's River, Florida and as far north as Labrador (Fig 22).

American shad of all ages are extremely abundant in the inner Bay of Fundy during May-October (Dadswell et al. 1983, 1984b) where the population consists of migrating stocks from all rivers on the Atlantic seaboard from Labrador to Florida. This mixture of stocks has been demonstrated with tagging studies (Dadswell et al. 1987), meristics and morphometrics (Melvin et al. 1992), otolith morphology (Williams 1985), parasites (Hogans et al. 1993) and DNA discrimination (Waldman et al. 2014). The coastal migratory population enters the Bay of Fundy along the Nova Scotia shore and follows the residual current pattern through the Bay departing on the New Brunswick shore (Fig 10). Shad become increasing dense as 


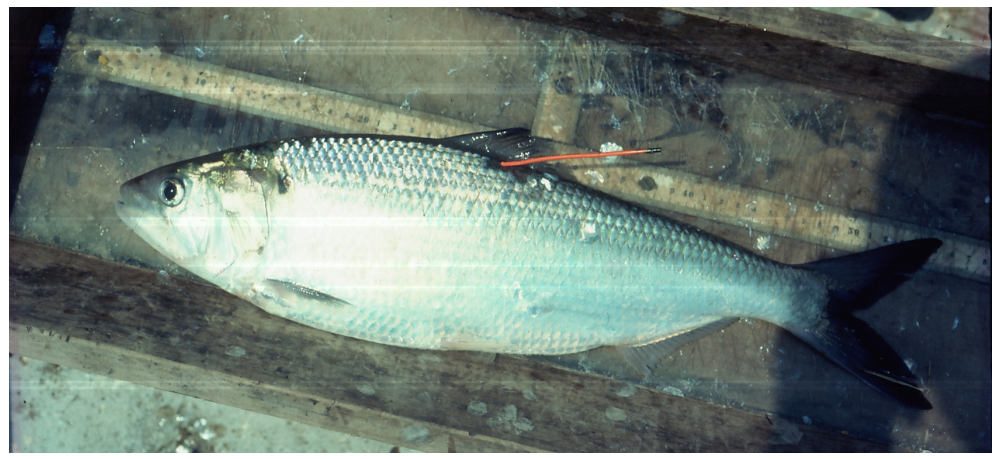

Fig 21 American shad captured in an experimental gill net in Minas Basin with an external, numbered spagetti tag applied under the dorsal fin. This particular shad was captured on July 8, 1982 and was recaptured on Dec 18, 1982 by a commercial fisher in the St. John's River, Florida after traveling an approximate distance of $2100 \mathrm{~km}$ over five months (photograph MJD).

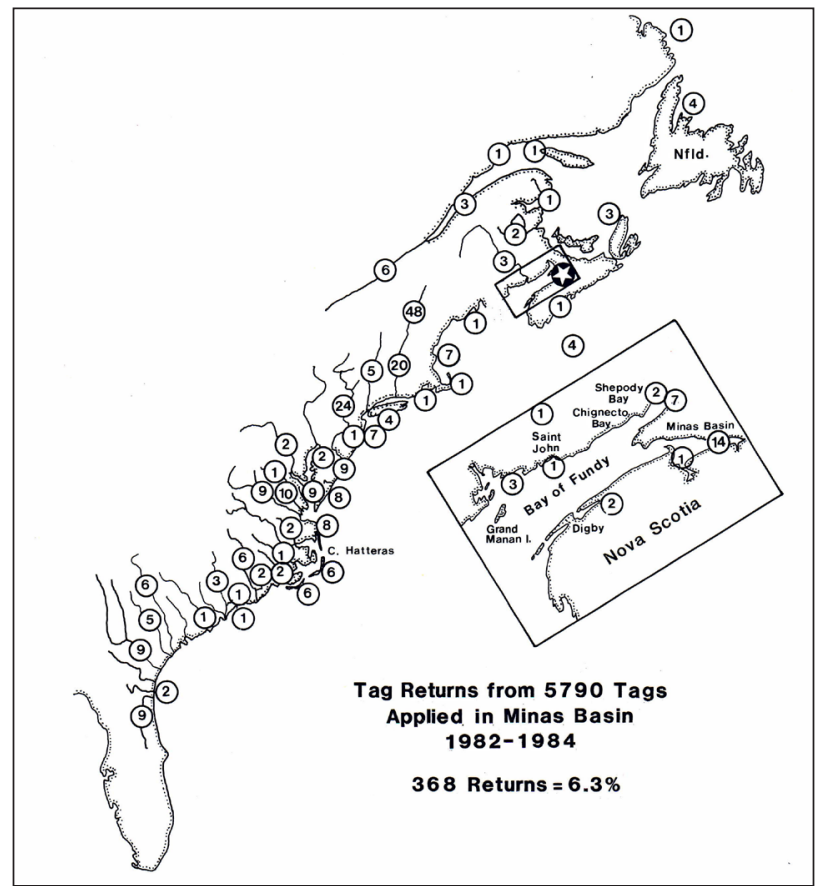

Fig 22 Tag returns (368) from American shad tagged in Minas Basin (5790) during 1982-1984 that were recaptured by commercial and recreational fishers along the east coast of North America. Shad were recaptured in the sea and in rivers using gill nets, weirs, trawls, haul seines and by angling. 


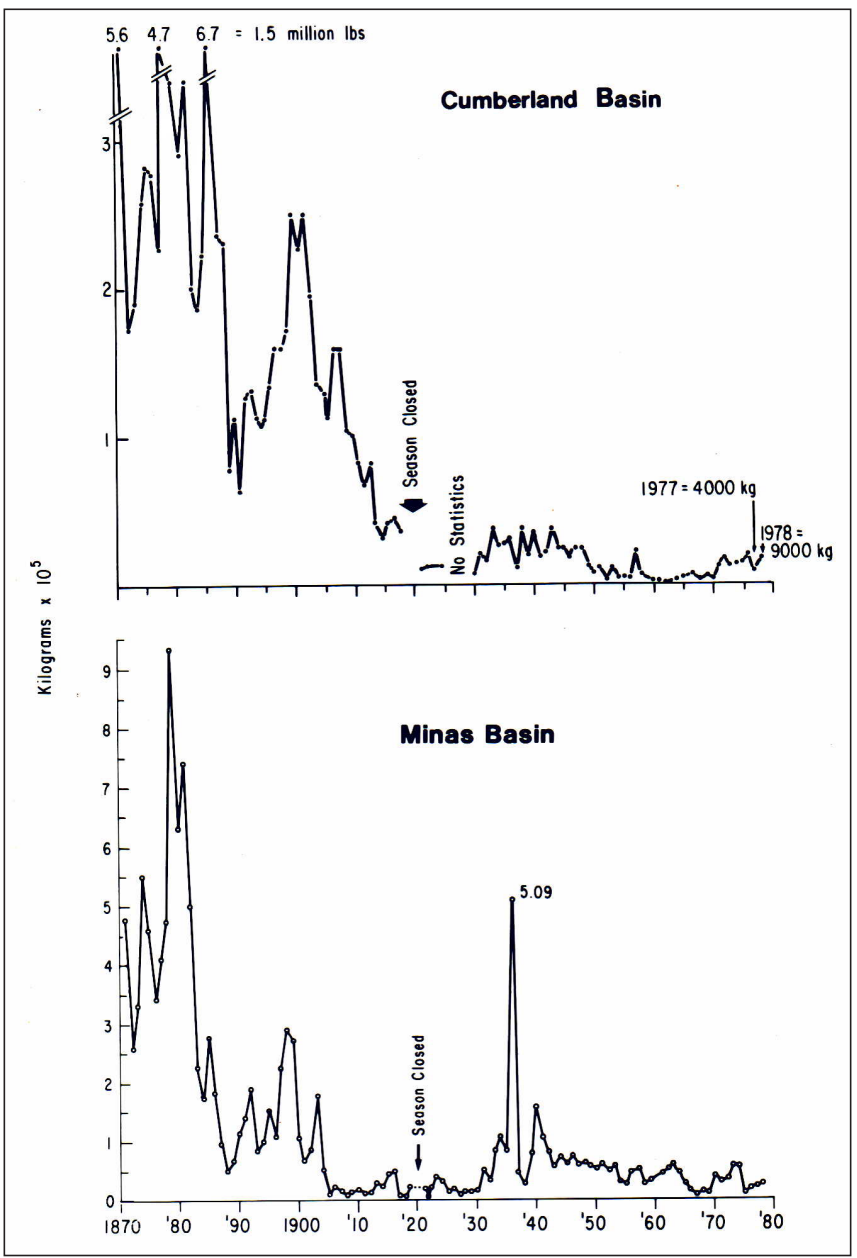

Fig 23 Commercial shad landings $\left(\mathrm{kg} \mathrm{X} \mathrm{10}{ }^{5}\right)$ in Cumberland and Minas Basins during 1870-1980. Note the difference in scale for the two localities. Landings collapsed after 1905. The season was closed from 1919-1921 but had no effect on landings. The Royal Commission established to study the collapse of the fishery was from 1921-1924.

they move into the embayments (Minas Basin, Cumberland Basin) at the inner end of the Bay of Fundy where the run effectively doubles back on itself. Population estimates for American shad in Minas Basin during 1982 indicated approximately 2.9 million adults were in the Basin during the 12-week period from June 1 to August 24 (Dadswell et al. 1984b). 
Research indicated that during the summer period when shad were in the turbid regions of Minas Basin they ingested a reduced daily ration because they were relatively unsuccessful at particle feeding in the turbid water (Themelis 1986). Stomachs from shad analyzed during this period contained plant detritus (up to $95 \%$ in Cobequid Bay) and only small amounts of food (copepods, mysids, shrimp, etc.). Individuals lost condition and muscle lipid content fell from a mean of $22.7 \%$ when the shad entered Cobequid Bay in early June to $16.3 \%$ when they were departing in late July. This seeming conundrum can be explained by the fact that the shad migration path in the Bay of Fundy and Minas Basin is apparently dictated by the direction of the residual currents rather than the availability of food (Dadswell et al. 1984b). When shad returned to the clear water in the Bay of Fundy stomach contents contained no detritus and were full of copepods and euphausiids (100\%). Their muscle lipid content rebounded to a mean of $28.9 \%$ by the time they reached Grand Manan Island at the outer Bay of Fundy during September (Themelis 1986).

Before 1900 the fishery for American shad in Minas and Cumberland Basins used to be the most important fishery in the Bay of Fundy (Prince 1912). Shad were taken with weirs and gill nets then salted and exported to the eastern United States. Annual catches ranged from 550-1100 $t \mathrm{y}^{-1}$ in Minas Basin (Fig 23). Their catchability in the $\mathrm{iBoF}$ is a direct result of the turbid water in these regions which decreases light penetration to shallow depths causing the shad to rise in the water column and become easily accessible to fishing gear (Dadswell et. al. 1983). The iBoF shad fishery collapsed after 1905 because of pollution and dam construction on their major spawning rivers in the US (Stevenson 1898). The collapse of the shad fishery in the iBoF lead to a Royal Commission investigation which resulted in some of the first scientific studies on shad and other fishes in Canada (Huntsman 1922, Leim 1924).

Present day commercial fisheries for shad exist in Minas and Cumberland Basin, and the Saint John, Shubenacadie and formerly the Petitcodiac and Avon Rivers in the Bay of Fundy (Leim and Scott 1966, Dadswell et al. 1984a). The shad gill net fishery in the Shubenacadie River varied from 10-60 $t$ annually between 1991 and 2001 (Dyer 2005). In Minas Basin shad are taken by intertidal weirs (Fig 12) and drift gill net (Fig 13) during May-August 
(Dadswell et al. 1984b). A total of 7,176 American shad were captured in the Bramber weir during 2017 (Dadswell et al. 2020).

Shad migrate inward through Minas Passage to Minas Basin from April-July and outward to the Bay of Fundy during July-October. The total population $(0+$ juveniles to adults) migrating through Minas Passage annually is possibly in the range of 10 million fish. Since the migration speed of feeding shad in the Bay of Fundy and Minas Basin was estimated at 3.0-3.5 km.d ${ }^{-1}$ (Dadswell et al. 1987), adult shad should make the crossing through Minas Passage in about 4-5 days. Smaller shad will probably take longer. The larger size of the adults (40-60 $\mathrm{cm} \mathrm{L}_{\mathrm{F}}$ ) makes them susceptible to propeller turbine mechanical strike impact (Dadswell and Rulifson 1994) and juveniles are susceptible to pressure flux, shear and cavitation (Stokesbury and Dadswell 1991). Experimental passage of post-spawning, adult shad through the Annapolis Royal tidal turbine during 1986 resulted in an estimated mortality of $21.3 \pm 15.2 \%$ (Dadswell and Rulifson 1994). Shad that migrate to Minas Basin during summer from rivers in the United States (Connecticut to Georgia) support a large fishery for flesh and roe in that region (Hilton et al. 2010). The impact of potential tidal power development on this fishery could be similar to the former impact on the $\mathrm{iBoF}$ shad fishery after 1905 by pollution and damming of rivers in the United States.

24. Atlantic menhaden Brevoortia tyrannus (Latrobe, 1802). Amphidromous, pelagic, planktivorous. Menhaden filter feed on phytoplankton and detritus (Durbin and Durbin 1975). Juvenile menhaden are found in large Bay of Fundy estuaries (Annapolis and Saint John Rivers, Stokesbury and Stokesbury 1993). Adults spawn in Minas Basin off Burntcoat Head in June (Fig 24, Dadswell, unpub. data) and some adults over winter in Kennebecasis Bay in the Saint John River estuary (Scott and Scott 1988). Occasionally, southern stocks from Chesapeake Bay penetrate into the Bay of Fundy during warm summers (Bigelow and Schroeder 1953).

The population that occurs in Minas Basin is apparently small. Seldom more than 10-20 individuals are taken in intertidal weirs during summer (July-August, Dadswell et al. 2020). The species is not fished commercially in Canada.

Adults would traverse Minas Passage inward to spawn in Minas Basin during May-June. Adults and juveniles would depart Minas Basin via Minas Passage in late summer. Population size 


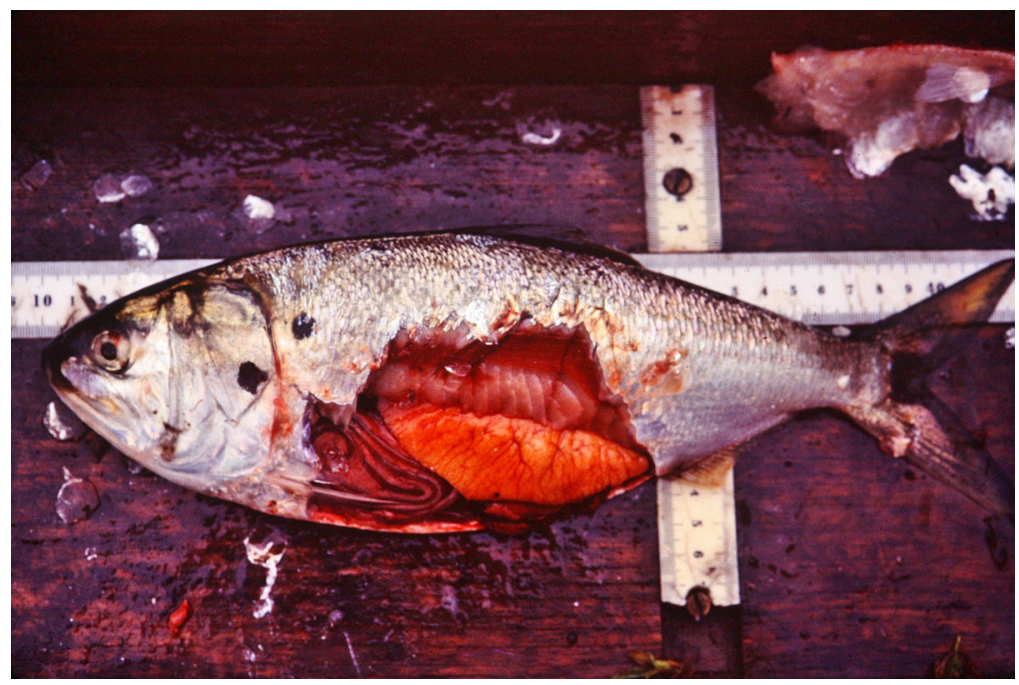

Fig 24 Gravid female American menhaden captured west of Burncoat Head just outside Cobequid Bay in June 1983. Note the bright orange eggs in the gonad. Spawning was to be within days (photograph MJD). A total of 12 ripe females and 14 ripe males were captured.

moving through Minas Passsage probably consists of a few hundred adults and 100 thousand + juveniles. Like all clupeids they would be impacted by strike, pressure flux, cavitation and shear during passage through propeller turbine draft tubes.

25. Atlantic herring Clupea harengus Linnaeus, 1758. Marine, pelagic, planktivorous. Herring are common to extremely abundant in all parts of the Bay of Fundy. Adults are marine, benthic spawners and stocks congregate on Lurcher Shoal off Yarmouth during October, in Scots Bay during August, and in Minas Basin during May to spawn (Bradford and Iles 1993). Larvae and juveniles (brit) form dense schools in the inner Bay of Fundy. Bradford and Iles (1993) found larval densities were highest inside Minas Basin (5.0-35.1 $\left.\mathrm{m}^{-3}\right)$. Abundance of herring larvae in Minas Passage during July were about $50 \%$ of the catches inside Minas Basin (Bradford 1987). One-half hour midwater trawl tows in Minas Channel caught 1000-10,000 brit during August and brit were abundant in other parts of the inner Bay of Fundy surveyed during February (Koeller 1979). Larger juveniles aggregate in Minas Basin during early summer (Fig 25, 'June herring', Perley 1852, Dadswell et al. 1984a, Bradford 1987). Adult herring schools occur at all depths in the water 


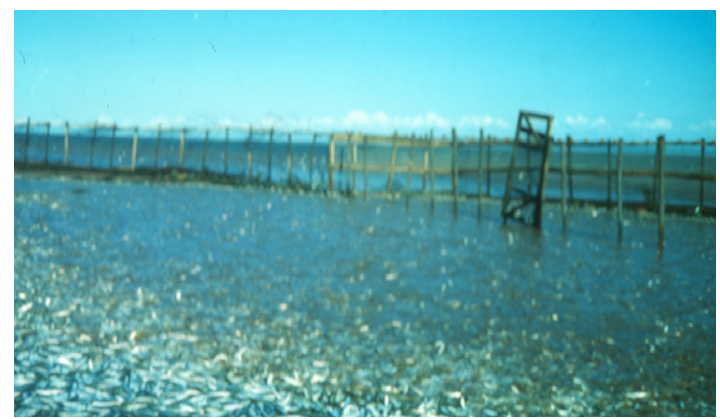

Fig 25 'June' Atlantic herring catch in a weir on the north shore of Cobequid Bay just inside Economy Point during June, 1983 (photograph MJD).

column but mainly near bottom during day and near surface at night. They form dense 'bait balls' when attacked by harbour porpoise (Gaskin 1985, Dadswell, pers. obs.). Herring are facultative and filter feeding planktivorous predators. Unlike other clupeid species adults generally avoid the turbid water in Cobequid Bay. Larvae and juveniles can maintain themselves in discrete areas near their spawning sites where productivity is high (Iles and Sinclair 1982). Based on observed abundance of larvae and juveniles three of these regions are inside Minas Basin near Economy Point, in Minas Passage and in Minas Channel (Koeller 1979, Bradford and Iles 1993).

Herring in Minas Basin, Minas Passage and Minas Channel are caught using intertidal weirs, intertidal gill nets and by purse seining (Bradford 1987). The weir at Bramber in Minas Basin caught an estimated 87,600 adult herring during April to June 2017 (Dadswell et al. 2020). The spawning stock biomass of the spring spawning group in Minas Basin is estimated to be $500 t$ which yields annual catches of about 50 t.yr ${ }^{-1}$ (Bradford and Iles 1993). The biomass of the summer spawning group in Scots Bay-Minas Channel is estimated at approximately 100,000 $t$ with an annual yield of 7,300 $t$ (R. Singh, DFO, pers.comm.). Atlantic herring support the largest fishery by biomass in the Bay of Fundy (CSAS 2007). The total allowable catch (TAC) has been set at 35,000 $t$ from the estimated total adult biomass of 500,000 $t$.

Herring of most life stages (larvae, juveniles and adults) are common to extremely abundant in Minas Passage during the entire year (Koeller 1979, Bradford and Iles 1993). Larvae are abundant during spring, summer and fall and brit are common during winter. 
Large juveniles and adults are abundant moving inward and outward through Minas Passage during March-June (Minas Basin stock adult spawners, 'June' herring juveniles). Adult spawners from the Scots Bay spawning stock are abundant in Minas Channel during July-September and large schools probably penetrate Minas Passage during this period. Like all clupeids they are susceptible to multiple forms of mortality during passage through propeller tidal turbines (Gibson and Myers 2002). Herring are extremely sensitive to pressure flux (Hass and Blaxter 1979).

\section{Order: Salmoniformes 'salmon and trout'}

26. Brook trout Salvelinus fontinalis (Mitchill, 1814). Anadromous, benthic/pelagic. Populations of brook trout occur in virtually every tributary of the Bay of Fundy from small brooks to large rivers (Scott and Scott 1988). Juveniles remain in fresh water but adults enter marine waters from April to August then return to over winter in freshwater. Brook trout support the most popular recreational fishery in Nova Scotia (McMillan et al. 2008).

Although brook trout are common to all tributaries of Minas Basin, Minas Passage and Minas Channel they are very seldom found during sampling in Minas Basin (Dadswell et al. 1984a, D. Porter, commercial fisherman, pers. obs). During weir surveys in Minas Basin since 1982, brook trout have rarely been encountered even when the weirs are situated within a kilometer or two of known brook trout streams (Walton River, Harrington River). The weir at Bramber only captured one brook trout during 2017 (Dadswell et al. 2020). Likewise, brook trout are seldom encountered during gill net sampling or angling in marine waters (J. Broome, Acadia University, pers. comm.). Brook trout probably occur only in the mouths of freshwater tributaries of Minas Passage and are probably in estuarine waters only from April to August. Their avoidance of the open marine habitat in this region should mean they will be little impacted by propeller tidal turbines.

27. Atlantic salmon Salmo salar Linnaeus, 1758. Anadromous, pelagic. There were once approximately $59 \mathrm{iBoF}$ tributaries which had stocks of Atlantic salmon but at least 7 of these are now extinct because of dams or causeways (Avon, Petitcodiac, Amiro 2003). The Petitcodiac River stock is now under restoration after removal of the causeway at Moncton. Inner Bay of Fundy stocks were assessed endangered by COSEWIC in 2003 and are now listed under 
Schedule 1 by SARA (no allowable take; CSAS 2004). There were Atlantic salmon runs in most tributaries of Minas Basin including the Shubenacadie-Stewiacke, Salmon, Gaspereau, Cornwallis and Avon Rivers and all tributaries along the north shore from Truro to Parrsboro. Many of these streams now lack populations because of causeways or the collapse of inner Bay of Fundy stocks (Gibson et al. 2003b).

Atlantic salmon spawn in fall in freshwater streams and most adults from $\mathrm{iBoF}$ rivers return to sea by December (Amiro et al. 2003). Juveniles (parr) remain in fresh water for 1-3 years then migrate to sea during May-June as smolts. Adults remain at sea for 1-4 years migrating in the North Atlantic in regions with water temperatures of 4-10 $C^{\circ}$ (Dadswell et al. 2010). Adults home to natal $i B o F$ rivers from August to November. Salmon runs in most Minas Basin rivers consisted of $1 \mathrm{SW}$ adults $\left(50-60 \mathrm{~cm} \mathrm{~L}_{\mathrm{F}}\right)$ and returning kelts (multiple spawners, Huntsman 1958, Amiro et al. 2003).

Formerly Minas Basin had both commercial and recreational salmon fisheries. The commercial fishery was closed in 1984 (Dadswell et al. 1984a) and angling in 1992 (Amiro et al. 2003). Salmon were taken by the commercial fishery in Minas Basin by drift gill nets and intertidal weirs (Huntsman 1958). Catches from 1900-1984 varied between 1-4t $\mathrm{y}^{-1}$ (Dadswell et al. 1984a). Angling occurred in most Basin tributaries. Formerly, angling catches in the Shubenacadie-Stewiacke River basin were from 500-1000 $\mathrm{y}^{-1}$ (Morantz 1978) but catches in other tributaries seldom exceeded $100 \mathrm{y}^{-1}$ (Amiro et al. 2003). The estimated population of returning adults to Minas Basin tributaries was around 40,000 as recently as 1989 but only 250 were counted in 1999 (Amiro 1999). Similarly, parr densities have declined in all tributaries (Gibson et al. 2003b). The smolt run size in the Gaspereau River during 2009 was estimated to be about 5,600 fish but only 1,100 were wild smolts, the rest were stocked hatchery fish (Quinn 2010).

Atlantic salmon smolts can be expected migrating seaward through Minas Passage during May to July. Atlantic salmon adults will occur in Minas Passage from June to December. Although most adults will be from Minas Basin tributaries some are migrants from other Bay of Fundy stocks, the US (Connecticut and Penobscot Rivers, Meister 1984) and the Gulf of Saint Lawrence (Miramichi River, Saunders 1969). Pre-spawning adults will be migrating 
inward during June to November. Kelts (post-spawning salmon) will be moving seaward during November-December.

Smolt migration speeds at sea average $6-26 \mathrm{~km} \cdot \mathrm{d}^{-1}$ (Lacroix and McCurdy 1996) and most smolts would be expected to clear Minas Passage in one to two days unless countered by gyre currents (Lacroix 2008). Adult salmon make from $20-50 \mathrm{~km} \cdot \mathrm{d}^{-1}$ when migrating at sea (Meister 1984, Hansen et al. 1993) and movement through Minas Passage would be rapid.

Numbers of migrating smolt will probably be in the range of 10,000 to 20,000 annually (wild and hatchery fish) and numbers of migrating adults at present population levels will probably be less than 500 individuals inward and perhaps half of that outward as kelts. If, however, iBoF salmon stocks rebound in the future 20,000 to 40,000 adults could make the passage each year and the number of smolt could increase up to a million annually.

Adult salmon, because of their relatively large size, will be at risk of mechanical strike from propeller, tidal turbines (Dadswell and Rulifson 1994). While occupying a fixed, mid-water trawl survey site at the mouth of Cobequid Bay during June 1983 an adult salmon was cut in half by the propeller of the $26 \mathrm{~m}$ research vessel which was under power to relieve strain on the anchor (Dadswell, pers. obs.). The salmon was recovered in the research net in two pieces. Salmon smolts are susceptible to shear damage during passage through propeller turbine draft tubes (Dadswell and Rulifson 1994).

28. Brown trout Salmo trutta Linnaeus, 1758. Anadromous, benthic-pelagic. Brown trout were introduced from Europe during the late 1800's and early 1900's and have become well established in Minas Basin rivers especially the Cornwallis and Shubenacadie (Leim and Scott 1966). Their life history is similar to Atlantic salmon except brown trout remain at sea only from May to September and do not move far from their natal river. Brown trout are seen more often in intertidal weirs in Minas Basin than brook trout and are sometimes captured in drift gill nets (Dadswell et al. 1984a). A total of nine brown trout were captured in the weir at Bramber during 2017 (Dadswell et al. 2020).

There are few rivers with brown trout near Minas Passage and this species should only occur sporadically offshore in the Passage. If present it would be from May to September. Their propeller tidal turbine risk is similar to that of Atlantic salmon. 
29. Coho salmon Oncorhynchus kisutch (Walbaum, 1792). Anadromous, pelagic. Coho salmon were introduced into Maritime rivers from western Canada during the early 1900's but most populations have since died out (Scott and Scott 1988). Coho were common in the Bay of Fundy during the 1980's when large numbers were being stocked in New Hampshire, US and adults migrated north to the Bay of Fundy (Martin and Dadswell 1983). The New Hampshire stocking was terminated in the 1990's. There was also a spawning population in the Cornwallis River which resulted either from the New Hampshire introductions or hatchery escapees (Martin and Dadswell 1983).

Coho life history is somewhat similar to Atlantic salmon except they migrate to sea at a younger age and smaller size (after one year in the river). No adults have been recorded in Minas Basin since the late 1980's and the population in the Cornwallis River may be extirpated. They may be encountered rarely in Minas Basin and Passage. There was an angling fishery for coho in the Cornwallis River.

30. Rainbow trout Oncorhynchus mykiss (Walbaum, 1792). Anadromous, pelagic. Rainbow trout were introduced to the Maritimes from western Canada in the late 1800's and introductions continue into the present since rainbow trout in aquaculture operations often escape (Scott and Scott 1988). Their life history is similar to brown trout. Rainbows migrate into the sea in spring, feed in salt water during summer and return to fresh water during fall for over wintering. The species is not common in $\mathrm{iBoF}$ tributaries but occurs in some. A few should be expected sporadically in Minas Channel.

\section{Order: Osmeriformes 'smelts'}

31. Rainbow smelt Osmerus mordax (Mitchill, 1814). Anadromous, pelagic. Rainbow smelt are extremely abundant and ubiquitous in all regions of the inner Bay of Fundy (Dadswell et al. 1984a). Spawning stocks occur in all rivers and brooks with access from the sea and spring arrivals of ripe adults are close to the same time period every year in each stream. Two examples are: spawning smelt appear in the Gaspereau River on the south side of Minas Basin during late April and in the Portapique River on the north side during the second week of May (Dadswell, pers. obs.). Spring arrival of spawning populations are exploited by recreational fishers using dip nets but there is no directed commercial fishery in Minas Basin. After the adhesive eggs hatch in fresh water the larvae drift into 
the sea and there are dense concentrations of pelagic larvae in the Minas Basin from May to August (Roberts 1987, Bradford 1987). Juveniles and adults occur in the water column and along shorelines (Dadswell et al. 1984a). Smelt mature in their second summer of life and seldom live past age-4 (Scott and Scott 1988). They are voracious predators and eat virtually anything smaller than themselves. There is an angling fishery for them in Minas Basin off wharfs and through the ice during fall and winter (D. Porter, pers. comm.).

During April to July 2017, a total of 94,000 smelt were captured in the Bramber weir (Dadswell et al. 2020). Catches of 10-1000 smelt were taken in the weir during daytime low tides. Catches during low tide at night seldom exceeded ten fish. Similar catches were recorded in the Five Islands weir during 2013 (Baker et al. 2014).

Surveys for smelt have never been carried out in Minas Passage but they should be abundant especially near shore. They can be expected to occur in Minas Passage year round but could be more abundant during winter when colder water in Minas Basin could cause seaward migration from the Basin. Because of their small body size and high abundance their population would be at little risk from tidal turbines.

32. Capelin Mallotus villosus (Müller, 1776). Marine, pelagic, planktivorous. Capelin spawn in the sand of marine beaches at the high tide level during May-June (Scott and Scott 1988). They have only been captured occasionally in the Bay of Fundy (Tibbo and Humpreys 1966) but there may be one stock that spawns on beaches of the Fundy National Park (Perley 1852). Capelin probably rarely occur in Minas Passage but schools of this subarctic fish may be present during winter. They have never been taken in Minas Basin (Bleakney and McAllister 1973, Dadswell et al. 1984a, Dadswell et al. 2020).

\section{Order: Lophiiformes 'goosefishes, anglers'}

33. Monkfish Lophius americanus Valenciennes, 1837. Marine, benthic. Monkfish are common but not abundant throughout the Bay of Fundy and in Minas Basin (Bleakney and McAllister 1973, Scott 1988). Monkfish feed largely on fishes especially flounders and follow the flounder migration to the inner Bay of Fundy during summer. They can grow to a size of $1.0 \mathrm{~m} \mathrm{~L}_{\mathrm{T}}$.

This fish is a benthic, lay-in-wait predator that uses a modified dorsal fin spine over the snout as a lure-like structure to attract 
prey (the illicium and esca are the specialized structures). It moves onto the intertidal zone at high tide while pursuing flounders and is often stranded on tide flats by the rapid fall of the tide (Bleakney and McAllister 1973, Dadswell, pers. obs.).

Monkfish are taken in small numbers as by-catch in the groundfish and scallop fisheries and in intertidal weirs in Minas Basin and Scots Bay (Beanlands et al. 2000). During 2017 four monkfish were caught at the Bramber weir (Dadswell et al. 2020). The population in the Bay of Fundy is stable and landings from 1990 to 2000 averaged $700 t \mathrm{y}^{-1}$ (Beanlands et al. 2000).

Monkfish will be passing into and out of Minas Basin via Minas Passage from April to October. They will be present in small numbers and will probably remain on or near the bottom and in near shore locations. Their risk from propeller tidal turbines is low.

\section{Order: Gadiformes 'codfishes'}

34. Fourbeard rockling Enchelyopus cimbrius (Linnaeus, 1766). Marine, benthic. Rockling are a small, cod-like fish that are common over mud and gravel bottom in the outer Bay of Fundy (MacDonald et al. 1984). They are rare inside Minas Basin and adults have only been observed twice in the intertidal zone, once by Bleakney and McAllister (1973) and again in 2018 (Fig 26, E. Porter, pers. comm.). They prefer cooler water (Scott and Scott 1988) and may be more common in Scots Bay and Minas Channel. Daborn (1984) reported their larvae were abundant in neuston samples from Minas Channel $\left(15.41000 \mathrm{~m}^{-3}\right)$. Adults are small and seldom exceed $30 \mathrm{~cm} \mathrm{~L}_{\mathrm{T}}$.

Rockling adults should be rare in Minas Passage since the bottom consists primarily of scoured rock (AECOM 2009). Rockling larvae are abundant near the surface from May-August during some years. The potential for harm from hydrokinetic turbines is minimal.

35. Atlantic cod Gadus morhua Linnaeus, 1758. Marine, benthic-pelagic. Cod were once very common in the entire Bay of Fundy but stocks are now depleted (CSAS 2006). Landings in the Bay of Fundy fell from 24,000 $t$ in 1990 to $3800 t$ by 2006 . Overfishing is probably the root cause but some are suggesting an oceanographic regime change occurred (Bundy and Fanning 2005). Recruitment to the stock has been poor since 1990 and the spawning stock biomass remains low, so the allowable catch was set at $1800 t$ in 2008 (Clark and Emberley 2009) but is now only $825 t$ (D. Themelis, DFO, pers. comm.). 


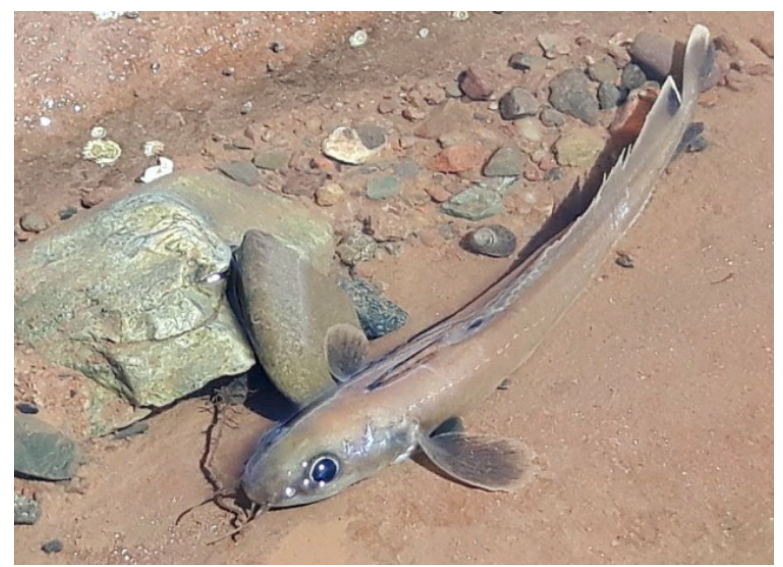

Fig 26 Fourbeard rockling found in a tide pool on the intertidal zone off Burntcoat Head during June, 2018 (photograph courtesy E. Porter, Avondale, NS).

Cod are found in Minas Basin and Minas Channel only during the seasonal coldwater period when temperatures are from 3-10 ${ }^{\circ} \mathrm{C}$ (November to June; Scott 1987). Cod feed on invertebrates and fishes and will follow alosid spawning runs into the low salinity water of estuaries (Dadswell, pers. obs.). Cod were formerly caught commercially in Minas Basin by long lines set in the intertidal zone (Dadswell et al. 1984a) but the fishery is now closed. They are taken in intertidal weirs occasionally (Dadswell et al. 1984a, Dadswell et al. 2020) and as by catch in the flounder trawl fishery during June-July (Wehrell 2005). During 2004 six cod were taken in trawl surveys in Minas Basin and during 2017 a total of six were taken in the Bramber weir.

Cod can be expected in Minas Passage from November to July but are probably most common during March-May. It will occur on bottom and in mid water. Until the stock rebounds numbers will be low and probably fewer than a thousand will pass in and out of Minas Basin during a year. Adults, because of their size, will be at risk from propeller tidal turbines.

36. Haddock Melanogrammus aeglefinus (Linnaeus, 1758). Marine, benthic. Haddock were once very common in Bay of Fundy during summer from Scots Bay to Lurcher Shoal while on feeding migrations from Brown's Bank and the Gulf of Maine (Perley 1852, Scott 1988). After 1965, however, haddock became rare in the inner 
Bay of Fundy because of overfishing and poor recruitment (Scott 1987, Frank 1992). Before the decline of the haddock stock in 1965 landings in the $\mathrm{iBoF}$ were substantial but all landings in the Bay of Fundy continue to remain low and were only 5-8 $t \mathrm{y}^{-1}$ from 19902005 (Dyer 2005). The lack of haddock in the iBoF, however, seems unexplained since the Scotian Shelf-Bay of Fundy stock is healthy and has grown to a large size. The spawning stock biomass was $33,770 t$ in 2016 and is expected to increase to $100,000 t$ because of the highest level of recruitment on record in 2013 (DFO 2017a). Perhaps haddock will once again be abundant in the $\mathrm{iBoF}$.

Haddock only occur in the Bay of Fundy during summer where they feed over mud bottoms on small invertebrates. In winter they are offshore on the Scotian Shelf (MacDonald et al. 1984, Scott 1988). Haddock have never been recorded from Minas Basin (Huntsman 1922, Dadswell et al. 1984a) even though they were once abundant in Scots Bay (Scott 1987). Their absence from Minas Basin could be explained because of a lack of proper substrate and because they select temperatures of 4-8 Co (Scott and Scott 1988). Haddock will probably seldom occur in Minas Passage because of higher summer temperatures and a lack of preferred feeding substrate (AECOM 2009).

37. Silver hake Merluccius bilinearis (Mitchill, 1814). Marine, benthic and pelagic. Silver hake are common in the Bay of Fundy during summer from Scots Bay to Lurcher Shoal (Simon and Comeau 1994). Silver hake are often captured in intertidal weirs in Scots Bay and Minas Basin but never in large numbers (Leim 1924, Dadswell et al. 1984a). The weir at Bramber in Minas Basin caught 384 silver hake during April-July, 2017 (Dadswell et al. 2020). No directed fishery exists in the Bay of Fundy because of low abundance and a lack of markets in North America (Simon and Comeau 1994).

Silver hake can be expected in Minas Passage during July to September but numbers will be low, probably only a few thousand fish. They migrate predominately in the water column (Scott and Scott 1988) so will be at risk from propeller tidal turbines.

38. Red hake Urophycis chuss (Walbaum, 1792). Marine, benthic. Red Hake is common in all regions of the Bay of Fundy, especially so in the outer Bay where juveniles are commensal with sea scallops during the first year of their life (Markle et al. 1982, 
Garman 1983). Juveniles (age-1) are common to abundant in Minas Basin intertidal weir catches during July after leaving their scallop hosts and while on migration around the Bay of Fundy to the Scotian Shelf (Dadswell, pers. obs.). During 2017 the weir at Bramber caught over 7000 juvenile hake (Dadswell et al. 2020). Adult red hake are rare inside Minas Basin and usually only occur during the coldwater season (Dadswell et al. 2020).

Juvenile red hake (5-15 $\mathrm{cm} \mathrm{L}_{\mathrm{T}}$ ) will be abundant in Minas Passage during June-August as they migrate from their scallop hosts and pass through the $\mathrm{iBoF}$. Movement inward to Minas Basin will be during June, outward movement, during August. There will be large numbers of juveniles migrating, probably 100's of thousands, but since they are a small benthic fish and will remain near bottom they are probably at low risk from propeller tidal turbines. They could, however, be impacted by turbines in tidal lagoons.

39. White hake Urophycis tenuis (Mitchill, 1814). Marine, benthic. White hake are common throughout the Bay of Fundy especially over mud bottom of the outer bay (Scott 1987, Simon and Comeau 1994). Juveniles (5-15 $\left.\mathrm{cm} \mathrm{L}_{\mathrm{T}}\right)$ are common in Cumberland Basin during June-August (Markle et al. 1982) and adults have been taken in trawls in Minas Channel (Scott 1988). White hake are tolerant of reduced salinity and there are small populations in Kennebecasis Bay of the Saint John River (Scott and Scott 1988) and Minas and Cumberland Basin (Dadswell et al. 1984a).

In Minas Basin they are commonly captured in small numbers by intertidal weirs and as by catch in flounder trawls (Dadswell et al. 1984a, Wehrell 2005, Dadswell et al. 2020) but there is no directed fishery. Individuals observed in the Minas Basin were mostly juveniles or small adults. White hake probably occur in Minas Passage from April to October during movement into and out of Minas Basin. Their degree of risk from propeller tidal turbines is probably minimal since they are primarily a benthic species.

40. Spotted hake Urophycis regia (Walbaum, 1792) Marine, benthic. A stray from deep water in the Gulf of Maine, usually found offshore (Scott and Scott 1988). The first record for this species in Minas Basin was from the Bramber weir on June 23, 2017 (Fig 27). It was a $28 \mathrm{~cm} \mathrm{~L}_{\mathrm{T}}$ adult. Two more were captured at the same weir during May, 2018 (D. Porter, pers. comm.). 


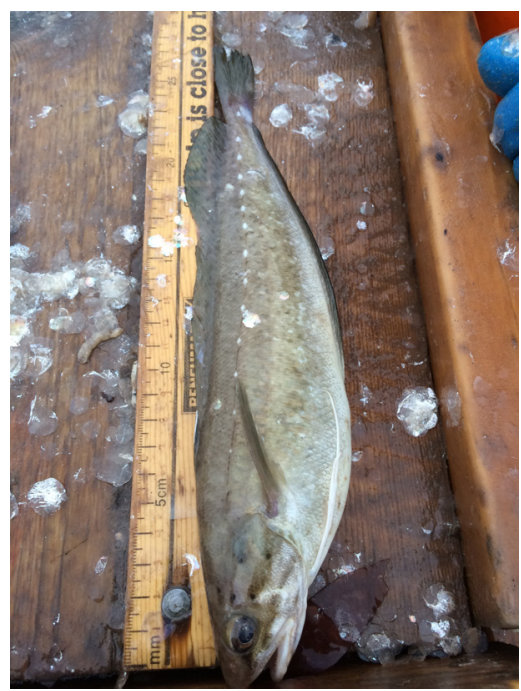

Fig 27 Spotted hake captured in the Bramber weir during June, 2017 (photograph courtesy of E. Porter, Avondale, NS).

41. Longfin hake Urophycis chesteri (Goode and Bean, 1878). Marine, benthic. Another stray from offshore usually found at depths of 200-1000 m (Scott and Scott 1988). The first record for this species in Minas Basin was a $11 \mathrm{~cm} \mathrm{~T}_{\mathrm{L}}$ specimen taken in the Bramber weir during April 2017 (Dadswell et al. 2020).

42. Pollock Pollachius virens (Linnaeus, 1758). Marine, pelagic. Pollock is common to abundant in the outer Bay of Fundy (Scott 1988), but rare in the inner Bay except in Minas Passage where there has been a hand line fishery since the early 1800's (Perley 1852, Dyer 2005). Juveniles recruited from spawning in the southern Gulf of Maine (Trippel et al. 1997) form large schools inshore around the Bay of Fundy over gravel and pebble beaches during spring then aggregate around wharfs during summer-fall ('harbour pollock', Rangely and Kramer 1995). Pollock are a pelagic predator that feed extensively on euphausiids. Their abundance and growth rates have been declining in recent years (Trippel et al. 1997).

Pollock are taken commercially and recreationally using trawls, long lines, gill nets and hand lines. Aggregations of adults occur in regions of dynamic flow and upwelling, around reefs and in channels (Scott 1987). The commercial fishery in the Bay of Fundy was landing 40,000 $t \mathrm{y}^{-1}$ during the 1980's (Trippel et al. 1997) but 
landings declined to $4500 t$ by 2004 (Dyer et al. 2005). Pollack have been recorded only once inside Minas Basin when one specimen was captured at the Bramber weir in 2017 (Dadswell et al. 2020).

Pollock are taken by hand line in Minas Channel and Minas Passage from April to October (J. Barkhouse, commercial fisher, pers. comm.). They possibly move into and out of Minas Passage with the tides. Abundance is low at present (Simon and Comeau 1994) but could increase if the stock rebounds. Current numbers are probably in the thousands to 10's of thousands. Pollock grow to $1.0 \mathrm{~m} \mathrm{~L}_{\mathrm{T}}$ and $20 \mathrm{~kg}$ in weight. Since they are pelagic and of relatively large size they are at risk from axial flow, hydraulic lift propeller tidal turbines.

43. Atlantic tomcod Microgadus tomcod (Walbaum, 1792). Anadromous, benthic. Tomcod are extremely abundant in turbid regions of inner Bay of Fundy, especially Cobequid Bay and Cumberland Basin. Dadswell and co-workers (1984a) caught from 10-105 individuals in each 5-minute seine haul and a Joli-Seber population estimate for one small cove was $122,000 \pm 39,000$ tomcod. They are also abundant along beaches in remainder of the Bay of Fundy during winter (Dadswell per. obs.). They are a small fish seldom exceeding $24 \mathrm{~cm} \mathrm{~L}_{\mathrm{T}}$ and age-4 (Dadswell et al. 1984a). Over the mudflats in the $\mathrm{iBoF}$ they feed on benthic organisms especially the amphipod, Corophium volutator.

Tomcod spawn in freshwater streams close to the head of tide in December and January hence the common name 'frost fish' in English or 'punamuiku' in Mi'kmaq (Scott and Scott 1988). There is a huge run of spawning tomcod that enters the Shubenacadie River during December and attracts large numbers of bald eagle to the river (Reid 1982). Eggs are adhesive, attach to the substrate and hatch in about a month (Peterson et al. 1980). The larvae are swept into the sea and dense concentrations of pelagic larvae occur in Cobequid Bay and Minas Basin during February to August (Bradford 1987) after which the juveniles settle and move inshore (Dadswell et al. 1984a). Tomcod are commonly found marooned in the intertidal zone (Bleakney and McAllister 1973).

There is a small commercial weir fishery for tomcod in Minas Basin. During April-July 2017 the Bramber weir captured over 68,000 individuals (Dadswell et al. 2020). Their winter spawning runs are an important food resource for the Mi'kmaq.

Adult tomcod will occur along the shoreline of Minas Passage, especially in winter and pelagic juveniles will be abundant offshore 
in the Passage during February to August. Numbers of pelagic juveniles during this period will probably number in the 10's of millions. Because they have a physocleistic gas bladder and cannot release gas from it quickly (Moyle and Cech 1996), tomcod larvae may be susceptible to pressure flux mortality during passage through propeller turbine draft tubes in Minas Passage, but due to their inshore, benthic behavior juvenile and adult tomcod are unlikely to be impacted. Juveniles and adults will be impacted if propeller turbines are used for power generation in tidal lagoons.

\section{Order: Atheriniformes}

44. Atlantic silversides Menidia menidia (Linnaeus, 1766). Marine, pelagic. Atlantic silversides are extremely abundant in the estuaries and shore regions of the inner Bay of Fundy and common along beaches in the outer Bay. In Minas Basin silversides form large schools over gravel and sand beaches in lower turbidity regions (Gilmurray and Daborn 1981). They feed largely on small copepods, neustonic prey like mysids and shrimp and floating or swimming insects and amphipods. They are a small species which live only one to two years and grow to about $20 \mathrm{~cm} \mathrm{~L}_{\mathrm{F}}$. Spawning is in May and June and juveniles settle in August (Gilmurray and Daborn 1981).

There is no commercial fishery for silversides in the Bay of Fundy, but they are an important forage fish for larger predators such as striped bass. Silversides occur along the beaches of Minas Basin and Passage (Dadswell et al. 1984a) but are seldom encountered offshore. They are probably at low risk from propeller tidal turbines.

\section{Order: Beloniiformes}

45. Atlantic saury Scomberesox saurus (Walbaum, 1792). Marine, pelagic. A rare visitor to the Bay of Fundy because of lower summer water temperatures (Scott and Scott 1988). Seldom seen or captured in Minas Basin. One was captured in a weir at Economy during July 2017 (Dadswell, pers. obs.).

\section{Order: Cyprinodontiformes}

46. Mummichog Fundulus heteroclitus (Linnaeus, 1766). Marine, benthic. Mummichog occur along shorelines of Minas Basin but are most abundant in tide pools $\left(28 \mathrm{~m}^{-2}\right.$, Bleakney and Bailey-Meyer 1979). They arrive in the tide pools during June and leave in October 
(Brown 1983). Mummichogs are another small prey species that are forage for larger predators especially blue herons. They seldom exceed $10 \mathrm{~cm} \mathrm{~L}_{\mathrm{T}}$ and age-4 (Brown 1983).

Mummichog should be expected in salt marsh tide pools along the shores of Minas Passage but are unlikely to be encountered in open water except near shore.

\section{Order: Gasterosteiformes 'sticklebacks'}

All sticklebacks are small fishes occurring in salt marsh, shoreline or pelagic habitats (Scott and Scott 1988). They are common to abundant in beach seine hauls (Dadswell et al. 1984a) and tide pools in Minas Basin (Bleakney and Bailey-Meyer 1979). They feed mostly on planktonic and neustonic prey (Imrie and Daborn 1981). None of the four species in Minas Basin exceed a maximum length of $10 \mathrm{~cm} \mathrm{~L}_{\mathrm{T}}$. None are fished commercially. All are prey for larger fishes. They are at little risk from propeller tidal turbines but could be impacted by development of tidal lagoon generation.

47. Fourspine stickleback Apeltes quadracus (Mitchill, 1815). Marine and estuarine, benthic. Fourspine stickleback are common throughout the Bay of Fundy along shorelines. They are abundant in lower salinities like the inner portions of Minas Basin (Dadswell et al. 1984a). If encountered in Minas Passage, they will occur along the shoreline or in tide pools.

48. Threespine stickleback Gasterosteus aculeatus Linnaeus, 1758. Marine and estuarine, benthic, pelagic. Threespine stickleback are the most common stickleback in the Bay of Fundy and are especially abundant along high salinity shorelines and among eel grass (Dadswell et al. 1984a). Unlike the other sticklebacks they often have completely pelagic populations that are found at the surface over deep water (Scott and Scott 1988).

Threespine sticklebacks will occur along the shoreline of Minas Basin and Minas Passage and there may be a small population pelagic over the deepest part of Minas Passage. The pelagic group may be present all year.

49. Blackspotted stickleback Gasterosteus wheatlandi Putnam, 1867. Marine, benthic. Blackspotted stickleback co-occurs with threespine stickleback along high salinity shorelines (Scott and Scott 1988). It is not pelagic. It is found along the shoreline and in tide pools of Minas Basin and the Passage during most of the year (Imrie and Daborn 1981). 
50. Ninespine stickleback Pungitius pungitius (Linnaeus, 1758). Marine, benthic. Ninespine stickleback co-occurs with threespine and blackspotted sticklebacks in lagoons along high salinity shores. It is also abundant in lower salinity tidal 'lakes' (Scott and Scott 1988). Specimens were commonly captured in seine hauls in Minas Basin (Dadswell et al. 1984a). It should be found along the shoreline of Minas Basin and Passage all year but will be rare except during cold water periods (Dadswell, pers. obs.).

\section{Order: Syngnathiformes 'pipefishes and sea horses'}

51. Northern pipefish Syngnathus fuscus Storer, 1839. Marine, pelagic. Pipefish are a warm water species found in lower salinity tidal 'lakes' around the Bay of Fundy (Scott and Scott 1988). It is especially abundant in localities with eelgrass. It is a small species, seldom exceeding $20 \mathrm{~cm} \mathrm{~L}$. There is no fishery.

Commonly captured in the Bramber weir (Dadswell et al. 2020) and in Cobequid Bay (Huntsman 1922) but probably uncommon in Minas Passage except along the shoreline and in lagoons. Juveniles are common in the surface drift among seaweed and eelgrass during August to October (Dadswell, pers. obs.).

\section{Order: Perciformes 'basses'}

52. White perch Morone americana (Gmelin, 1789). Estuarine and anadromous, benthic and pelagic. White perch are especially abundant in lower salinity regions of estuaries particularly those with tidal sills or barrages maintaining an upstream, lake-like situation (Annapolis, Peticodiac and Avon Rivers, Scott and Scott 1988, Daborn and Brylinsky 2004). It is rarely observed in Minas Basin and was only caught in low numbers among weir catches at Bramber (12 individuals, Dadswell et al. 2020). White perch will probably not be encountered in Minas Passage. White perch is taken by angling wherever common.

53. Striped bass Morone saxatilus (Walbaum, 1792). Anadromous, benthic and pelagic usually along marine shorelines. Striped Bass are abundant in the inner Bay of Fundy, especially Minas Basin (Broome 2016). Striped bass spawn at or near the head of tide in rivers during May-June. There is a large spawning concentration annually in the mouth of the Shubenacadie-Stewiacke River (Rulifson and Tull 1998, MacInnis 2012). Juveniles move into estuarine waters during their first summer and year-class success 
is dictated by warm, dry summers with an abundance of copepods in the nursery area (Duston et al. 2018). Growth is rapid and bass mature at age 3-5. They live to age 20-25 and reach $120 \mathrm{~cm} \mathrm{~L}_{\mathrm{T}}$ and $45 \mathrm{~kg}$ in weight (Rulifson and Dadswell 1995)

The population in the Shubenacadie-Stewiacke River has had successful recruitment since the early 1990's with an exceptional year class in 1999 (Bradford et al. 2015, Duston et al. 2018). Adult abundance was estimated at 18,000-27,000 fish (Fig 28, Douglas et al. 2003). There is a summer migration around the Bay of Fundy which consists of Canadian and US stocks (Rulifson and Dadswell 1995) and an unknown number of US fish enter Minas Basin each summer (Wirgin et al. 1995, Rulifson et al. 2008). Striped bass tagged in Minas Basin have been recaptured in Maine (1), Massachusetts (1), Rhode Island (1), Connecticut (2), New Jersey (2) and Virginia (1) (Rulifson et al. 2008, Bradford et al. 2015). On the other hand, tagging studies in Minas Basin indicate most of the Shubenacadie stock remains in the Basin during all stages of their life history. Of 1431 tags applied to bass at a weir on the north shore of Minas Basin 249 were recaptured in the Basin, but only 10 seawards of Minas Passage (Rulifson et al. 2008), and of 1126 tags applied on the south shore, 250 were recaptured in the Basin and only three seawards of the Passage (Broome 2016). In November there is an annual mass movement of bass upstream from Minas Basin into

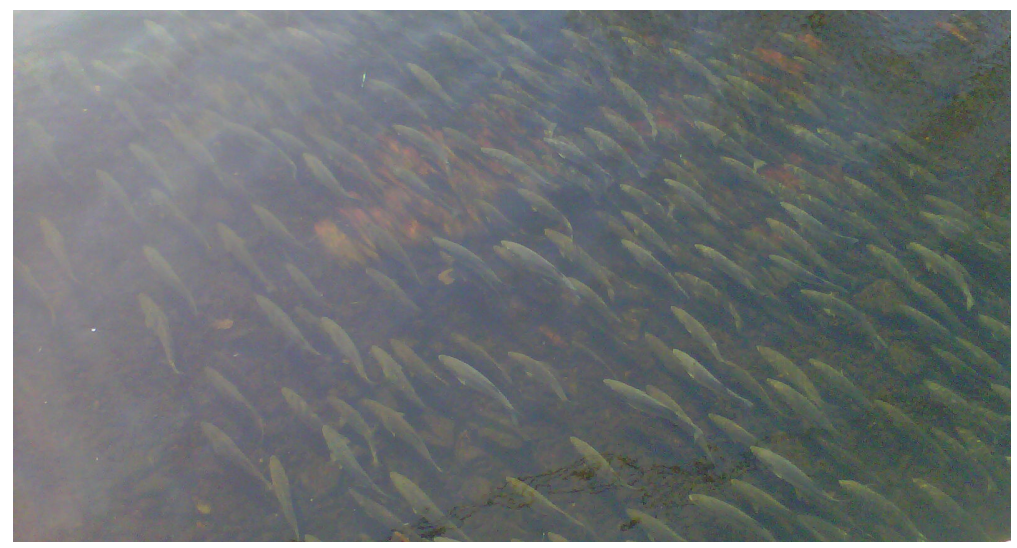

Fig 28 Striped bass school observed during the fall of 2014 under the railway bridge where the Shubenacadie River discharges from Shubenacadie Lake. The estimated size of the individual bass in the aggregation was 70-80 cm L $\mathrm{F}_{\mathrm{F}}$ (photograph courtesy G. Stephens, DFO). 


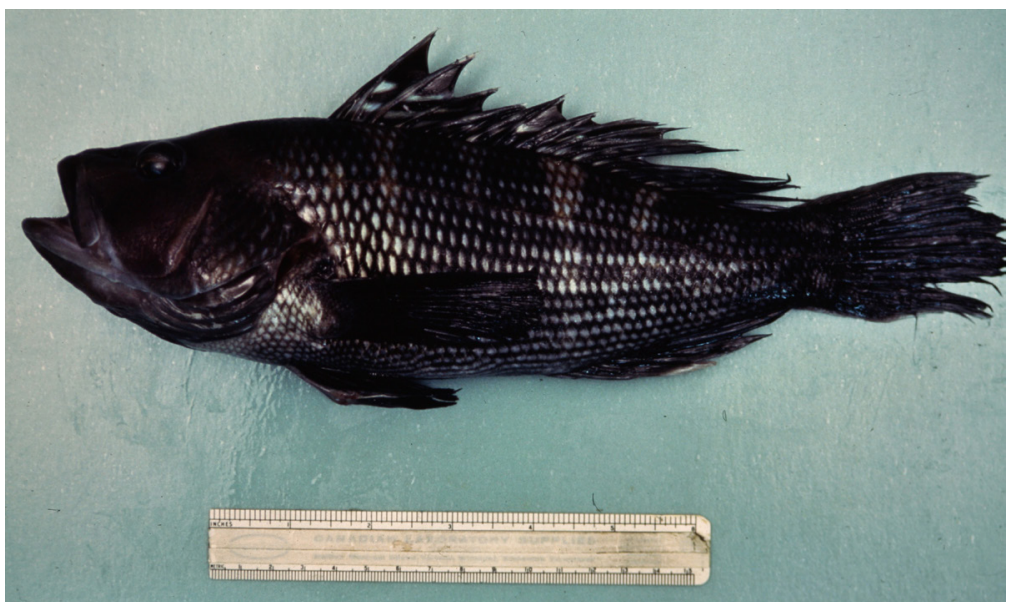

Fig 29 Black sea bass captured in an Economy weir during July, 2013 (photograph MJD).

Shubenacadie Grand Lake where they over winter (Fig 28, Bradford et al. 2015). An unknown portion of the Shubenacadie population also over winters in marine upwelling areas such as Minas Passage (Parramore and Rulifson 2001, Keyser et al. 2015) or at low salinity sites around the Bay of Fundy (Andrews et al. 2018).

Striped bass are captured in intertidal weirs and drift gill nets in Minas Basin and used to be taken by fixed gill nets around the shoreline (Dadswell et al. 1984). A total of 1,388 were captured by the Bramber weir during April-July 2017 (Dadswell et al. 2020). The commercial fishery for striped bass has been closed since 2003 but weir fishers are permitted a bycatch (one bass day ${ }^{-1}$ larger than $68.5 \mathrm{~cm} \mathrm{~L}_{\mathrm{T}}$ ). There is a large angling fishery in Minas Basin (Broome et al. 2009). During a short-term angler survey in Minas Basin in 2009, the catch was more than 1800 bass and catch rate was estimated at 2.2 bass.h $^{-1}$ (Duston 2010).

Striped bass adults are common in Minas Passage along the shoreline and have been detected with acoustic receivers in mid water at depths of 20-95 $\mathrm{m}$ in the Passage during all seasons (Broome 2016, Keyser et al. 2016). There will be an inward migration through Minas Passage during April to July and an outward migration during July to September with numerous long-term residents in the Passage during winter. Because of their large size and mid-water residence striped bass are at extreme risk from propeller tidal turbines. 
54. Black sea bass Centropristis striata (Linnaeus, 1758). Marine, benthic. One to a dozen specimens are taken regularly in the Linkletter weir at Economy, never in abundance, but commonly during most summers (Fig 29, W. Linkletter, commercial fisher, pers. comm.). Captured bass are usually 20-30 $\mathrm{cm} \mathrm{L}_{\mathrm{T}}$.

55. Bluefish Pomatomus saltatrix (Linnaeus, 1766). Marine, pelagic. Bluefish are a summer visitor to the inner Bay of Fundy during years of higher summer temperatures in the Bay of Fundy (Dadswell et al. 1984a). Bluefish are not known to reproduce in Canadian waters (Scott and Scott 1988). It can be abundant for short periods during July-August in some years and then may not be seen for 2-3 years. It is a schooling fish that preys on smaller schooling species (herring, menhaden, butterfish). Bluefish caught in Minas Basin are from 15-80 $\mathrm{cm} \mathrm{L}_{\mathrm{F}}$ (Fig 30).

Abundance of bluefish will be low to nonexistence in most years then common to abundant for a short period during July-August in Minas Basin and Passage. It is a pelagic species and generally found offshore. It is taken by drift gill nets, in weirs and by anglers when schools appear. Bluefish can be dangerous when brought onto a boat deck because they have large teeth and tend to bite (Scott and Scott 1988). Because bluefish are pelagic and relatively large it will be at risk from propeller tidal turbines.

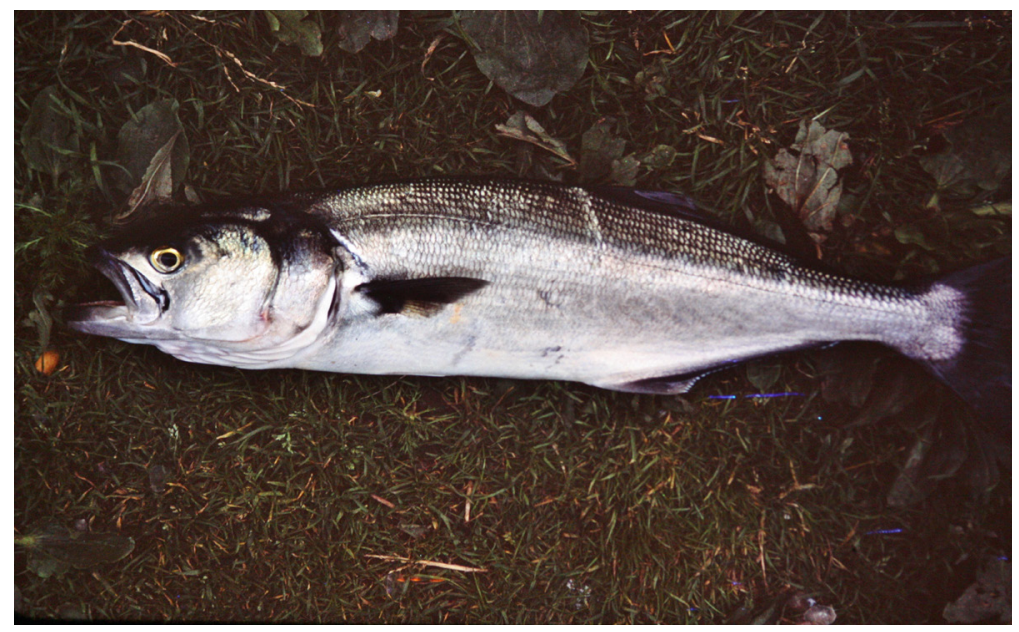

Fig 30 Adult bluefish captured by drift gillnet in Cobequid Bay during August, 1984 (photograph MJD). 
56. Weakfish Cynoscion regalis (Bloch and Schneider, 1801). Marine, benthic. Weakfish are a very rare occasional summer visitor to the inner Bay of Fundy (Dadswell and Rulifson 1994). One specimen was taken in a weir at Economy in 1955. A few will be encountered in Minas Basin and Passage on rare occasions.

57. Scup Stenotomus chrysops (Linnaeus, 1766). Marine, benthic. Occasional summer visitor to the inner Bay of Fundy. One specimen was captured in each of the Economy and Bramber weirs during 2013 (Fig 31). It is abundant along sandy shorelines south of Cape Cod.

58. Black drum Pogonias cromis (Linnaeus, 1766) Marine, benthic. Black drum are a rare, occasional summer visitor to the inner Bay of Fundy. A $1 \mathrm{~m}$ specimen was captured in a weir near Minas Passage in 1947 (Scott and Scott 1988).

59. Radiated shanny Ulvaria subbifurcata (Storer, 1839). Marine, benthic. Radiated shanny are common in the outer Bay of Fundy (MacDonald et al. 1984). It is especially abundant under rocks along cliff-like shores (Dadswell, pers. obs.) and may be common in Minas Passage along the shoreline. It is a small species and seldom exceeds $20 \mathrm{~cm} \mathrm{~L}_{\mathrm{T}}$ (Scott and Scott 1988). It will rarely be captured in any numbers except by directed searches during SCUBA sampling.

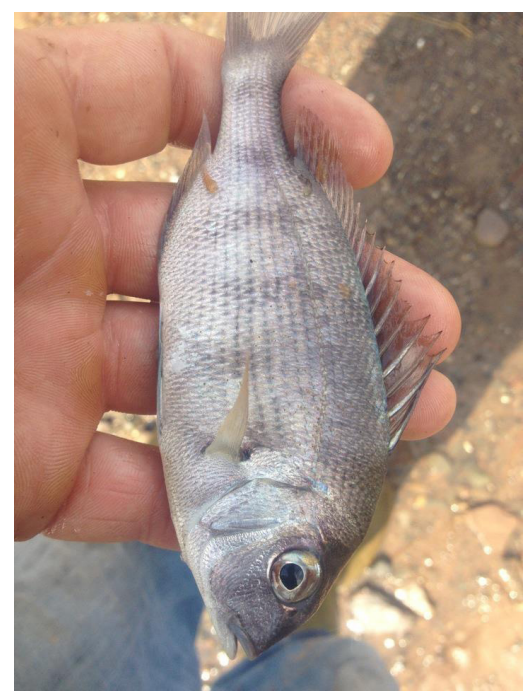

Fig 31 Scup captured in the Bramber weir during 2013 (photograph courtesy D. Porter, Avondale, NS). 
60. Rock gunnel Pholis gunnellus (Linnaeus, 1758). Marine, benthic and intertidal. Rock gunnels are a ubiquitous and abundant fish throughout the Bay of Fundy (Scott and Scott 1988). It can remain in the intertidal zone during low tide hiding under rocks and seaweed (Bleakney and McAllister 1973). Gunnels are a small fish rarely exceeding $20 \mathrm{~cm} \mathrm{~L}_{\mathrm{T}}$. It is probably common along the shoreline of Minas Passage but is seldom encountered in Minas Basin. During 2017 only five individuals were captured in the Bramber weir (Dadswell et al. 2020).

61. Atlantic wolffish Anarhichas lupus Linnaeus, 1758. Marine, benthic. Wolffish are common in deep, cold water regions of the Bay of Fundy (Scott 1987). They are usually found in areas with boulders and rough bottom with available den sites (Scott and Scott 1988). Wolffish have never been observed inside Minas Basin (Bleakney and McAllister 1973, Dadswell et al. 1984a) but may occur in Minas Passage. Wolffish feed on scallops and lobsters and can grow to a large size $\left(2.0 \mathrm{~m} \mathrm{~L}_{\mathrm{T}}\right)$. Most caught recently are under $1.0 \mathrm{~m} \mathrm{~L}_{\mathrm{T}}(\mathrm{Scott}$ and Scott 1988).

The wolffish fishery in the Bay of Fundy has never been large and there is no directed fishery. Most landings are from by catch in the scallop fishery. Landings averaged $61 t$ from 1998-2001 (Anon 2002).

Since there are scallop beds in Minas Passage wolfish will probably be found there, however, they would largely be confined to the bottom. They are likely to be present all year but would probably be most common in winter. Because of their benthic habitat they would be at low risk to propeller tidal turbines.

62. Ocean pout Zoarces americanus (Bloch and Schneider, 1801). Marine, benthic. Ocean pout are common to abundant in deep water of the outer Bay of Fundy and rare to common in the inner Bay (MacDonald et al. 1984, Scott 1987). Scott (1988) reported them from trawl catches in Minas Channel and Wehrell (2005) in trawl catches in Minas Basin. Bleakney and McAllister (1973) reported them stranded in the intertidal zone in Minas Basin. There is no commercial fishery for ocean pout (Scott and Scott 1988). Only one was captured in the Bramber weir during 2017 (Dadswell et al. 2020).

Ocean pout will occur in Minas Passage during summer but in low numbers. They are strictly benthic in habit and probably not at risk from propeller tidal turbines. 
63. Sand lance Ammodytes americanus DeKay, 1842. Marine, benthic and pelagic. Sand lance is abundant along sand and gravel beaches of the Bay of Fundy and over deep water, sand bottoms. The species forms dense schools over intertidal zones at high tide and then penetrates the substrate to remain in the intertidal zone during low tide (Scott and Scott 1988). They are a small species seldom exceeding $10 \mathrm{~cm} \mathrm{~L}_{\mathrm{T}}$ and a forage fish for many larger predators especially Atlantic sturgeon which vacuum sand lance from under the sand (McLean et al. 2013).

Sand lance are not common in Minas Basin although there is an abundance of sandy, benthic habitat but they may be locally abundant over sandy beaches. One was captured in the Bramber weir in 2017 (Dadswell et al. 2020). Their paucity in Minas Basin could be a factor of the warm summer temperatures. They may be more abundant in Minas Passage but there has been a lack of seine studies on beaches in that region (Dadswell et al. 1984a). Because of their small size and requirement for sand substrate they are at no risk from tidal propeller turbines in Minas Passage.

64. Atlantic mackerel Scomber scombrus Linnaeus, 1758. Marine, pelagic. Atlantic mackerel are common to abundant in the pelagic zone of the entire Bay of Fundy except in turbid regions like Cobequid Bay and Cumberland Basin (Dadswell et al. 1984a). Large weir catches were often made in Scots Bay (Leim 1924) but are rare inside Minas Basin (Dadswell et al. 2020). The only time mackerel were caught in the Bramber weir during 2017 was during neap tides when the water became clear.

Mackerel are highly migratory. They winter off Long Island then move north to the Bay of Fundy and the Gulf of St. Lawrence for the summer (Scott and Scott 1988). Mackerel appear in Minas Basin during May to August. They are caught in intertidal weirs and by drift gill nets. Because of low market demand the annual mackerel catch in the Bay of Fundy is not large even though mackerel are abundant. The allowable catch was set at 75,000 $t$ for several years but catches seldom exceed $20 \%$ of this value (CSAS 2005). The TAC is now reduced to $8000 t \mathrm{y}^{-1}$ (D. Themelis, DFO, pers comm.).

Mackerel will occur in Minas Basin and Passage during May to September and in some years may be abundant. They will be pelagic in the water column and in schools. Abundance could be in the 10's of thousands. Mackerel, because of their pelagic habitat, will be at moderate risk from propeller tidal turbines (Table 1). 


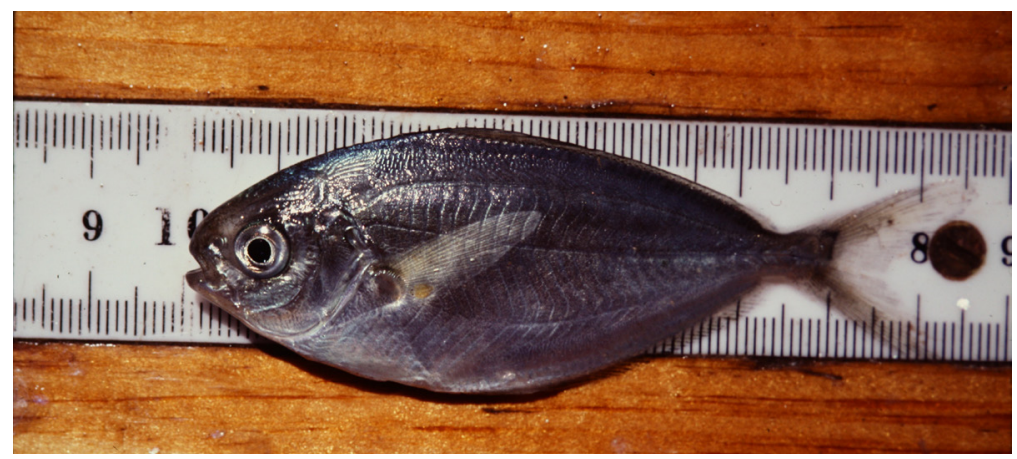

Fig 32 Butterfish captured in a drift gill net in Cobequid Bay during July, 1984 (photograph MJD).

65. Butterfish Peprilus triacanthus (Peck, 1804). Marine, pelagic. Butterfish are small forage fish (Fig 32, $<20 \mathrm{~cm} \mathrm{~L}_{\mathrm{T}}$ ). Large numbers are common in the inner Bay of Fundy during summer, especially in Minas Basin (Dadswell et al. 1984a). In most regions of the Atlantic coast there is a limited fishery for them but there is no directed fishery in Canada (Scott and Scott 1988).

Butterfish occur in Minas Basin from June to September and are a common catch in intertidal weirs (Dadswell et al. 1984a, Dadswell et al. 2020). During 2017, 536 were captured in the Bramber weir. They are common to abundant in Minas Passage and occupy the pelagic zone. Abundance could be in the millions, but accurate estimates are unavailable. Because of their small size they are at low risk from propeller tidal turbines.

\section{Order: Scorpaeniformes}

66. Striped searobin Prionotus evolans (Linnaeus, 1766). Marine, benthic. Searobins are rare in Canada occurring only in the Bay of Fundy region as strays from the Gulf of Maine (Scott and Scott 1988). One specimen was collected in a weir at Economy during the summer of 2013 and one at the Bramber weir in 2017.

67. Sea raven Hemitripterus americanus (Gmelin, 1789). Marine, benthic. Sea ravens are a common member of benthic fish community throughout the Bay of Fundy (MacDonald et al. 1984, Scott 1988). They are abundant in Minas Basin all year (Fig 33, Bleakney and McAllister 1973) and are taken by trawlers and in intertidal weirs (Dadswell et al. 1984a, Baker et al. 2014). During 2017 a total 


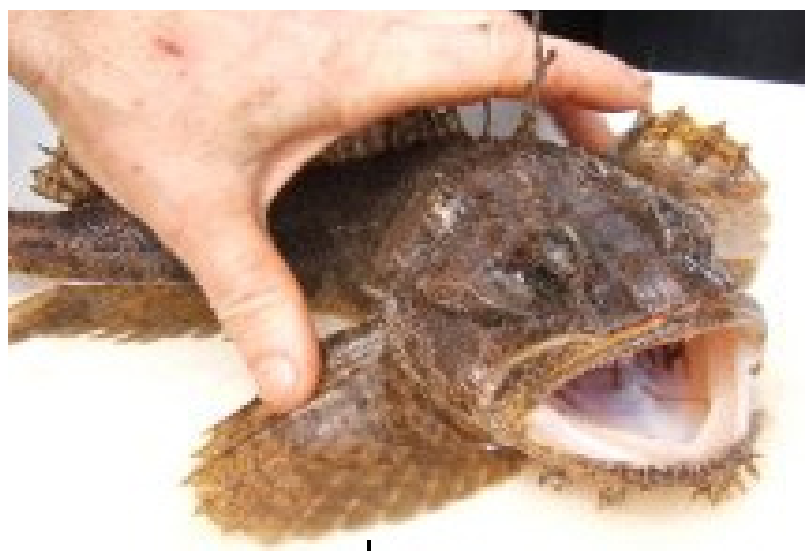

Fig 33 Juvenile sea raven found in a tide pool on the intertidal zone off Burntcoat Head during August, 2012 (photograph MJD).

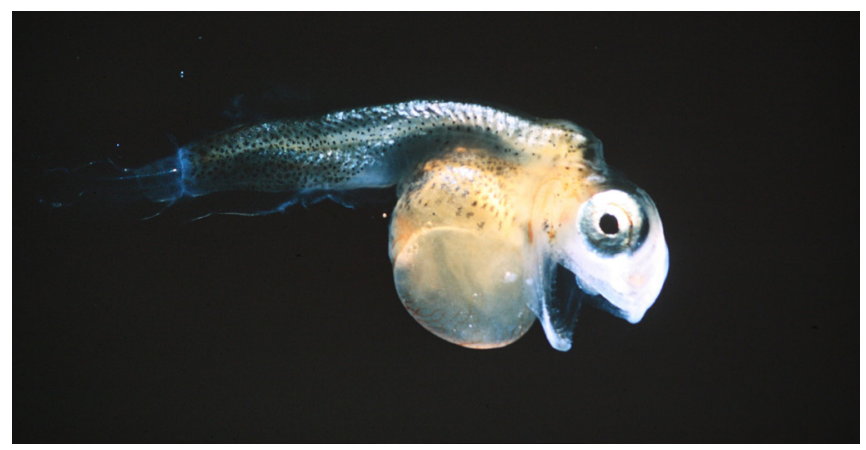

Fig 34 Larvae of sea raven hatched from eggs found under sponges along the lower intertidal zone of Cape Blomidon on January 4, 1974 (photograph courtesy of J.S. Bleakney).

of 643 were captured in the Bramber weir (Dadswell et al. 2020). There is no directed fishery for this species in Canada.

Sea ravens are probably found in Minas Passage during most of the year. Eggs and larvae are found in the lower intertidal zone along the Passage shore during winter in association with sponges (S. Bleakney, pers. comm.). The larvae are rather unique in having a very large mouth with teeth in the jaws (Fig 34, Fuiman 1977). Since their habitat is benthic they are at little risk from instream propeller tidal turbines. If lagoon tidal power is developed they may be impacted by the turbines. 
68. Grubby Myoxocephalus aenaeus (Mitchill, 1814). Marine, benthic. Grubby are a common, small, inshore species along hard substrate shorelines of the Bay of Fundy (Scott and Scott 1988). They are usually found in association with seaweed. Grubby seldom grow larger than $20 \mathrm{~cm} \mathrm{~L}_{\mathrm{T}}$. They are seldom seen or captured in Minas Basin probably because there is little hard substrate shoreline and seaweeds are rare because of winter ice scouring (Bleakney and McAllister 1973, Dadswell et al. 1984a).

Grubby may found along the shores of Minas Passage and could be common over hard substrates in deeper water. Because of their small size and benthic habitat, they are at little risk from propeller tidal turbines.

69. Longhorn sculpin Myoxocephalus octodecemspinosus (Mitchill, 1814). Marine, benthic. Longhorn sculpin are abundant in trawl catches from most parts of the Bay of Fundy (Scott 1988). They are a 'large' species of sculpin reaching about 35-45 $\mathrm{cm} \mathrm{L}_{\mathrm{T}}$ (Scott and Scott 1988). Longhorn sculpin are common during summer and winter in Minas Basin (Bleakney and McAllister 1973, Dadswell et al. 1984a). During 2017 a total of 705 were captured in the Bramber weir (Dadswell et al. 2020).

Longhorn sculpin are commonly captured off wharfs by recreational anglers. There is a small commercial fishery in the Bay of Fundy where they are used as lobster bait (H. Stone, DFO, pers. comm.). They are found year around in Minas Passage. Their benthic habitat should limit their interaction with propeller tidal turbines.

70. Shorthorn sculpin Myoxocephalus scorpius (Linnaeus, 1758). Marine, benthic. Shorthorn sculpin are common in most of the Bay of Fundy. This sculpin occurs onshore during winter and is mostly found over hard substrates (Scott and Scott 1988). They are not common inside Minas Basin (Dadswell et al. 1984a) but are taken occasionally in weir catches. Four were captured in the Bramber weir during 2017 (Dadswell et al. 2020).

Shorthorn sculpin should be common over the hard substrate bottom of Minas Passage and they will probably be present all year. This species was observed in a bottom video record taken around the FORCE tidal power test site during October 2009 (FORCE 2009). Like sea raven and longhorn sculpin they are little at risk from propeller tidal turbines. 


\section{Order: Labriformes 'wrasses'}

71. Tautog Tautoga onitis (Linnaeus, 1758). Marine, benthic, pelagic. Tautog are a rare summer visitor to the inner Bay of Fundy. One was captured by gill net in Cumberland Basin during 1979 (Dadswell et al. 1984a). Tautog will probably be seldom encountered in Minas Basin or Minas Passage.

72. Cunner Tautogolabrus adsperus (Walbaum, 1792). Marine, benthic, pelagic. The cunner is a common resident of the outer Bay of Fundy and is especially abundant around wharfs and rocky shores (Scott and Scott 1988). It is uncommon in the inner Bay of Fundy and inside Minas Basin (Bleakney and McAllister 1973). During 2017 a total of 51 individuals were captured in the Bramber weir (Dadswell et al. 2020). Cunner, however, should be expected in Minas Passage. The Passage has considerable hard bottom substrate and probably abundant underwater cavities. Cunner use cavities among the rocks during winter for hibernation (Scott and Scott 1988) and it may be common along the Minas Passage shore during this period. Since cunner are a small species and usually associated with a substrate they are unlikely to be at risk from propeller tidal turbines.

\section{Order: Cyclopteriformes 'lumpfishes'}

73. Lumpfish Cyclopterus lumpus Linnaeus, 1758. Marine, benthic and pelagic. Lumpfish are found throughout the Bay of Fundy Bay except in the turbid inner reaches and is known from Minas Basin (Bleakney and McAllister 1973, Wehrell 2005). It is most abundant along rocky shores and over hard, rocky bottom. All Cyclopteriformes have a ventral 'sucker' that allows them to attach to the substrate or seaweeds in order to maintain position in strong currents (Scott and Scott 1988). Lumpfish caviar is the basis for a commercial fishery in Newfoundland but there is no fishery in the Bay of Fundy (Dadswell et al. 1984a)

Juvenile lumpfish are very abundant in the surface floating masses of seaweed drifting in the Bay of Fundy and have been taken from this habitat in Minas Channel (Daborn and Gregory 1983). Adult, spawning males turn red in spring and remain to guard the egg mass attached to rocks after spawning. The habitat along the shores of Minas Passage is excellent for lumpfish spawning (Scott and Scott 1988, AECOM 2009). 
Lumpfish larvae and juveniles will be common in drifting masses of seaweed on the surface in Minas Passage during June to September. Abundance in some years could be high depending on survival of larvae (Daborn and Gregory 1983). Since they have been caught in Minas Channel and in Minas Basin (Scott 1988, Wehrell 2005), adult lumpfish may be abundant along the rocky shores of Minas Passage especially when spawning in spring. Because juveniles remain at the surface in drifting seaweed and adults are usually associated with hard benthic substrate, this species is unlikely to interact much with propeller tidal turbines and are at minimal risk.

74. Atlantic snailfish Liparus atlanticus (Jordan and Evermann, 1898). Marine, benthic. Atlantic snailfish are common in the Bay of Fundy in localities with kelp to which they attach with their ventral sucker (Scott and Scott 1988). They have been caught in Minas Passage by trawls that brought up kelp fronds (Dadswell et al. 1984a) and they have been reported from Minas Basin in tide pools during winter (Bleakney and McAllister 1973). Snailfish are small and rarely exceed $10 \mathrm{~cm} \mathrm{~L}_{\mathrm{T}}$ (Fig 35).

Atlantic snailfish should be common among kelp beds in Minas Passage year around. Their distribution will be concentrated along the shore and probably in depths less than $10 \mathrm{~m}$ which is about the

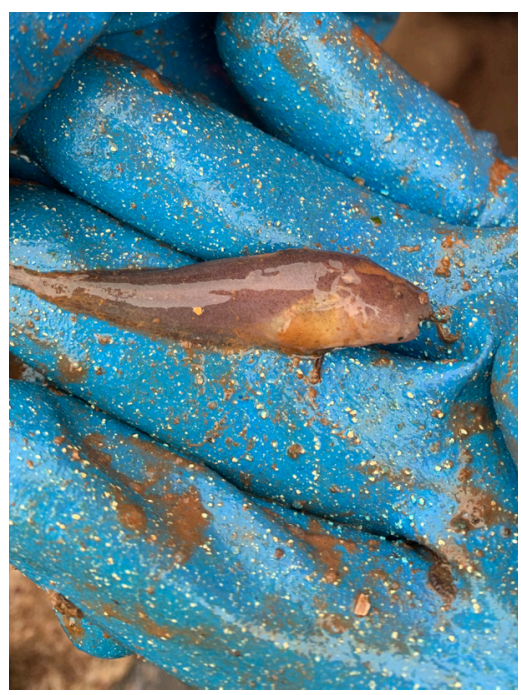

Fig 35 Atlantic snailfish captured in the Minas Basin during November, 2019 (photograph courtesy of E. Porter, Avondale, NS). 
deepest kelp distribution reaches in the $\mathrm{iBoF}$ (Dadswell, pers. obs.). They are at minimal risk from propeller tidal turbines.

75. Inquiline snailfish Liparus inquilinus Able, 1973. Marine, benthic. This small snailfish is usually found in association with sea scallops with whom they live commensally for their entire life (Able and Musick 1976). They are common wherever scallop beds occur such as along the Blomidon shore of Minas Basin and in Minas Channel (Dyer et al. 2005). They are a typical small snailfish seldom exceeding $72 \mathrm{~mm} \mathrm{~L}$. They are often striped with yellow bands (Bigelow and Schroeder 1953).

Inquiline snailfish should be common year around in Minas Passage wherever there are sea scallops. Snailfish larvae will probably be common near the surface in Minas Passage during late winter and spring.

76. Gulf snailfish Liparus coheni Able, 1976. Marine, benthic. This small snailfish is usually found in association with kelp. Abundant in shallow depths along the shores of Minas Passage (Dadswell et al. 1984a).

\section{Order: Pleuronectiformes 'flounders'}

77. Summer flounder Paralichthys dentatus (Linnaeus, 1766). Marine, benthic. Summer flounder is a rare summer visitor to the Bay of Fundy (Scott and Scott 1988). Two were captured in the Bramber weir during 2017 (Dadswell et al. 2020).

78. American fourspot flounder Hippoglossina oblonga (Mitchill, 1815). Marine, benthic. Fourspot flounder is a southern species that is an occasional summer visitor to the inner Bay of Fundy but is never abundant (Scott and Scott 1988). It has been captured in Cumberland Basin and Minas Basin (Dadswell and Rulifson 1994). It will probably occur rarely in Minas Passage and in small numbers. It is a benthic species and likely remains on bottom at all times making it at little risk to tidal turbines.

79. Windowpane Scophthalmus aquosus (Mitchill, 1815). Marine, benthic. Windowpane is common throughout the Bay of Fundy especially over sandy substrate (Scott 1987). They are very abundant in Minas Basin and often the most abundant fish in intertidal weir catches (Leim and Bousfield 1959, Baker et al. 2014). During 2017 a total of 18,860 were taken in the Bramber weir (Dadswell et al. 2020). They are seldom fished commercially in Canada but are taken for lobster bait in Minas Basin weirs (Scott and Scott 1988). 
Windowpane is probably uncommon in Minas Passage because of the low incidence of sandy substrate (AECOM 2009). It could, however, be locally abundant along shore lines where there are sandy beaches since it is common in Minas Channel (Scott 1988) and was abundant in Minas Basin trawl catches (Wehrell 2005). Similar to other smaller flatfish species it is probably at little risk from propeller turbines because of its benthic nature.

80. Witch flounder Glyptocephalus cynoglossus (Linnaeus, 1758). Marine, benthic. Witch flounder is a common resident of deep water, mud bottom locations in the Bay of Fundy (MacDonald et al. 1984, Scott 1987). It is an important commercial flounder and is marketed in Canada as sole.

Witch have never been captured in Minas Basin and are rare in the inner Bay of Fundy (Scott 1988). They may occur in Minas Channel and/or Minas Passage.

81. Atlantic halibut Hippoglossus hippoglossus (Linnaeus, 1758). Marine, benthic. Halibut are found throughout Bay of Fundy (Scott 1988) but only juveniles penetrate into Minas Basin during spring and early summer (M. Brylinsky, pers. comm., Wehrell 2005). Only two juvenile halibut were observed in the Bramber weir during 2017 (Dadswell et al. 2020), but 15 were observed during June and July by the 2004 trawl survey (Wehrell 2005).

Halibut are the largest flatfish and $200 \mathrm{~cm} \mathrm{~L}_{\mathrm{T}}$ fish are taken in the commercial fishery (Scott and Scott 1988). Large adults are common around the Advocate region of the inner Bay of Fundy and support a small commercial fishery (Simon and Comeau 1994). Juveniles and adults are taken by hand lines and bottom set long lines. Annual landings in the inner Bay of Fundy are about $10 t$ (Dyer et al. 2005).

Halibut are a predatory flatfish and large individuals eat fish exclusively (Scott and Scott 1988). They are known to pursue herring schools (Bigelow and Schroeder 1953). Large and small individuals should be expected in Minas Passage during spring. They will occur throughout the water column during bouts of foraging. Juvenile individuals probably follow herring schools into Minas Basin from March to June before warm water temperatures restrict halibut occurrence inside the Basin (Wehrell 2005). Abundance in Minas Passage is probably in the range of a few hundred to a few thousand individuals annually. Because of their pelagic behavior and large size adults are at extreme risk from propeller tidal turbines (Table 1). 
82. American smooth flounder Pleuronectes putnami (Gill, 1864). Estaurine, benthic. Smooth flounder are found in inshore, warm water habitats throughout the Bay of Fundy (Scott and Scott 1988). They are most abundant in the iBoF (Minas and Cumberland Basins) but also common in Passamaquoddy and St. Mary's Bay. In Minas Basin smooth flounder feed over mud flats at high tide. In these sites a few thousand individuals can occur daily (Scully 1983).

They are a common catch in intertidal weirs. During 2017 a total of 5,841 individuals were captured in the Bramber weir (Dadswell et al. 2020). They are not usually utilized as a commercial species in Canada (Scott and Scott 1988) but some are taken for lobster bait from weir catches in Minas Basin (Dadswell, pers. obs.). Smooth flounder are probably not common in Minas Passage except in localized, inshore mud habitats.

83. Winter flounder Pseudopleuronectes americanus (Walbaum, 1792). Marine, benthic. Winter flounder are the most abundant and ubiquitous flounder in the Bay of Fundy. They are a dominant resident of most benthic fish communities in both the inner and outer Bay of Fundy (MacDonald et al. 1984, Scott 1987). Winter flounder spawn inshore in May. Juveniles are common along shorelines in fall (Dadswell et al. 1984a). Growth is rapid and they reach maturity at age-3 (Scott and Scott 1988).

Winter flounder migrate in and out of the Bay of Fundy between spring and fall (MacDonald et al. 1984). Their abundance peaks in Minas Basin during July then declines during summer both from the effects of migration and the intense fishery (Wehrell 2005). They leave the Basin by October. Flounder spawn in Minas Basin during April-May and juveniles settle in the shallows during August. Minas Basin represents one of the most valuable nursery areas for winter flounder in the Bay of Fundy (Scott and Scott 1988).

Winter flounder support important commercial and recreational fisheries in the Bay of Fundy (Simon and Comeau 1994). They are captured commercially by trawls and intertidal weirs in Minas Basin. During April-July 2017, an estimated 24,200 were taken in the Bramber weir (Dadswell et al. 2020). They are also taken in large numbers by drags in Scots Bay and Minas Channel (Wehrell 2005). Flounder landings in the region peaked at $200 t$ in 1992-93 but declined to $100 t$ by 2006 (Dyer et al. 2005). 
Winter flounder will be migrating inward through Minas Passage from April to June and outward from July to October. There has never been a population estimate for the stock in Minas Basin during summer. But since the annual landings in the recent past were approximately $100 t$ (Dyer et al. 2005), the average weight of flounder in the Minas Basin catch is approximately 500 gm (Wehrell 2005) and annual exploitation rate $(\mu)$ probably in the order of 0.25 (DFO 2017b); a minimum adult stock size can be estimated at about 800,000 fish. All these adult flounder as well as juveniles pass through Minas Passage twice annually. But since they are a benthic species, winter flounder are probably not at risk from propeller tidal turbines.

84. Yellowtail flounder Limanda ferruginea (Storer, 1839). Marine, benthic. Yellowtail flounder are taken consistently in the outer and inner Bay of Fundy in association with winter flounder but they are never abundant (MacDonald et al. 1984, Scott 1987). Wehrell (2005) observed three yellowtails taken in Minas Basin during a summer-long trawl survey when thousands of winter flounder were taken daily.

A few yellowtail flounder may occur in Minas Basin and Passage annually during summer. Since they are strictly benthic in habitat. they are at little risk from propeller tidal turbines.

\section{Order: Tetraodontiformes "filefishes"}

85. Ocean sunfish Mola mola (Linnaeus, 1758). Marine, pelagic. Ocean sunfish are a common but never abundant summer visitor to the Bay of Fundy (Scott and Scott 1988). Large specimens have been captured in weirs of the outer and inner Bay during summer, but seldom more than one or two individuals. Parasites from an individual caught in a Scots Bay weir are stored in the Acadia University museum.

Ocean sunfish feed on jellyfish and attain a large size (2-3.3 $\mathrm{m} \mathrm{L}_{\mathrm{T}}$; Scott and Scott 1988). They have a habit of 'basking' on the ocean surface laying on their side. A single, large individual was observed 'basking' on the surface near Blomidon in Minas Basin during late June 2017 (G. Travis, commercial fisher, pers. comm.). There is no fishery for ocean sunfish.

Ocean sunfish will probably occur in Minas Basin and Passage during most summers but abundance will rarely exceed 1-2 individuals. Because they have a large body size, ocean sunfish will be at 
risk from propeller turbine strikes. Since they spend a considerable time on or near the surface and abundance is low in the iBoF, their overall risk to turbines is probably low.

\section{CONCLUSIONS}

The fish community in Minas Basin can be characterized into four assemblages. There is an assemblage of mainly smaller fish species that live, reproduce in and occupy Minas Basin year around. This grouping consists of tomcod, rainbow smelt, Atlantic silversides, smooth flounder, windowpane flounder, mummichog, skates, striped bass, seasnails, sculpins and sticklebacks. A second assemblage consists of summer migrants into Minas Basin including marine species and diadromous fishes that reproduce in or utilize the local streams for growth. This group consists of sea lamprey, porbeagle, great white shark, spiny dogfish shark, Atlantic sturgeon, American eel, Atlantic herring, American shad, blueback herring, alewife, Atlantic salmon, silver hake, Atlantic mackerel, butterfish, monkfish and winter flounder. They are the dominant community that supports the commercial fishery. A cold-water assemblage enters the Basin in early spring and possibly in fall and winter and departs when water temperatures surpass about $10 \mathrm{C}^{\circ}$. Atlantic cod, pollock, white hake, ocean pout and halibut are some representatives. Rare cold-water and/or offshore species among this grouping are spotted hake and longfin hake. The final assemblage consists of warm-water migrants that arrive from the south when Basin water temperatures reach their annual maximum. Some members of this group are basking shark, sand tiger shark, bluefish, black sea bass, scup, fourspot flounder, tautog and striped searobin.

Minas Basin is a northern terminus for coastal migrant fishes migrating along the North American Atlantic coast in summer (Dadswell et al. 1987, Moore 1998, Rulifson et al. 2008, Dadswell et al. 2016). A large portion of the coastal migrant fish stocks pass through the inner Bay of Fundy each year including spiny dogfish shark, Atlantic sturgeon, American shad, alewife, blueback herring, winter flounder and striped bass. Tagging and DNA discrimination studies demonstrate that these species represent populations from as far south as Florida, North Carolina, Virginia, New York and Massachusetts (Wirgin et al. 2012). 
The diversity and abundance of the Minas Basin-Minas Passage fish community will be impacted to greater or lesser degree by the development of tidal power in this region with the largest tides in the world. Fishes that could be impacted severely by propeller tidal turbines deployed in Minas Passage are: endangered great white shark and endangered iBoF Atlantic salmon and other commercially or recreationally important species including Atlantic sturgeon, American shad, Atlantic herring, alewife, blueback herring, halibut and striped bass (Table 1).

Tidal power development in Minas Passage using instream propeller turbines would impact both Minas Basin and distant commercial and recreational fisheries. The Minas Basin weir fishery catches would probably decline in response to turbine mortality of Atlantic herring, alewife, blueback herring and American shad. The recreational fishery for striped bass in Minas Basin would be impacted especially from the loss of large adults over wintering in Minas Passage. Distant commercial fisheries that would be affected by declines in abundance are the Atlantic sturgeon fishery in the Saint John River, NB and the American shad fishery on the east coast of the US. Repeated movement of sturgeon through Minas Passage annually over a long period of their life span (20-30 years) means they are at extreme risk (Dadswell et al. 2016, Stokesbury et al. 2016, Taylor et al. 2016).

Acknowledgements We thank the fishers of Minas Basin for their help and the faithful recording of fish occurrences over a period of almost 50 years: Gerald and Anthony Lewis of Five Islands, Wayne and Vicki Linkletter of Economy, Darren and Erica Porter of Avondale and Glanville and Charles Travis of Canning, Nova Scotia. We are indebted to a large contingent of researchers and graduate students from Acadia and East Carolina Universities that dedicated themselves to elucidating the biology of the fishes in the inner Bay of Fundy. They include M. Brylinsky, P. Crawford, G. Melvin, P. Williams, D. Themelis, H. Stone, S. McKenna, D. Imrie, M. Gilmurray, B. Scully, T. Moore, W. Hogans, K. Tull, L. Parramore, S. Wehrell, A. Spares, M. McLean, G. Nau, L. Logan-Chesney, J. Broome, F. Keyser, G. Baker, D. Quinn and J. Widden. Graham Daborn, Anna Redden, Trevor Avery and Michael Stokesbury provided student research funding and laboratory facilities. Daphne Themelis and Heath Stone kindly critiqued the manuscript. 


\section{REFERENCES}

Able, K.W. \& Musick, J.A. (1976). Life history, ecology and behavior of Liparis inquilinus (Pisces: Cyclopteridae) associated with the sea scallop, Placopecten magellanicus. Fisheries Bulletin 74: 409-421.

AECOM. (2009). Environmental assessment registration document - Fundy tidal energy demonstration project. Volume 1: environmental assessment. Fundy Ocean Research Centre for Energy Pro. \# 107405.

Amiro, P.G. (2003). Population status of inner Bay of Fundy Atlantic salmon (Salmo salar) to 1999. Canadian Fisheries and Aquatic Sciences Technical Report 2488.

Amiro, P.G., Gibson, J. \& Drinkwater, K. (2003). Identification and exploration of some methods for designation of critical habitat for survival and recovery of inner Bay of Fundy Atlantic salmon (Salmo salar). Canadian Scientific Advisory Secretariat (CSAS) WP. 2003/120.

Amos, C.L. (1984). An overview of sedimentological research in the Bay of Fundy. Canadian Technical Report of Fisheries and Aquatic Sciences 1256: 31-44.

Andrews, S.N., Wallace, B., Gautreau, M., Linnansaari, T. \& Curry, R.A. (2018). Seasonal movements of striped bass Morone saxatilis in a large tidal and hydropower regulated river. Environmental Biology and Fisheries 101: 1549-1558.

Anon. (1986). The one that didn't get away. The Advertiser, Kentville, NS. July 15, 1986: 1 .

Anon. (2006). Eastern Georges Bank haddock. Transboundary Research Assessment Committee Status Report 2006/02.

Baker, M., Reed, M. \& Redden, A.M. (2014). Temporal patterns in Minas Basin in intertidal weir catches and presence of harbour porpoise during April-August 2013. Acadia Centre for Estuarine Research Technical Report 120.

Beanlands, D.R., Branton, R. \& Mohn, R. (2000). Status of monkfish in 4VWX5Zc. Canadian Scientific Advisory Secretariat, Research Document 2000/143.

Big Moon Power Canada. (2018). www.Bigmoonpower.com

Bigelow, H.B. \& Schroeder, W.C. (1953). Fishes of the Gulf of Maine. Fisheries Bulletin of the Fish and Wildlife Service 53. US Government Printing Office, Washington, D, USA.

Bleakney, J.S. \& Bailey-Meyer, K. (1979). Observations on salt-marsh tide pools, Minas Basin, NS. Proceedings of the Nova Scotian Institute of Science 29: 353-371.

Bleakney, J.S. \& McAllister, D.E. (1973). Fishes stranded during low tides in Minas Basin, NS. Canadian Field-Naturalist 87: 371-376.

Bousfield, E.L. \& Leim, A.H. (1959). The fauna of Minas Basin and Minas Channel. National Museum of Canada, Bulletin 166: 1-30.

Bradford, R.G. (1987). The biology and ecology of the Minas Basin spring-spawning herring. M.Sc. Thesis, University of New Brunswick, Fredericton, NB. 
Bradford, R.G. \& Iles, T.D. (1992). Unique biological characteristics of spring-spawning herring (Clupea harengus L.) in Minas Basin, NS, a tidally dynamic environment. Canadian Journal of Zoology 70: 641-648.

Bradford, R.G. \& Iles, T. D. (1993). Retention of herring Clupea harengus larvae inside Minas Basin, inner Bay of Fundy. Canadian Journal of Zoology 71: 56-63.

Bradford, R.G., Halfyard, E.A., Hayman, T. \& LeBlanc, P. (2015). Overview of 2013 Bay of Fundy striped bass biology and general status. Canadian Scientific Advisory Secretariat, Research Document 2015/024.

Broome, J.E. (2014). Population characteristics of striped bass (Morone saxatilis Walbaum, 1792) in Minas Basin and patterns of acoustically detected movements within Minas Passage. M.Sc. Thesis, Acadia University, Wolfville, NS.

Broome, J.E., Redden, A.M., Dadswell, M.J., Vaudry, K. \& Stewart, D. (2009). Population characteristics, movement and angling of the striped bass (Morone saxatilis) summer aggregation in Minas Basin, NS. In. Resource development and its implications in the Bay of Fundy and Gulf of Maine. (eds) Redden, A.M., Percy, J.A., Wells, P.G. and Rolston, S.J. Proceedings $8^{\text {th }}$ BoFEP Fundy Science Workshop Technical Report 4: 203-213.

Brown, J.F.S. (1983). The ecology of Fundulus heteroclitus at Kingsport salt marsh, Minas Basin, NS. M.Sc. Thesis, Acadia University, Wolfville, NS.

Bucklund, H.C., Masters, I., Orme, J.A. \& Backer, T. (2013). Cavitation inception and stimulation in blade element momentum theory for modelling tidal stream turbines. Proceedings of the Institution of Mechanical Engineers: Journal of Power and Energy, Part A. Journal of Power and Energy 227: 479-485.

Bundy, A. \& Fannin, L.P. (2005). Can Atlantic cod (Gadus morhua) recover? Exploring trophic explanations for the non-recovery of the cod stock on the eastern Scotian Shelf. Canadian Journal of Fisheries and Aquatic Science 62: 1474-1489.

Cammen, L.M. (1984). Microbial ecology of the Bay of Fundy. Canadian Fisheries and Aquatic Sciences Technical Report 1256: 115-134.

Campana, S.E. (2007). Shark fisheries. Canadian Shark Research Laboratory. www.marinebiodiversity.ca/shark.

Campana, S.E., Gibson, A.J.F., Marks, L., Joyce, W., Rulifson, R.A. \& Dadswell, M.J. (2008). Stock structure, life history, fishery and abundance for spiny dogfish (Squalus acanthias) in Atlantic Canada. Canadian Scientific Advisory Secretariat, Research Document 2007/2008.

Campana, S.E., Joyce, W., Marks, L., Natanson, L., Kohler, N.E., Jensen, J.F., Mello, J.L., Pratt, H.L. Jr. \& Myklevoll, S. (2002). Population dynamics of the porbeagle in the Northwest Atlantic Ocean. Journal of Fisheries Management 22: 106-121.

Cape Sharp Tidal. (2018). Cape Sharp Tidal scores Bay of Fundy touchdown. www.marineenergy.biz/2018/07/24/cape-sharp-tidal. 
Carey, F.G., Kanwisher, J.W., Brazier, O., Gabrielson, G., Casey, J.G. \& Pratt, H.L. Jr. (1982) Temperature and activities of a white shark, Carcharodon carcharias. Copeia 2: 254-260.

Case, G.R. (1968). Inland shark occurrence. Underwater Naturalist 5: 20-21, 37.

Casey, J.G. \& Kohler, N.E. (1990). Long distance movements of Atlantic sharks from the NMFS Cooperative shark tagging program. Pp 87-90. In: Discovering sharks.

Clark, D.S. \& Emberley, J. (2009). Assessment of cod in Division 4X in 2008. Canadian Scientific Advisory Secretariat, Research Document $2009 / 018$.

Cornett, A., Cousineau, J. \& Nistor, I. (2013). Assessment of hydrodynamic impacts from tidal power lagoons in the Bay of Fundy. International Journal of Marine Energy 1: 33-54.

COSEWIC (Committee on the Status of Endangered Wildlife in Canada). (2010). COSEWIC assessment and status report on barndoor skate Dipturus leavis in Canada. Committee on the Status of Endangered Wildlife in Canada, Ottawa, Ont.

COSEWIC. (2012). COSEWIC assessment and status report on the American eel Anguilla rostrata in Canada. Committee on the Status of Endangered Wildlife in Canada, Ottawa, Ont.

COSEWIC. (2014). COSEWIC assessment and status report on the Porbeagle Lamnus nasus in Canada. Committee on the Status of Endangered Wildlife in Canada, Ottawa, Ont.

CSAS. (Canadian Science Advisory Secretariat. (2005). Atlantic mackerel of the Northwest Atlantic in 2004. Canadian Scientific Advisory Secretariat, Scientific Advisory Report 2005/014.

CSAS. (2006). Cod on the Scotian Shelf and in the Bay of Fundy (Div. 4X/5Y). Canadian Scientific Advisory Secretariat, Scientific Advisory Report 2006/046.

CSAS. (2007). 2007 assessment of 4VWX herring. Canadian Scientific Advisory Secretariat, Scientific Advisory Report 2007/023.

CTV News (2018). Great white shark snatches striped bass from fisherman. https://atlantic.ctvnews.ca/great white shark.

Daborn, G.R. (1984). Zooplankton studies in the upper Bay of Fundy since 1976. Canadian Technical Report of Fisheries and Aquatic Sciences 1256: $135-161$.

Daborn, G.R. \& Brylinsky, M. (2004). Fish population studies of the Avon estuary, Pesaquid Lake and the lower Avon River, 2003. Acadia Centre for Estuarine Research Technical Report 76.

Daborn, G.R. \& Gregory, R.S. (1983). Occurrence, distribution and feeding habits of juvenile lumpfish, Cyclopterus lumpus L. in the Bay of Fundy. Canadian Journal of Zoology 61: 797-801.

Dadswell, M.J. (1979). Biology and population characteristics of the shortnose sturgeon, Acipenser brevirostrum LeSueur, 1818 (Osteichthyes: Acipenseridae), in the Saint John River estuary, NB, Canada. Canadian Journal of Zoology 57: 2186-2210. 
Dadswell, M.J. (1979). The Canso Causeway and its possible effects on the regional inshore fisheries - an overview. In. Canso Environmental Workshop. Ed. McCracken, F.D. Department of Fisheries and Environment, Fisheries and Marine Service Technical Report 834 (Part 1): 1-13.

Dadswell, M.J. (1985). Status of blueback herring, Alosa aestivalis, in Canada. Canadian Field-Naturalist 99: 409-412.

Dadswell, M.J. (1997). Stock structure of American shad, Alosa sapidissima, in the Gulf of Maine and the Bay of Fundy. Canadian Atlantic Fisheries, Scientific Advisory Committee, Research Document 86/97.

Dadswell, M.J. (2006). A review of the status of Atlantic sturgeon, Acipenser oxyrinchus Mitchill, 1814, in Canada, with comparisons to Europe and the United States. Fisheries 31: 218-229.

Dadswell, M.J., Bradford, R, Leim, A.H., Scarratt, D.J., Melvin, G.D. \& Appy, R.G. (1984a). A review of research on fishes and fisheries in the Bay of Fundy between 1976 and 1983 with particular attention to its upper reaches. Canadian Fisheries and Aquatic Sciences Technical Report 1256: 163-294.

Dadswell, M.J., Ceapa, C., Spares, A.D., Stewart, N.D., Curry, R.A., Bradford, R.D. \& Stokesbury, M.J.W. (2017). Population characteristics of adult Atlantic sturgeon captured by the commercial fishery in the Saint John River estuary, NB, Canada. Transactions of the American Fisheries Society 146: 318-330.

Dadswell, M.J., Melvin, G.D. \& Williams, P.J. (1983). Effects of turbidity on the temporal and spatial utilization of the inner Bay of Fundy by American shad Alsoa sapidissima (Pisces: Clupeidae) and its relationship to the local fisheries. Canadian Journal of Fisheries and Aquatic Science 40 (Supp. 1): 322-330.

Dadswell, M.J., Melvin, G.D., Williams, P.J. \& Brown, G.S. (1984b). Possible impact of large-scale tidal power developments in the upper Bay of Fundy on certain migratory fish stocks of the Northwest Atlantic. Canadian Fisheries and Aquatic Sciences Technical Report 1256: 577-599.

Dadswell, M.J., Melvin, G.D.,Williams, P.J. \& Themelis, D.E. (1987). Influence of origin, life history and chance on the Atlantic coast migration of American shad. American Fisheries Society Symposium 1: 313-330.

Dadswell, M.J. Nau, G. \& Stokesbury, M.J.W. (2013). The first verified record for a shortnose sturgeon Acipenser brevirostrum LeSueur, 1818 in Minas Basin, Bay of Fundy, NS Canada. Proceedings of the Nova Scotian Institute of Science 47: 273-279.

Dadswell, M.J. \& Rulifson, R.A. (1994). Macrotidal estuaries: a region of collision between migratory marine animals and tidal power development. Biological Journal of the Linnean Society 51: 93-113.

Dadswell, M.J., Rulifson, R.A. \& Daborn, G.R. (1986). Potential impact of large-scale tidal power developments in the upper Bay of Fundy on fisheries resources of the Northwest Atlantic. Fisheries 11: 26-35. 
Dadswell, M.J., Spares, A.D., McLean, M.T., Harris, P. \& Rulifson, R.A. (2018). Long term effect of a tidal, hydroelectric turbine on the populations of three anadromous fish species. Journal of Fish Biology 93: 192-206.

Dadswell, M.J., Spares, A.D., Porter, E., \& Porter, D. (2020). Diversity, abundance and size structure of fishes and invertebrates captured by intertidal fish weir at Bramber, Minas Basin, NS. Proceedings of the Nova Scotian Institute of Science 50: 283-318.

Dadswell, M.J., Spares, A.D., Reader, J.M. \& Stokesbury, M.J.W. (2010). The North Atlantic subpolar gyre and the marine migration of Atlantic salmon Salmo salar: the merry-go-round hypothesis. Journal of Fisheries Biology 77: 435-467.

Dadswell, M.J., Wehrell, S.H., Spares, A.D., McLean, M.T., Beardsall, J.W., Logan-Chesney, L.M., Nau, G.S., Redden, A.M. \& Stokesbury, M.J.W. (2016). The annual feeding aggregation of Atlantic sturgeon Acipenser oxyrinchus in the inner Bay of Fundy: population characteristics and movements. Journal of Fisheries Biology 89: 2107-2132.

Deng, Z., Guensch, G.R., McKinstry, C.A., Mueller, R.P., Dauble, D.D. \& Richmond, NS. (2005). Evaluation of fish injury mechanisms during exposure to turbulent shear flow. Canadian Journal of Fisheries and Aquatic Science 62: 1513-1522.

Desplanque, F.B. \& Mossman, D.J. (1998). A review of ice and tide observations in the Bay of Fundy. Atlantic Geology 34: 195-209.

DFO. Department of Fisheries \& Oceans Canada. (1997). Gaspereau, Maritimes Region Overview. DFO Science Stock Status Report D3-17.

DFO. (2017a). Assessment of 4X5Y haddock, 2016. Canadian Scientific Advisory Secretariat, Scientific Advisory Report, 2017/006.

DFO. (2017b). Stock assessment of Winter Flounder (Pseudopleuronectes americanus) of the southern Gulf of St. Lawrence (NAFO Div. 4T) to 2018. Canadian Scientific Advisory Secretariat, Scientific Advisory Document 2017/022.

Douglas, S.G., Bradford, R.G. \& Chaput, G. (2003). Assessment of striped bass (Morone saxatilis) in the Maritime provinces in the context of species at risk. Canadian Scientific Advisory Secretariat, Research Document 2003/008.

Durbin, A.G. \& Durbin, E.G. (1975). Grazing rates of the Atlantic menhaden Brevoortia tyrannus as a function of particle size and concentration. Marine Biology 333: 265-275.

Duston, J. (2010). Bay of Fundy striped bass recreational angler survey, 2009. Department of Plant and Animal Sciences, Nova Scotia Agricultural College.

Duston, J., Mauriquez-Hernanadez, J., Macinnis, G.M., Reesor, C.M. \& Astatkie, T. (2018). Striped bass early life history in the macrotidal Shubenacadie River. Transactions of the American Fisheries Society 147: 919-938. 
Dutton, J \& Gioia, K.A. (2019). Fecundity and embryonic development of spiny dogfish in the Northwest Atlantic Ocean. Transactions of the American Fisheries Society 148: 48-57.

Dyer, C., Wehrell, S. \& Daborn, G.R. (2005). Fisheries management issues in the upper Bay of Fundy. Acadia Centre for Estuarine Research Technical Report 80.

Ellis, J.E., Rowe, S. \& Lotze, H.K. (2015). Expansion of hagfish fisheries in Atlantic Canada and worldwide. Fisheries Research 161: 24-33.

Elson, P.F. (1964). Post-smolt Atlantic salmon in the Bay of Fundy. Pp. E20-E23 In. Hart, J.L. Fisheries Research Board of Canada, Biological Station. St. Andrews, NB. Annual Report and Investigators Summaries 1963-64: E-7.

FORCE. (Fundy Ocean Research Centre for Energy) (2009). Fisheries, landings and communities in Minas Basin. Appendix 9. www.fundyforce.ca/research.

FORCE. (2010). Fish surveys in Minas Channel 2010. Appendix H. www.fundyforce.ca/research.

FORCE. (2010). Oceanographic measurements: salinity, temperature, suspended sediment and turbidity, Minas Passage. August 2008 - September 2009. Appendix G. www.fundyforce.ca/research.

FORCE. (2017). Cape Sharp tidal venture. www.fundyforce.ca/technology.

Fuiman, L.A. (1977). Notes on the early development of the sea raven Hemitripterus americanus. Fishery Bulletin. 75: 467-470.

Garman, G.C. (1983). Observations on juvenile red hake associated with sea scallops in Frenchman Bay, Maine. Transactions of the American Fisheries Society 112: 212-215.

Garrett, C.J.R. (1972). Tidal resonance in the Bay of Fundy and Gulf of Maine. Nature 238: 441-443.

Gaskin, D.E., Read, A.J., Watts, P.F. \& Smith, G.J.D. (1985). Population dispersal, size and interactions of harbour porpoise in the Bay of Fundy and Gulf of Maine. Canadian Fisheries and Aquatic Sciences Technical Report 1291.

Gibson, A.J.F., Amiro, P.G. \& Robichaud-LeBlanc, K.A. (2003b). Densities of juvenile Atlantic salmon (Salmo salar) in inner Bay of Fundy rivers during 2000 and 2002 with reference to past abundance inferred from catch statistics and electrofishing surveys. CAFSAC Research Document 2003/121.

Gibson, A.J. \& Myers, R.A. (2002). Effectiveness of a high-frequency sound fish diversion system at the Annapolis tidal hydroelectric generating station, Nova Scotia. North American Journal of Fisheries Management 22: 770-784.

Gibson, A.J. \& Myers, R.A. (2003a). Biological reference points for anadromous alewife (Alosa pseudoharengus) fisheries in the Maritime region. Canadian Fisheries and Aquatic Sciences Technical Report 2468. 
Gill, A.B. (2005). Offshore renewable energy: ecological implications of generating electricity in the coastal zone. Journal of Applied Ecology 42: 605-615.

Gilmurray, M.C. \& Daborn, G.R. (1981). Feeding relations of the Atlantic silversides Menidia menidia in the Minas Basin, Bay of Fundy. Marine Ecology-Progress Series 6: 231-235.

Godin, G. 1968. The 1965 current survey of the Bay of Fundy. A new analysis of the data and an interpretation of the results. Marine Sciences, Energy, Mines and Resources Manuscript Report Ser 8.

Gordon, J. (1993). The woven weirs of Minas. Nova Scotia Department of Education, Curatorial Report 73.

Greenberg, D.A. (1984). A review of the physical oceanography of the Bay of Fundy.Canadian Fisheries and Aquatic Sciences Technical Report 1256: 9-30.

Greenberg, D.A. \& Amos, C.L. (1983). Suspended sediment transport and deposition modelling in the Bay of Fundy, Nova Scotia- a region of potential tidal power development. Canadian Journal of Fisheries and Aquatic Science 40 (Suppl. 1): 20-34.

Halliday, R.G. (1991). Marine distribution of the sea lamprey (Petromyzon marinus) in the Northwest Atlantic. Canadian Journal of Fisheries and Aquatic Science 48: 832-842.

Hammer, L. Eggertsen, L., Andersson, S., Ehnberg, J., Arvidsson, R., Gullstrom, M. \& Molander, S. (2015). A probabilistic model for hydrokinetic turbine collision risks: exploring impacts on fish. PLoS ONE 10(3): e0117756.

Hansen, L.P., Jonsson, N. \& Jonsson, B. (1993). Oceanic migration of homing Atlantic salmon, Salmo salar. Animal Behaviour 45: 927-941.

Hilton, E.J., Latour, R., Watkins, B. \& Rhea, A. (2011). Monitoring relative abundance of American shad in Virginia Rivers. 2010 Annual Report, Virginia Institute of Marine Science www.doi.org/10.21220/V5G314.

Hogans, W.E., Dadswell, M.J., Uhazy, L.S. \& Appy, R.G. (1993). Parasites of American shad, Alosa sapidissima (Ostreicththyes: Clupeidae) from rivers of the North American Atlantic coast and the Bay of Fundy, Canada. Canadian Journal of Zoology 71: 941-946.

Hoss, D.E. \& Blaxter, J.H.S. (1979). The effect of rapid changes of hydrostatic pressure on the Atlantic herring Clupea harengus L. 1. Larval survival and behaviour. Journal of Experimental Marine Biology and Ecology 41:75-85.

Huntsman, A.G. (1922). The fishes of the Bay of Fundy. Contributions to Canadian Biology 3: 49-72.

Huntsman, A.G. (1958). Shubenacadie salmon. Journal of the Fisheries Research Board of Canada 15: 1213-1218.

Iles, T.D. \& Sinclair, M. (1982). Atlantic herring: stock discreteness and abundance. Science (Washington, D.C.) 215: 627-633.

Imrie, D.M.G. \& Daborn, G.R. (1981). Food of some immature fish of Minas Basin, Bay of Fundy. Proceedings of the Nova Scotian Institute of Science 31: 149-153. 
Jessop. B. (1996). Eel fisheries in the Maritimes (Anguilla rostrata). Department of Fisheries and Oceans, Atlantic Fisheries Stock Status Report 96/14E.

Joyce, W., Campana, S.E., Natanson, L.J., Kohler, W.E., Pratt, H.L. \& Jensen, J.F. (2002). Analysis of stomach contents of the porbeagle shark (Lamna nasa) in the Northwest Atlantic. ICES Journal of Marine Science 59: 1263-1269.

Karsten, R.A., McMillan, J.M., Lickley, M.J. \& Hynes, R.D. (2008). Assessment of the current energy in Minas Passage, Bay of Fundy. Proceedings of the Institution of Mechanical Engineers, Part A. Journal of Power and Energy 222: 493-507.

Karsten, R., Swan, A. \& Culma, J. (2013). Assessment of arrays of instream tidal turbines in the Bay of Fundy. Philosophical Transactions of the Royal Society of Canada 371: 20120189.

Kendall, V.J., Stewart, P.L. \& Levy, H.A. (2018). Spatial and temporal delineation of ecological features of the Evangeline-Cape Blomidon-Minas Basin Ecologically and Biologically Significant Area (EBSA). Department of Fisheries and Oceans, Canadian Scientific Advisory Secretariat, Research Document 2018/013.

Ketchum, B.H. \& Keen, D.J. (1953). The exchanges of fresh and salt waters in the Bay of Fundy and Passamaquoddy Bay. Journal of the Fisheries Research Board of Canada 10: 97-124.

Keyser, F.M., Broome, J.E., Bradford, R.G., Sanderson, B. \& Redden, A.M. (2016). Winter presence and temperature related diel migration of striped bass Morone saxatilis in an extreme high flow passage in the Bay of Fundy. Canadian Journal of Fisheries and Aquatic Science 73: 1777-1786.

Knapp, L., Mincarone, M.M., Harwell, H., Polidoro, B., Sanciangco, J. \& Carpenter, K. (2011). Conservation status of the world's hagfish species and the loss of phylogenetic diversity and ecosystem function. Aquatic Conservation 21: 401-411.

Koeller, P. (1979). Distribution and movements of herring in the Bay of Fundy from juvenile surveys. CAFSAC Research Document 79/32.

Lacroix, G.L. (2008). Influence of origin on migration and survival of Atlantic salmon (Salmo salar) in the Bay of Fundy, Canada. Canadian Journal of Fisheries and Aquatic Science 65: 2063-2079.

Lacroix, G.L., Knox, D. \& Stokesbury, M.J. (2005). Influence of tidal flow on Atlantic salmon post-smolt migration and behavior in a coastal habitat. Journal of Fisheries Biology 66: 485-498.

Lacroix, G.L. \& McCurdy, P. (1996). Migratory behaviour of post-smolt Atlantic salmon during initial stages of seaward migration. Journal of Fisheries Biology 49: 1086-1101.

Lauzier, L.M. (1967). Bottom residual drift on the continental shelf area of the Canadian Atlantic coast. Journal of the Fisheries Research Board of Canada 24: 1845-1859. 
Leim, A.H. (1924). Life history of the shad \{Alosa sapidissima (Wilson)\} with special reference to the factors limiting its abundance. Contributions of Canadian Biology 2: 163-284.

Leim, A.H. \& Scott, W.G. (1966). Fishes of the Atlantic coast of Canada. - Fisheries Research Board of Canada Bulletin 155.

Logan-Chesney, L.M., Dadswell, M.J., Karsten, R.H., Wirgin, I. \& Stokesbury, M.J.W. (2018). Atlantic sturgeon Acipenser oxyrinchus surfacing behavior. Journal of Fish Biology 92: 929-943.

MacDonald, J.S., Dadswell, M.J., Appy, R.G., Melvin, G.D. \& Methven, D. (1984). Fishes, fish assemblages and their seasonal movements in the lower Bay of Fundy and Passamaquoddy Bay, Canada. Fisheries Bulletin 82: 121-139.

MacDonald, M. (1884). The shad-Clupea sapidissima. p. 594-607. In. The fisheries and the fisheries industries of the United States. G.B. Goode and Associates. $47^{\text {th }}$ Congress, $1^{\text {st }}$ Session Senate Misc. Doc. 124.

MacInnis, G.M. (2012). Spatio-temporal distribution of eggs and age-0 striped bass (Morone saxatilis) in the Shubenacadie River estuary. M.Sc. Thesis, Dalhousie University, Halifax, NS.

Markle, D.F., Methven, D.A. \& Coates-Markle, L.J. (1982). Aspects of spatial and temporal co-occurrence in the life history stages of the sibling hakes, Urophycis chuss (Walbaum 1792) and Urophycis tenuis (Mitchill 1815) (Pisces: Gadidae). Canadian Journal of Zoology 60: 2057-2078.

Martin, J.D. \& Dadswell, M.J. (1983). Records of coho salmon (Oncorhynchus kisuth, (Walbaum, 1792), in the Bay of Fundy and its tributary drainage. Canadian Fisheries and Aquatic Sciences Technical Report 776.

McCracken, F.D. (1963). Seasonal movements of the winter flounder Pseudopleuronectes americanus (Walbaum) on the Atlantic coast. Journal of the Fisheries Research Board of Canada 20: 551-586.

McKenzie, R.A. \& Tibbo, S.N. (1961). Herring movements in the Bay of Fundy and Gulf of Maine, 1957 and 1958. Journal of the Fisheries Research Board of Canada 18: 221-252.

McLean, M.F., Dadswell, M.J. \& Stokesbury, M.J.W. (2013). Feeding ecology of Atlantic sturgeon, Acipenser oxyrinchus oxyrinchus Mitchill, 1815 , on the infauna of intertidal mudflats of Minas Basin, Bay of Fundy. Journal of Applied Ichthyology 29: 503-509.

McLean, M.F., Simpfendorfer, C.A., Heupel, M.R., Dadswell, M.J. \& Stokesbury, M.J.W. (2014). Diversity of behavioural patterns displayed by a summer feeding aggregation of Atlantic sturgeon in the intertidal region of Minas Basin, Bay of Fundy, Canada. Marine Ecology - Progress Series 496: 59-69.

McMillan, J.L., Caissie, D., Marshall, T.J. \& Hinks, L. (2008). Population indices of brook trout (Salvelinus fontinalis), Atlantic salmon (Salmo salar), and salmon competitors in relation to summer water temperature and habitat parameters in 100 streams in Nova Scotia. Canadian Fisheries and Aquatic Sciences Technical Report 2819. 
Meister, A.L. (1984). The marine migration of tagged Atlantic salmon (Salmo salar L.) of USA origin. ICES CM 1984/M 27.

Melvin, G.D., Dadswell, M.J. \& Martin, J.D. (1986). Fidelity of American shad Alosa sapidissima (Ostreichthyes; Clupeidae) to its river of previous spawning. Canadian Journal of Fisheries and Aquatic Science 43: 640-646.

Melvin, G.D., Dadswell, M.J. \& McKenzie, J.A. (1992). The usefulness of meristics and morphometric characters in discriminating populations of American shad, Alosa sapidissima (Ostreichthys: Clupeidae) inhabiting a marine environment. Canadian Journal of Fisheries and Aquatic Science 49: 266-280.

Moore, T.M. (1998). Population characteristics of the spiny dogfish (Squalus acanthias Linneaus, 1758) from geographically distinct locations in Atlantic Canada during the summer of 1996. M.Sc. Thesis, Acadia University, Wolfville, NS.

Morantz, D.L. (1978). A review of existing information of the fisheries of the Shubenacadie-Stewiacke River basin. Shubenacadie-Stewiacke Basin Fisheries Research Technical Report 1.

Moyle, P.B. \& Cech, J.J. (1996). Fishes: an introduction to ichthyology. Prentice - Hall, NJ, USA.

Neves, R.J. (1981). Offshore distribution of alewife, Alosa pseudoharengus, and blueback herring, Alosa aestivalis, along the Atlantic coast. Fisheries Bulletin 79: 473-485.

Nielsen, J., Hedeholm, R.B., Heinemeir, J., Bushnell, P.G. \& Christian, J.S. (2016). Eye lens radiocarbon revels centuries of longevity in the Greenland shark (Somniosus microcephalus). Science 353: 702-704.

Parker, M., Westhead, M. \& Service, A. (2007). Ecosystem overview report for Minas Basin, NS, Fisheries and Oceans Canada, Oceans Habitat Report 2007-05.

Parramore, L.M. \& Rulifson, R.A. (2001). Dorsal coloration as an indicator of different life history patterns for striped bass within a single watershed of Atlantic Canada. Transactions of the American Fisheries Society 130: 663-674.

Pearson, N.J., Gingras, M.K., Arimitage, I.A. \& Pemberton, S.G. (2007). Significance of Atlantic sturgeon feeding excavations, Mary's Point, NB, Canada. PALAIOS 22: 457-464.

Perley, M.H. (1852). Reports on the sea and river fisheries of New Brunswick, $2^{\text {nd }}$ ed. Queens Printer, Fredericton, NB.

Peterson, R.H., Johansen, P.H. \& Metcalfe, J.L. (1980). Observations on early life stages of Atlantic tomcod, Microgadus tomcod. Fisheries Bulletin 78: 147-158.

Piers, H. (1934). Accidental occurrence of the man-eater or great white shark Carcharodon carcharias (Linn.) in Nova Scotian waters. Proceedings of the Nova Scotian Institute of Science 18: 192-203.

Prince, E.E. (1912). The shad fishery of Canada and its restoration. Sea fisheries of eastern Canada. Canada Commission of Conservation p. 120-136. 
Quinn, D. (2010). Characteristics of the smolt migration of Atlantic salmon (Salmo salar) in the Gaspereau River, NS. Honours Thesis, Acadia University, Wolfville, NS.

Redden, A.M., Stokesbury, M.J.W., Broome, J.E., Ketser, F.M., Gibson, A.J.F., Halfyard, E.A., McLean, M.F., Bradford, R., Dadswell, M.J., Sanderson, B. \& Karsten, R.A. (2014). Acoustic tracking of fish movements in the Minas Passage and FORCE demonstration area: preturbine baseline studies (2011-2013). Acadia Centre Estuarine Research Technical Report 118.

Rees, M. (2016). White shark one year later. The Shoreline Journal. August 2016: 21.

Reid, P.R. (1982). Aspects of the winter ecology and behaviour of bald eagles (Haliaectus leucocephalus alaseanus Townsend) on the Shubenacadie River, NS. M.Sc. Thesis, Acadia University.

Roberts, L.A. (1987). Spatial and temporal distributions of the larvae of herring (Clupea harengus L.) and rainbow smelt (Osmerus mordax Mitchill) in Minas Basin, NS. Honours thesis, Acadia University, Wolfville, NS.

Rulifson, R.A. \& Dadswell, M.J. (1995). Life history and population characteristics of striped bass in Atlantic Canada. Transactions of the American Fisheries Society 124: 477-507.

Rulifson, R.A. \& Dadswell, M.J. (2020). Alewife and blueback herring captured by intertidal weirs in the inner Bay of Fundy, Canada display seasonal demographics that suggest multiple migrating stocks. Marine and Coastal Fisheries (in press).

Rulifson, R.A., McKenna, S.A. \& Dadswell, M.J. (2008). Intertidal habitat use, population characteristics, movement, and exploitation of striped bass in the inner Bay of Fundy, Canada. Transactions of the American Fisheries Society 137:23-32.

Rulifson, R.A., McKenna, S.A. \& Gallager, M.L. (1987). Tagging studies of striped bass and river herring in the upper Bay of Fundy, NS. Institute of Coastal Marine Research Technical Report 82-02. East Carolina University, Greenville, NC, USA.

Rulifson, R.A. \& Tull, K.A. (1998). Striped bass spawning in a tidal bore river: the Shubenacadie estuary, Atlantic Canada. Transactions of the American Fisheries Society 128: 613-624.

Sanderson, B.G. \& Redden, A.M. (2015). Perspective on the risk that sediment-laden ice poses to in-stream tidal turbines in Minas Passage, Bay of Fundy. International Journal of Marine Energy 10: 52-69.

Sandru, M. (2011). World's biggest tidal power plant opened in South Korea. Wave Power. www.greenoptimistic.com/korea-biggest-tidal-power-plant.

Saunders, R.L. (1969). Contributions of salmon from the northwest Miramichi River, NB, to various fisheries. Journal of the Fisheries Research Board of Canada 26: 269-278. 
Scott, J.S. (1987). Matrices of co-occurrences of fish species on the Scotian Shelf and in the Bay of Fundy. Canadian Fisheries and Aquatic Sciences Technical Report 1581.

Scott, J.S. (1988). Seasonal spatial distribution of groundfish of the Scotian Shelf and the Bay of Fundy 1974-79 and 1980-84. Canadian Fisheries and Aquatic Sciences Technical Report 1853. 81 p.

Scott, W.B. \& Scott, M.G. (1988). Atlantic Fishes of Canada. Canadian Bulletin of Fisheries and Aquatic Sciences 219. 731 p.

Scully, B.W. (1983). The utilization of an intertidal salt-marsh-mudflat system as a nursery area by smooth flounder Liopsetta putnami (Gill). M.Sc. Thesis, Acadia University, Wolfville, NS.

Simon, J.E. \& P.A. Comeau. (1994). Summer distribution and abundance trends of species caught on the Scotian Shelf from 1970-92, by the research vessel groundfish survey. Canadian Fisheries and Aquatic Sciences Technical Report 1953.

Stevenson, C.H. (1898). The restricted inland range of shad due to artificial obstructions and its effects on natural reproduction. Bulletin of the United States Fisheries Commission 17: 265-271.

Stokesbury, K.D.E. \& Dadswell, M.J. (1989). Seaward migration of juvenile alsoids from an estuary in Atlantic Canada. Canadian FieldNaturalist 103: 338-393.

Stokesbury, K.D.E. \& Dadswell, M.J. (1991). Mortality of juvenile clupeids during passage through a tidal, low-head hydroelectric turbine at Annapolis Royal, NS. North American Journal of Fisheries Management 11: $149-154$.

Stokesbury, M.J.W., Logan-Chesney, L.M., McLean, M.F., Buhariwalla, C.F., Redden, A., Breadsall, J.W., Broome, J.E. \& Dadswell, M.J. (2016). Atlantic sturgeon spatial and temporal distribution in Minas Passage, NS: a region of future tidal energy extraction. PLoS ONE 11: e0158387.

Stokesbury, M.J.W. \& Stokesbury, K.D.E. (1993). Occurrence of juvenile Atlantic menhaden, Brevoortia tyrannus, in the Annapolis River, NS. Estuaries 16: 827-829.

Stone, H.H. (1985). Composition, morphological characteristics and feeding ecology of alewifes (Alosa pseudoharengus) and blueback herring (A. aestivalis) (Pisces: Clupeidae) in Minas Basin. M.Sc. Thesis, Acadia University, Wolfville, NS.

Stone, H.H. \& Daborn, G.R. (1987). Diet of alewifes, Alosa pseudoharengus and blueback herring, A. aestivalis (Pisces: Clupeidae) in Minas Basin, NS, a turbid, macrotidal estuary. Environmental Biology and Fisheries 19: 55-67.

Taylor, A.D., Kyoko, O., Sheng, J. \& Litvak, M.K. (2016). Oceanic distribution, behavior, and a winter aggregation area of adult Atlantic sturgeon, Acipenser oxyrinchus oxyrinchus, in the Bay of Fundy. PloS ONE 11(4): e0152470.

Tee, K-T. (1975). Tide-induced residual current in Minas Channel and Minas Basin. Ph.D. Thesis, Dalhousie University, Halifax, NS. 
Templeman, W. (1963). Distribution of sharks in the Canadian Atlantic. Bulletin of the Fisheries Research Board of Canada 140. 77 p.

Themelis, D.E. (1986). Feeding ecology of American shad, Alosa sapidissima, in the upper and lower Bay of Fundy, Canada. M.Sc. Thesis, Acadia University, Wolfville, NS.

Tibbo, S.N. \& Humpreys, R.D. (1966). An occurrence of capelin (Mallotus villosus) in the Bay of Fundy. Journal of the Fisheries Research Board of Canada 43: 463-467.

Tobey, A. (1977). Shrimp midwater trawl development 1976 Gulf of St. Lawrence. Department of Fisheries and Environment, Fisheries and Marine Service Technical Report 701.

Tollit, D., Wood, J., Broome, J. \& Redden, A. (2011). Detection of marine mammals and effects monitoring at the NSPI (Open Hydro) turbine site in Minas Passage during 2010. Acadia Centre for Estuarine Research Technical Report 101.

Towse, K. (2014). The Scott's Bay tidal Power project: a new approach to tidal power. www.halcyontidalpower.com/projects.

Trippel, E.A., Morgan, M.J., Fréchet, A., Rollet, C., Sinclair, A., Annad, C., Beanlands, D. \& Brown, L. (1997). Changes in age and length at sexual maturity of Northwest Atlantic cod, haddock and pollock stocks, 1972-1995. Canadian Fisheries and Aquatic Sciences Technical Report 2157.

Viehman, H.A. \& Zydlewski, G.B. (2015). Fish interactions with a commercial scale tidal energy device in the natural environment. Estuaries and Coasts 38 (Suppl. 1): 241-252.

Von Raben, K. (1957). Regarding the problem of mutilation of fishes by hydraulic turbines. Die Wasserwirtschaft 4: 97-100. Fisheries Research Board of Canada, Translation Series 448.

Waldman, J., Hasselman, I.D., Bentzen, P., Dadswell, M.J., Maceda, L. \& Wirgen, I. (2014). Genetic mixed stock analysis of American shad at two Atlantic coast locations: Delaware Bay and the inner Bay of Fundy. N.A. North American Journal of Fisheries Management 34: 1190-1198.

Walters, R.A., Tarbotten, M.R. \& Hiles, C.E. (2013). Estimation of tidal power potential. Journal of Renewable Energy 51: 255-262.

Wehrell, S. (2005). A survey of the groundfish caught by the summer trawl fishery in Minas Basin and Scots Bay. Honours Thesis, Dept. of Biology, Acadia University, Wolfville, NS.

Wehrell, S., Dadswell, M.J. \& Redden, A. (2008). Population characteristics, movements and a population estimate of Atlantic sturgeon (Acipenser oxyrinchus) in Minas Basin, Bay of Fundy during the summer of 2007. Acadia Centre for Estuarine Research Technical Report 90.

Whidden, J.A. (2015). Population demographics and species identification of two at risk skates: little shark Leucoraja erinacea and winter skate Leucoraja ocellata in Minas Basin, Bay of Fundy. M.Sc. Thesis, Acadia University, Wolfville, NS. 
Williams, P.J. (1985). Use of otoliths for stock differentiation of American shad Alosa sapidissima Wilson. M.Sc. Thesis, Acadia University, Wolfville, NS.

Wirgin, I. Jessop, B., Courtenay, S., Pederson, M., Maceda, S. \& Waldman, J.R. (1995). Mixed stock analysis of striped bass in two rivers of the Bay of Fundy as revealed by mitochondrial DNA. Canadian Journal of Fisheries and Aquatic Science 52: 961-970.

Wirgin, I., Maceda, L., Waldman, J.R., Wehrell, S., Dadswell, M.J. \& King, T. (2012). Stock origin of migratory Atlantic sturgeon in the Minas Basin, inner Bay of Fundy, Canada. Transactions of the American Fisheries Society 141: 1389-1398.

Won, S.O. (1980). Korea tidal power study-1978. Science Report, Taiwan University 11: 32-39.

Zangiabadi, E., Masters, L., Williams, A.J., Croft, T.N., Malki, R., Edmunds, M., Mason-Jones, A. \& Horsfall, I. (2016). Computational prediction of pressure change in the vicinity of tidal stream turbines and consequences for fish survival rate. Journal of Renewable Energy 101: 1141-1156. 
